Elsevier Editorial system(tm) for Lithos Manuscript Draft

Manuscript Number: LITHOS6288R1

Title: The Amphiboles of the REE-rich A-type peralkaline Strange Lake pluton - Fingerprints of magma evolution

Article Type: Regular Article

Keywords: Amphibole, REE, Strange Lake, Peralkaline granite, Magma evolution

Corresponding Author: Miss Karin Siegel, M.Sc.

Corresponding Author's Institution: McGill University

First Author: Karin Siegel

Order of Authors: Karin Siegel; Anthony E Williams-Jones, Ph.D.; Vincent J van Hinsberg, Ph.D.

Abstract: Major and trace element compositions of amphibole in igneous environments commonly reflect evolving magma compositions. In this study, we use the amphibole-group minerals from the strange Lake, REE-enriched peralkaline granitic pluton to gain insights into the evolution of the magma. This 1240 Ma old pluton consists of two main intrusive facies, an early hypersolvus granite, which occurs as separate northern and southern intrusions, and a more evolved transsolvus granite. In the hypersolvus granite the amphibole is a late interstitial phase, whereas in the transsolvus granite, it is present as phenocrysts. The amphibole compositions vary from calcic-sodic (ferro-ferri-katophorite) in the southern hypersolvus granite to sodic (arfvedsonite, ferro-ferrileakeite) in the other, more evolved granitic units. High Na, Si, Li, and low $\mathrm{Al}$ and $\mathrm{Ca}$ concentrations in the amphibole phenocrysts of the transsolvus granite indicate formation from a more evolved magma compared to the hypersolvus granite, despite the fact that these crystals formed early. We interpret the increasing Fe3+/Fe2+ ratios in the amphibole of the hypersolvus granite to reflect crystal chemical effects (Na/Ca-ratio) and increasingly oxidizing conditions in the magma, whereas in the phenocrysts of the transsolvus granite, the increasing ratio was the product of increasing proportions of $\mathrm{F}-$ and $\mathrm{OH}-$ in the melt. The amphiboles of all the granite units have elevated Nb, Zr, Hf and REE concentrations compared to the bulk rock, suggesting that these elements are compatible in amphibole. By contrast the much lower Ti concentration was due to saturation of the magma in sodium-titanosilicates. The amphibole REE concentrations vary greatly among the granite units. Amphibole of the southern and northern hypersolvus granite contains 0.16 and 0.07 wt. $\% R E E+Y$, on average, respectively, and in the transsolvus granite, the average $\sum R E E$ content is only 0.01 wt. $\%$, despite the more evolved nature of its host transsolvus granite. We intrepret this compositional difference to be due to the fact that the latter represents phenocrysts, which crystallised early, whereas the hypersolvus arfvedsonite is a late interstitial phase. Chondrite-normalized REE profiles emphasise the wide range in LREE-, and the narrow range in HREEconcentrations of the amphiboles. The variations in the LREE-profiles reflect the variable crystallization of primary LREE-bearing phases, 
including monazite-(Ce), pyrochlore group minerals and gagarinite-(Ce), prior to or contemporaneous with the amphibole, as well as the exsolution of a LREE-rich fluoride melt. The LREE are incompatible in the amphibole structure (apparent $\mathrm{D}<0.01$ ) and are preferably accommodated by the octahedral C-site, whereas the HREE occupy the B-site. The chondritenormalized HREE profiles are steep and display an increasing relative enrichment that culminates in compatible behavior for Yb and Lu (apparent $D>1$ ). Owing to their small ionic radius and their compatibility with the amphibole structure, HREE concentrations were more controlled by partitioning (crystal chemical effects) than by the concentrations in the corresponding magma. Large proportions of the bulk HREE content (up to 70 o) reside in the amphibole, and their later release through hydrothermal replacement helps to explain the extreme and unusual HREE enrichment of the Strange Lake pluton. 


\section{RESPONSE TO EDITOR AND REVIEWERS}

We are encouraged that Editor Nelson Eby and the two reviewers consider our manuscript merits publication after moderate revision. Below, we systematically address the minor points raised by the editor and reviewer \#1, and then the more specific points raised by reviewer \#2.

\section{EDITOR COMMENTS}

1) Sections need to be numbered.

Sections have been numbered.

2) Line 23 - NEVER cite "in prep" in a manuscript. Citation found in a number of places. Remove.

Citations removed.

3) Starting on line 229, multiple repeats of the same line. Same problem starting on line 247.

Repetitions removed

4) How was the Fe2+/Fe3+ ratio calculated.

The ratio was calculated from apfu numbers, which were obtained from the formula calculations.

5) Tables 2 - 5 - better to give all the analyses in supplemental data tables rather than averages which are essentially useless information.

We have added values for the median and median absolute deviation to the tables to address this concern and provided the full dataset in supplemental tables.

6) Mayer et al. reference incomplete.

Reference corrected. 


\section{REVIEWER \#1}

\section{General comments of reviewer \#1:}

The manuscript is well written, data are of high quality and results are supported by data. Discussion is rigorous and methods are correct. In general, the manuscript does not bring much new knowledge on amphibole crystal chemistry and on magma evolution in peralkaline systems. However, I consider the manuscript an important contribution for the international scientific community and worth to be published in Lithos because it is a positive attempt to link amphibole crystal chemistry to igneous evolution of peralkaline melts. The manuscript is probably too long and would benefit, in order to increase its readability, of a significant shortening. I thus suggest to the authors to operate a shortening of the text in all sections. The number of figures is also excessive and should be shortened (figure 6, 9, 10, 11 a for example are not strictly necessary). I consider the manuscript worth of publication after minor to moderate revision.

We have been able to make a minor reduction in the overall length of the manuscript and have removed Figures 9 and 11a. However, we consider Figure 6 and 10 necessary to support our conclusions. The figure numbers have been adapted (new total of 15 figures).

The authors should also consider to revise the conclusions based on the core to rim variations observed in amphibole phenocrysts because the trends they describe are in most cases very poorly constrained. For most of the elements there is complete overlap between core and rim.

We disagree. Although there is some overlap between core and rim concentrations, there is still an obvious trend to more evolved compositions (see Fig. 6 and Table 5) in the phenocryst rims.

\section{Additional comments}

Line 23. Remove this sentence because it refers to a paper in progress.

The first part of the sentence was removed. However, the second part is necessary in order to provide a quick overview of the main findings of the study.

Line 65-66. Remove this sentence because it refers to a paper in progress.

Sentence deleted.

Line 168. Remove this sentence because it refers to a paper in progress.

Sentence deleted.

Lines 225-243. Check repetitions.

Repetitions deleted.

Lines 248-263. Check repetitions. 
Repetitions deleted.

Lines 482-486. Remove this sentence because it refers to a paper in progress.

The first part of the sentence was removed.

Lines 488-489. This sentence is generic. In Ca-amphiboles Ti is generally compatible, the authors should specify which system they are referring to.

Sentence rephrased.

Line 514. Remove reference to work in progress.

Reference removed.

Line 532. "in" not necessary

Word removed.

Lines 614-615. This sentence should be better explained. In general, with the increasing of melt evolution (polymerization) network modifiers elements (such as REE) become more compatible in amphibole. Here authors suggest the opposite.

Sentence rephrased.

Lines 623-625. Not clear conclusion I suggest to remove this sentence.

The sentence is needed to provide linkage to the next paragraph. It has been rephrased, however, in order to make our point more clearly.

Lines 703-705. How quenching can modify the REE incorporation? More details are needed or the sentence should be removed.

The first part of the sentence was removed. 


\section{REVIEWER \#2}

\section{General comments of reviewer \#2:}

I enjoyed reading this paper, which is well-written, but would like to have seen more context for your research, including more discussion of previous work and more clearly-developed science questions. I am surprised by the introduction of different granite terminology from all previous workers with no real explanation as to why you have made the change, and I would like to see some more petrographical descriptions to underpin the mineral chemistry.

These concerns are all addressed in the course of the following section.

\section{Specific comments}

Introduction, general: I agree that an extensive introduction to the REE as critical metals is not needed here, because the literature on this is pretty voluminous. However, I would like to see a few sentences explaining the economic value of the REE (and $\mathrm{Nb}$ and $\mathrm{Zr}$ ) and something about the wider distribution and types of deposits, with some relevant references. This seems particularly appropriate as the project has been sponsored by Quest Rare Minerals.

We disagree. The focus of this manuscript is the nature of amphiboles from alkaline systems and their ability to host some of the HFSE rather than the economic value of the REE in general. Moreover, publications by our group have provided this information for Strange Lake, e.g., Gysi et al. (2016) published in the journal Economic Geology.

Intro, line 18: I find the phrase 'This magma ultimately produced a large REE/HFSE resource' a bit odd, partly because hydrothermal fluids that may or may not have been derived from the magma played quite a significant role in the formation of the Strange Lake deposit. I'd suggest rewording.

Sentence rephrased.

Intro, line 19: Resources are most commonly described in terms of total rare earth oxides TREO (or in the case of Strange Lake, TREO + Y) - or sometimes as RE2O3. Not REEO3 please - this is incorrect.

Corrected.

Intro, line 21: You are referring to the current study, so I think you mean 'are used' not 'were used'. I was somewhat confused at first by this paragraph, which jumps from the results of this study, to published resource data, and then back to this study. Make sure your own work is distinct from previously published work.

Sentence rephrased. 
Intro, line 23: Throughout the paper you refer to Siegel et al. (in prep) - please don't do this, as it is not a reference that the reader will be able to find. Remove all references to papers in prep the current paper should be able to stand on its own, as you are publishing it first.

Reference removed.

Background, line 33: Note spelling of riebeckite

Corrected.

Background, line 51-52: Please cite some other papers here describing Strange Lake. Where were the different granites first described?

The words 'this study' were added to the sentence in order to clarify that the division of the hypersolvus granite into two units and the occurrence of a transsolvus granite (instead of subsolvus granite as described in earlier studies) are the result of this study and Siegel et al. (in prep.).

Background, line 55: I don't agree with the suggestion that the high concentration of REE in these pegmatites is rarely observed elsewhere. There are many magmatic-hosted REE deposits, some associated with pegmatites Ambohimirahavavy in Madagascar and Tamazeght in Morocco are some examples of alkaline intrusions with REE-enriched pegmatites. Please make sure you cite references for some of the other extensive research in similar magmatic-hydrothermal systems.

We are aware that there are other highly REE enriched magmatic-hydrothermal deposits. However, as the focus of the manuscript is the amphibole chemistry, we only cited work that uses amphibole compositions for understanding the deposit evolution. Also, Strange Lake is special because of its extreme HREE enrichment, something that is rarely observed elsewhere.

Background, line 64 "which accumulated in the highly evolved residual melts" - it's not clear what you are referring to here.

Clarified.

Intro and background, general: So much has already been written about Strange Lake and especially the interaction of magmatic and hydrothermal processes to generate the alteration, that I think you should state very clearly in this section why it is also important to study the magmatic minerals, and what questions you aim to answer in this work. This might only be a couple of sentences, but I think it would strengthen the paper.

We believe that we have addressed the importance of the amphibole study, which is clearly explained in lines 15 onwards. 
Geologic setting, line 76-82: Could this background geology be shown on Fig 1, for example the extent of the Nain Plutonic Suite on the inset?

This would require an additional figure, as the Nain Plutonic Suite is too small to be visible on the inset in Fig. 1. Thus, Gower and Krogh, (2002) and Miller (1996) are cited where Strange Lake is shown in the context of the NPS.

Geologic setting, line 83: 'is hosted by' is ambiguous - do you mean 'intrudes'?

Rephrased.

Geologic setting, line 84: It would be nice to see reference here to some of the more recent research in the area, such as the Misery syenite for example, to give more context.

A reference to the Misery Lake intrusion has been added.

Geologic setting, line 90: again, 'other host' is unclear; wording such as 'country rock for the northern part of...' would be better

Rephrased.

Geologic setting, line 96: On what basis is it known to be the earliest phase of the pluton? Cite a reference. Overall this section needs more references, as you are describing previous work.

Reference added. Most of information on the Strange Lake pluton given in this section was gathered during the course of this study.

Geologic setting, line 98: On the map it looks like the central and southern part of the pluton, not just the central part

Rephrased.

Geologic setting, line 102: How small is small? 1m, 100m, $1 \mathrm{~km}$ ?

This is not possible to define as there is very limited outcrop. The word 'smaller' refers to the previous sentence 'occupies the major part of the pluton'.

Geologic setting, line 105-106: Is this porphyritic granite shown on Fig. 1? I wonder if it might be the area shown as 'quench zone'? Make sure the map and text match

The term 'quench zone' has been replaced by 'dark grey granite' in Fig. 1.

Strange Lake Pluton, general: I compared your Fig. 1 with the map in Vasyukova and WilliamsJones 2016 and was surprised to see that the map is the same but the key is different. Your map indicates that most of the pluton is transsolvus granite, whilst hers shows it as subsolvus granite. A bit more checking shows that Gysi and Williams-Jones (2013) used a different map, but again 
had the largest area as subsolvus granite, as did Salvi and Williams-Jones (2006), Boily and Williams-Jones (1994) - and all other workers. You may disagree with them all and have very good reasons for using a different classification of the granites, but you should explain why, and cite their work.

A clarification and citation of previous work was added to the text.

The terminology of the granite units was revised during the course of this study based on a careful petrological examination. A manuscript that explains new granite definitions is about to be submitted for publication.

Geologic setting, line 110-111: Divided by who? Is this your work? If so, make it clear that this subdivision is part of this study. If not, cite a reference. Note that by definition granite cannot be fine-grained - are you referring to a microgranite (medium-grained)? Please clarify this.

The subdivision is part of this study (clarified in text).

The term granite has been replaced by microgranite.

Geologic setting, line 124: What forms remnants in what?

Sentence rephrased.

Geologic setting, line 127: Try to ensure that your figures appear in the order they are referenced in the text - so $2 d$ should not be referenced before $2 c$.

Figures $2 \mathrm{c}$ and $\mathrm{d}$ have been exchanged in the figure and text.

Geologic setting, line 138: What size are these enclaves? cm-scale, m-scale or larger? What are they made of, and what is the nature of their contacts? Either provide more description, or cite a reference in which they are described.

A more detailed description of the appearance of the enclaves was added. Their mineralogical composition had been described previously in line $177 \mathrm{ff}$.

Transsolvus granite, general: As mentioned above, most other workers distinguished a subsolvus granite which was highly altered, but lacked perthitic feldspar. You have used different terminology, implying that perthitic feldspar is present throughout the intrusion, and that there is an unaltered hypersolvus granite in the central part which becomes progressively more altered outwards. However the reason for this different terminology is not clearly described or explained, and in the section on the transsolvus granite it is not clear which parts of the description apply to the fresher core and which to the more altered part. This descriptive section really needs to be rewritten which reference to previous work, and a clear explanation of where and why your subdivisions of the pluton diverge from those of other workers. 
See response to comment 'Strange Lake Pluton, general'

Geologic setting, line 163-173: Where is this porphyritic granite? It is not shown on Fig. 1. Is the intruding transsolvus granite part of the main transsolvus granite or something different? Please clarify as part of the rewrite of this section. Note that the enclaves should be described where they are first introduced.

The term quench zone in Figure 1 has been replaced by dark porphyritic microgranite. The description of the enclaves has been expanded.

Methods, material: It would be helpful if sample numbers were added to Fig. 1. I note that only averages are presented in the tables, but would suggest that the full datasets are made available as supplemental data. I would prefer to see a little more information about when the bulk-rock samples were analysed, what methods were used - is this sodium peroxide or lithium metaborate fusion? - and what QC was done (duplicate analyses etc.)

The full datasets are now reported as supplemental data. We have also added the median and median absolute deviation (mad) for the bulk rock and amphibole analyses (Tables 1,4)

We consider the analytical information provided for the bulk rock analysis as sufficient.

Results, general: This section starts straight into the details of amphibole chemistry, with no description of the petrography of the samples that you are working on. You have studied a lot of samples, and whilst there is some general overview in the geologic setting section, it would be useful to give a brief petrographical summary of the actual samples that have been analysed, which will make the mineral chemistry easier to understand. For example, petrographic differences between the fine-grained and pegmatitic/oikocrystic variants of the southern hypersolvus granite have not been described in the geologic setting.

We consider that descriptions of the samples used in the study would unnecessarily lengthen the manuscript. All the granite types are described petrographically in the section 'geologic setting'. We have, however, added a more detailed description of the pegmatitic/oikocrystic samples of the southern hypersolvus granite in the geologic setting.

Results, line 224-243: In the pdf that I received, these lines are simply a continuous repeat of the references. This may be a problem in pdf creation, but needs to be checked. Lines 247-263 are the same.

Repetitions removed.

Results, line 284-286: What about tables 2 and 4? Tables should be numbered in the order they are cited in the text. You have presented whole-rock data for your samples but they are not separately described in the results section, and the major element data are not discussed at all. I 
would recommend adding a brief stand-alone description of these data to provide context for the mineral chemistry.

A separate description of the major and trace element compositions of the samples used in this study was added in the results section (5.1). The table numbers have been adjusted and now appear in the order that they are cited in the text.

Results, line 291-292: You might want to state that here you have alkali feldspar phenocrysts, so it's a reasonable assumption that alkali feldspar fractionation was the main control - and so lower Al amphiboles are more evolved. It may seem obvious to you, but it can be useful to make the basis for your assumptions clear.

Information added as recommended.

Results, line 327: You haven't mentioned F (fig. 5h).

A statement on amphibole fluorine contents was added.

Results, line 328-337: Why did you choose to only plot cores and rims for the transsolvus granite - because this is the only unit with zoned phenocrysts? How large are these amphiboles? You state in the geologic setting that they form prismatic phenocrysts, but as mentioned above you have not described your samples in detail. A summary of basic petrographical information is necessary to underpin the mineral chemistry. Also note that on Fig. 6 core-rim pairs from the same crystal are not identified, so it is difficult to see if there is systematic variation. You might want to consider whether this would be useful.

Indeed the transsolvus granite is the only unit with amphibole phenocrysts. The size of these phenocrysts can be estimated from Figures $2 \mathrm{c}$ and $3 \mathrm{c}$. We consider our sample description to be sufficient; additional description would unnecessarily extend the length of the manuscript.

The display of core-rim pairs for individual samples in Fig. 6 was considered, however too few analyses were performed to enable showing the differences within a sample. We consider that the displayed core-rim differences are sufficient to make the point that the rims are more evolved than the cores.

Results, line 344: 'average' - is this the mean value? I would guess so but it should be stated. It is interesting that the amphiboles in the fine-grained southern hypersolvus granite seem to be major contributors for the bulk-rock REE whereas in other variants other REE minerals are likely more important. As above, a petrographical description of the different variants, including discussion of their REE mineralogy, is needed to provide context here.

The 'average' is the median value, and this has been added in the text. As stated above, a detailed petrographical description of the granite variants is provided in the 'geologic setting' section. 
Results, line 368: I'm not convinced by 'conspicuous exceptions' here. At least some of the rock types mentioned contain pyrochlore group minerals and zircon, and these would certainly accommodate $\mathrm{Nb}, \mathrm{Zr}$ and $\mathrm{Hf}$. Again, this discussion needs to be linked more clearly to the petrography of the analysed samples. In general, it looks as though the amphibole may be the major hosts of many trace elements in the southern hypersolvus granites, but less so in all other variants.

We agree that most of the $\mathrm{Nb}, \mathrm{Zr}$ and $\mathrm{Hf}$ is preferentially accommodated by zircon, monazite(Ce) and the pyrochlore group minerals at Strange Lake. The sentence has been modified accordingly. The 'conspicuous exceptions' statement is only to point out that the amphibole is also an important host for these elements in all granite units (see Figs. 7 b, d, f).

Results, line 379: If you are going to discuss lithium it should also be included in the figures.

The lithium (vs. Fe3+) content is displayed in Figure 11 (former Fig. 12).

Results, line 383: As individual samples are neither plotted for Li nor included in the table, there is no evidence for the extensive variation between different samples and crystals, except the fact that errors (presumably representing the range of values) are large. Plotting Li would help with this, as would including the full dataset as supplemental data.

As stated above, the lithium (vs. $\mathrm{Fe}^{3+}$ ) content and its distribution among granite units is displayed in Figure 11 (former Fig. 12).

Discussion, line 399: Ferro-ferri-katophorite has only been described in the southern hypersolvus granite but is important for its high REE concentrations and seems to be the main REE-bearing mineral in this granite type, yet is only mentioned here as "minor (fluoro)katophorite" - it would be very useful to see some clearer discussion of modal abundances of the different amphiboles in the rock.

Determining the modal abundances of the different amphibole is effectively impossible because they can only be distinguished on the basis of electron microprobe analyses. We have added the number of analyses (n) for each amphibole type measured per granite unit in the text.

Discussion, line 439: Please quote some of the many references giving evidence for exsolution of a hydrous fluid, for example the papers of Salvi and Williams-Jones. The existing models for the evolution of the Strange Lake pluton and mineral deposit should have already been discussed in more detail in the geologic setting section.

References have been added.

Discussion, line 445: What is the evidence that the enclaves represent the quenched margin of the transsolvus granite?

The sentence has been replaced by a more accurate and data-supported statement. 
Discussion, line 459-460: Here you suggest a progressive change from the southern to the northern hypersolvus granite, but in line 428-429 you suggested that they are derived from separate magma batches. Certainly they are chemically quite different. It would be useful to include some discussion of their likely relationship - cogenetic or not? to provide context for the detailed chemistry.

The northern and southern hypersolvus granites do, indeed, represent two separate magma batches. The sentence has been changed accordingly.

Discussion, line 475-476: Here you say that the amphibole in the transsolvus granite occurs as phenocrysts, therefore crystallised too deep to have experienced fluid exsolution. However in line 438 you note depleted $\mathrm{Na}$ in the rims of these phenocrysts and suggest that this is due to fluid exsolution. These two statements seem to me to be contradictory and to need rethinking. Looking back at some published papers (e.g. Salvi \& Williams-Jones 2006), I note that fluid exsolution is likely to have occurred below the temperatures of amphibole crystallisation, but to have caused alteration of amphiboles including Na-depletion - it would be useful for you to consider this previous work in your discussion.

We agree that the two statements contradict each other. We have rephrased the statements in both sections based on recent research indicating that the amphibole rims may have continued to crystallize after emplacement, during which the magma experienced degassing and oxidation.

Discussion, line 500: It's not entirely clear to me what has been done here - in line 495 you suggest that you used a spreadsheet to estimate the proportion of amphibole in each unit; is the 14 wt\% amphibole mentioned in line 500 based on the calculations in this spreadsheet, or is it based on actual estimation from your thin sections? If the former, was it checked with the real samples? I may have misunderstood, in which case my apologies, but I think this could be written a bit more clearly.

The proportion of 14 wt. \% amphibole is based on calculations using the MINSQ spreadsheet mentioned in line 500, and is in good agreement with visual estimates of several thin sections $(\sim 15$ wt. \%).

Discussion, line 548: You might want to make reference to, or comparison with the Pitinga raremetal deposit, which is very similar to Strange Lake but even more lithium-enriched.

Although the Pitinga rare metal deposit may be lithium enriched, no study of the lithium content of the amphibole of this deposit has been reported and thus there seems no reason for referring to this deposit.

Discussion, line 624: It seems likely that as the magma evolved, another phase began to crystallise that preferentially incorporated the REE, for example allanite or monazite? The REE would be more compatible in this phase than in amphibole, thus leading to lower contents in 
amphibole in all but the earliest hypersolvus granite. Ah - I see that you actually state this in line 689 - it might be worth proposing this earlier?

We consider that the issue has been addressed sufficiently.

Discussion, line 664-667: As you establish in the next paragraph, amphibole typically contains $<10 \%$ of the bulk-rock REE - perhaps not the 'significant proportion' stated here?

We disagree, the amphibole hosts up to $70 \mathrm{wt} . \%$ of the bulk HREE in some units.

Conclusions, general: Overall the conclusions are good, and well-developed from the evidence presented here. I note that you now describe a smooth process of evolution of the different granitic types, without mention of the possibility of different magma batches forming the two hypersolvus granites. Strange Lake is interesting because of the interplay of the magmatic and hydrothermal processes, and you have clearly demonstrated the magmatic background, but your final sentence is the key one. I think this paper could discuss the understanding of those hydrothermal processes just slightly more, as context for the importance of the magmatic story.

A statement to the effect that the intrusion of the hypersolvus granite occurred as two separate magma batches (south and north) has been added to the text. The focus of the paper is the magmatic evolution of Strange Lake. We therefore consider that the existing discussion of hydrothermal processes is sufficient.

Figure 1: Note spelling of quartz in key

Corrected. 


\section{The amphiboles of the REE-rich A-type peralkaline Strange Lake pluton - Fingerprints of magma evolution}

Lithos

Karin Siegel, Anthony E. Williams-Jones, Vincent J. van Hinsberg

1

2

\section{ABSTRACT}

Major and trace element compositions of amphibole in igneous environments commonly reflect evolving magma compositions. In this study, we use the amphibole-group minerals from the Strange Lake, REE-enriched peralkaline granitic pluton to gain insights into the evolution of the magma. This 1240 Ma old pluton consists of two main intrusive facies, an early hypersolvus granite, which occurs as separate northern and southern intrusions, and a more evolved transsolvus granite. In the hypersolvus granite the amphibole is a late interstitial phase, whereas in the transsolvus granite, it is present as phenocrysts. The amphibole compositions vary from calcic-sodic (ferro-ferri-katophorite) in the southern hypersolvus granite to sodic (arfvedsonite, ferro-ferri-leakeite) in the other, more evolved granitic units. High $\mathrm{Na}, \mathrm{Si}, \mathrm{Li}$, and low $\mathrm{Al}$ and $\mathrm{Ca}$ concentrations in the amphibole phenocrysts of the transsolvus granite indicate formation from a more evolved magma compared to the hypersolvus granite, despite the fact that these crystals formed early. We interpret the increasing $\mathrm{Fe}^{3+} / \mathrm{Fe}^{2+}$ ratios in the amphibole of the hypersolvus granite to reflect crystal chemical effects (Na/Ca-ratio) and increasingly oxidizing conditions in the magma, whereas in the phenocrysts of the transsolvus granite, the increasing ratio was the product of increasing proportions of $\mathrm{F}^{-}$and $\mathrm{OH}^{-}$in the melt. The amphiboles of all the granite units have elevated $\mathrm{Nb}, \mathrm{Zr}$, Hf and REE concentrations compared to the bulk rock, suggesting that these elements are compatible in amphibole. By contrast the much lower Ti concentration was due to saturation of the magma in sodium-titanosilicates. The amphibole REE concentrations vary greatly among the granite units. Amphibole of the southern and northern hypersolvus granite contains 0.16 and 0.07 wt. \% $\sum \mathrm{REE}+\mathrm{Y}$, on average, respectively, 


\section{The amphiboles of the REE-rich A-type peralkaline Strange Lake pluton - Fingerprints of magma evolution}

Lithos

Karin Siegel, Anthony E. Williams-Jones, Vincent J. van Hinsberg

and in the transsolvus granite, the average $\sum$ REE content is only $0.01 \mathrm{wt}$. \%, despite the more evolved nature of its host transsolvus granite. We intrepret this compositional difference to be due to the fact that the latter represents phenocrysts, which crystallised early, whereas the hypersolvus arfvedsonite is a late interstitial phase. Chondrite-normalized REE profiles emphasise the wide range in LREE-, and the narrow range in HREE-concentrations of the amphiboles. The variations in the LREE-profiles reflect the variable crystallization of primary LREE-bearing phases, including monazite-(Ce), pyrochlore group minerals and gagarinite-(Ce), prior to or contemporaneous with the amphibole, as well as the exsolution of a LREE-rich fluoride melt. The LREE are incompatible in the amphibole structure (apparent $D<0.01$ ) and are preferably accommodated by the octahedral C-site, whereas the HREE occupy the B-site. The chondrite-normalized HREE profiles are steep and display an increasing relative enrichment that culminates in compatible behavior for $\mathrm{Yb}$ and $\mathrm{Lu}$ (apparent $D>1$ ). Owing to their small ionic radius and their compatibility with the amphibole structure, HREE concentrations were more controlled by partitioning (crystal chemical effects) than by the concentrations in the corresponding magma. Large proportions of the bulk HREE content (up to $70 \%$ ) reside in the amphibole, and their later release through hydrothermal replacement helps to explain the extreme and unusual HREE enrichment of the Strange Lake pluton.

\section{KEYWORDS}

Amphibole, REE, Strange Lake, Peralkaline granite, Magma evolution 
The amphiboles of the REE-rich A-type peralkaline Strange Lake pluton Fingerprints of magma evolution

Lithos

Karin Siegel, Anthony E. Williams-Jones, Vincent J. van Hinsberg

\section{Highlights}

- Amphibole compositions reflect magmatic evolution of Strange Lake pluton

- Compositions run from calcic-sodic over sodic to sodic-lithic members with evolution

- $\mathrm{Fe}^{3+}$ concentration result of $\mathrm{Na} / \mathrm{Ca}$ ratio, $f \mathrm{O}_{2}$ and $\mathrm{OH}^{-}$and $\mathrm{F}^{-}$melt concentrations

- Incompatible LREE coupled to Ca concentration (B-site); HREE compatible with C-site

- Significant proportion of Strange Lake bulk HREE content carried by amphibole 


\title{
THE AMPHIBOLES OF THE REE-RICH A-TYPE PERALKALINE STRANGE LAKE PLUTON - FINGERPRINTS OF MAGMA EVOLUTION
}

\author{
Lithos \\ Karin Siegel $^{1)}$, Anthony E. Williams-Jones ${ }^{1)}$, Vincent J. van Hinsberg ${ }^{1)}$ \\ Affiliation / address: \\ ${ }^{1)}$ Department of Earth and Planetary Sciences, McGill University, 3450 University St., FDA, \\ room 238, Montréal, QC H3A 0E8, Canada
}

Corresponding author:

K. Siegel, email: karin.siegel@mail.mcgill.ca, phone: +1 4389929644

Co-authors:

A.E. Williams-Jones, email: ae.williams-jones@mcgill.ca

V. van Hinsberg, email: vincent.vanhinsberg@mcgill.ca 


\section{INTRODUCTION}

2 Our understanding of the genesis of intra-plate rift-generated intrusions that produce A-type

3 granites is still incomplete. In particular, the reasons for the extremely high REE-, F- and other HFSE-concentrations in many of these peralkaline rocks are poorly known. In addition to the need for a highly fertile magma source, magmatic evolution by fractional crystallization appears to play a critical role in the enrichment of these elements (e.g., Kovalenko et al., 1995; Mungall and Martin, 1996). The chemistry of a major mineral, such as amphibole, which adapts to its $P$ $T-X$ environment, and is capable of hosting most cation sizes and charges, can potentially record this and any other processes that might have operated in the magma chamber. As a phenocryst, the amphibole would record the conditions prior to intrusion, and as a late crystallizing phase, the in-situ crystal fractionation processes.

The well-known ability of minerals of the amphibole super-group to accommodate a wide variety of elements with highly variable ionic radius and charge, including alkali elements, high field strength elements (HFSE) and the rare earth elements (REE), makes it an ideal monitor of magma evolution (Abdel-Rahman, 1994; Marks et al., 2004). In this study, we use the occurrence and composition of amphibole-group minerals in the Strange Lake pluton, QuébecLabrador, Canada, to trace the evolution of a peralkaline granitic magma that is unusually enriched in the $\mathrm{REE}, \mathrm{Zr}$ and $\mathrm{Nb}$. This magma was the source of a large REE/HFSE resource (indicated resources: 278 million tons grading 0.93 wt. $\% \mathrm{REE}_{2} \mathrm{O}_{3}, 0.18$ wt. $\% \mathrm{Nb}_{2} \mathrm{O}_{5}$ and 1.92 wt. \% $\mathrm{ZrO}_{2}$; Quest Rare Minerals Ltd., 2012) that is currently being considered for exploitation. In this study, the $\mathrm{Na}, \mathrm{Ca}, \mathrm{Li}, \mathrm{Fe}^{3+}$ and $\mathrm{REE}$ contents of the amphibole-group minerals are used to gain information on the composition of the magma and conditions prior to, during and after its emplacement. The results show that fractional crystallization of a perthitic alkali feldspar, gravity 
settling of REE-minerals and zircon as well as the exsolution of a LREE-rich fluoride melt played a major role in the evolution of the magma and in concentrating the ore elements. They also show that the amphibole-group minerals host a significant proportion of the REE, and were the principal carriers of the HREE in some parts of the pluton.

\section{BACKGROUND INFORMATION}

A number of studies have traced evolutionary trends in alkaline rock suites using the crystal chemistry of the dominant mafic minerals (Davidson, 1982; Marks et al., 2004). In peralkaline rocks, which are defined by a molar excess of alkalis in respect to aluminum, the mafic minerals are usually of a sodic nature, e.g., amphiboles, such as arfvedsonite and riebeckite, or pyroxenes such as aegirine. The amphiboles of alkaline complexes generally trend from calcic through sodic-calcic to sodic members with differentiation, reflecting the increasing alkalinity of the melt from which they crystallized (Giret et al., 1980; Piilonen et al., 2013). They also display significant variations in REE and HFSE concentrations with magmatic differentiation, as shown, for example, by Marks et al. (2004) for the Gardar alkaline province (SW-Greenland). Similar conclusions have been reached for amphibole phenocrysts in alkaline basalts from the Rhine graben valley, Germany (Mayer et al., 2014).

Lithium has proven to be a particularly important constituent of alkali amphiboles (Camara et al., 2010; Hawthorne et al., 1993). Owing to its incompatible character in common rock-forming minerals, its concentration in amphibole may reflect the degree of melt differentiation. This case has been made for lithium-bearing amphiboles from Hurricane Mountain, New Hampshire, where the amphiboles vary from early Li-rich leakeite to late $\mathrm{Li}$-poor riebeckite (Hawthorne et al., 1996). The progressive depletion in lithium in crystals growing into miarolitic cavities in 
granitic pegmatites is consistent with the idea that a highly evolved melt with a high Li content formed the earlier leakeite, and that progressive fluid exsolution resulted in the removal of lithium and the growth of Li-poor riebeckite.

The 1240 Ma Strange Lake pluton (Miller et al., 1997) is an extraordinary example of hyperREE-, $\mathrm{Zr}-$, and $\mathrm{Nb}-$ enrichment in a peralkaline granite, and is composed of a sequence of granitic intrusions, two earlier hypersolvus granites and a later transsolvus granite (this study).

The last of these intrusions is host to numerous NYF-type pegmatites with extremely high concentrations of REE, particularly the heavy REE (HREE), $\mathrm{Zr}$ and $\mathrm{Nb}$. Most of the previous studies of the pluton have focused on the hydrothermal alteration and the rare-metal mineralized pegmatites (Gysi et al., 2016; Gysi and Williams-Jones, 2013; Kerr and Rafuse, 2012; Salvi and Williams-Jones, 1990; 1992; 1996; 1997; 2006; Vasyukova et al., 2016). Several studies, however, have addressed its magmatic evolution. Boily and Williams-Jones (1994) proposed that the REE-enrichment was due to a combination of fractional crystallization, and the heterogeneous distribution of F-rich residual melts, in which the REE and HFSE were transported as fluoro-complexes. Vasyukova and Williams-Jones (2014; 2016) provided evidence for the early separation of a REE- and Y-rich immiscible fluoride melt from the silicate melt, which accumulated in the highly evolved residual melts that formed the mineralized pegmatites.

Previous studies of the mafic minerals of the Strange Lake pluton concluded that the amphiboles are enriched in $\mathrm{Li}$ and $\mathrm{Zn}$, are associated with Ti-silicates and crystallized under relatively low $f \mathrm{O}_{2}$ (Pillet et al., 1993; Roelofsen, 1997). Hawthorne et al. (2001) showed that $\mathrm{Li}$ is an essential component of the amphiboles and identified lithian arfvedsonite and lithian manganoan arfvedsonite. 


\section{GEOLOGIC SETTING}

The Strange Lake pluton is part of the Nain Plutonic AMCG suite, which comprises anorthosites, mangerites, charnockites and granites (Miller, 1996; Gower and Krogh, 2002). Rocks of the Nain suite were emplaced along the boundary between the Archean Nain province and the Archean to Early Paleoproterozoic Churchill province (Emslie et al., 1994), more recently referred to as the Core Zone (James and Dunning, 2000). The Nain Plutonic Suite covers an area of $\sim 19,000 \mathrm{~km}^{2}$, and was emplaced between 1460 and $1240 \mathrm{Ma}$, with the Strange Lake pluton (1240 $\pm 2 \mathrm{Ma})$ representing the youngest intrusive body (Gower and Krogh, 2002).

To the south and west, the Strange Lake pluton intrudes the Napeu Kainiut quartz monzonite, which is interpreted to represent a satellite body of the Mistastin batholith (Miller et al., 1997). The Napeu Kainiut intrusion, which is composed mainly of quartz, K-feldspar, plagioclase and biotite, also occurs within the Strange Lake pluton as xenoliths and large roof pendants. The Mistastin batholith consists of pyroxene- and fayalite-bearing Rapakivi-textured granites, which were cut by younger biotite-hornblende-bearing granites and minor syenitic intrusions, such as the Misery Lake syenite, which hosts abundant REE mineralization (Petrella et al., 2014). Dated at 1420 Ma (Emslie and Stirling, 1993), the Mistastin batholith represents one of the oldest members of the Nain Plutonic Suite. The other host rock to the Strange Lake pluton is an Archean to Paleoproterozoic gneiss complex belonging to the Core Zone (Churchill Province), comprising quartzofeldspathic augen-gneiss, banded biotite gneiss and minor garnet-bearing paragneiss and mafic gneiss.

\subsection{The Strange Lake Pluton}


The circular (in outcrop), $\sim 6 \mathrm{~km}$ in diameter, Strange Lake pluton is located on the border between Québec and Labrador, and consists of a sequence of alkaline granitic intrusive units (Fig. 1). The earliest phase of the pluton is a hypersolvus granite (Pillet et al., 1992), its formation at conditions above those for the alkali feldspar solvus (Tuttle and Bowen, 1958). The hypersolvus granite occurs in the center and southern part of the pluton, and has been subdivided into a northern and a southern unit, based on bulk rock and mineral compositional differences. The third major unit, formerly classified as subsolvus granite (Boily and Williams-Jones, 1994; Salvi and Williams-Jones, 1996; Gysi and Williams-Jones, 2013), is now classified as transsolvus granite, and contains perthite phenocrysts as well as separate albite and K-feldspar crystals in the groundmass. It occupies much of the pluton, and has been strongly affected by hydrothermal activity. A smaller, unaltered part of the transsolvus granite is exposed in the center of the pluton and provided the samples for this study. The transsolvus granite commonly contains dark grey, fine-grained ovoid enclaves and barren pegmatite pockets; the altered transsolvus granite is host to highly REE/HFSE-enriched pegmatites. A dark grey porphyritic microgranite with a fine-grained matrix occurs in contact with remnants of country rock within the pluton and is interpreted to represent quenched hypersolvus granite. The enclaves in the transsolvus granite, some of which are compositionally similar to the hypersolvus granite, are interpreted to represent fragments of this quenched material; the other fragments represent quenched transsolvus granite. The pluton is surrounded by a purple to dark red fluorite-hematite breccia, delineating a ring-fault that contains angular fragments of the host rocks.

\subsection{Hypersolvus granite}

The hypersolvus granite has been subdivided into an equigranular and fine-grained northern part and a variably textured fine- to coarse-grained southern part (this study). Locally, the southern 
113 hypersolvus granite is coarse-grained and displays poikilitic to pegmatitic textures, which are

114 also observed in drill core of the northern hypersolvus granite (not sampled). These poikilitic

115 textured samples contain anhedral arfvedsonite oikocrysts enclosing smaller crystals of perthitic

116 alkali feldspar, whereas the pegmatitic samples are coarse-grained and contain comb-textured

117 arfvedsonite, quartz, K-feldspar and minor proportions of alkali zirconosilicate minerals. Both

118 the northern and southern hypersolvus granite units are composed of perthitic feldspar, quartz,

119 and sodic amphibole. Minor microcline and albite are present in the groundmass, either

120 reflecting evolution of the magma to conditions in the two-feldspar stability field or subsolidus

121 hydrothermal crystallization. A number of alkali feldspar crystals of the southern hypersolvus

122 granite contain inclusions of fibrous astrophyllite. The quartz and sodic amphibole both occur

123 interstitially to the perthite, and the amphibole appears to have crystallized later than the quartz

124 (Fig. 2a). In most of the southern hypersolvus granite samples, the amphibole exhibits swapped

125 margins with perthite (Fig. 2b). The amphibole contains numerous inclusions of fluorite and a Y-

126 rich fluorite-fluocerite solid solution, particularly in the cores of crystals (Fig. 3a). In addition to

127 the silicates mentioned above, a variety of interstitial zirconosilicate minerals, e.g., vlasovite,

128 elpidite, dalyite and catapleiite replaced primary zircon (remnants of zircon in crystal cores).

129 Titanosilicates occur mostly in the northern hypersolvus granite, and locally replaced the sodic

130 amphibole. These minerals comprise dark red aenigmatite $\left(\mathrm{Na}_{2} \mathrm{Fe}^{2+}{ }_{5} \mathrm{TiSi}_{6} \mathrm{O}_{20}\right)$ and yellow fibrous

131 astrophyllite $\left((\mathrm{K}, \mathrm{Na})_{3}\left(\mathrm{Fe}^{2+}\right)_{7} \mathrm{Ti}_{2} \mathrm{Si}_{8} \mathrm{O}_{26}(\mathrm{OH})_{4}\right)$ (Figs. 2c, 3b). The primary REE-minerals of both

132 the northern and southern hypersolvus granite are monazite-(Ce) and fluornatropyrochlore. The

133 monazite-(Ce) crystals are small and euhedral, and occur as inclusions in the perthitic alkali

134 feldspar. Fluor-natropyrochlore is more abundant, and occurs as pyramidal crystals in the

135 groundmass, or as inclusions in the alkali feldspar. The oikocrystic and pegmatitic textured 
samples contain a much smaller proportion of primary REE minerals than the fine-grained varieties of the same unit. Fluorite is an abundant accessory mineral and forms small to large, rounded, translucent to purple inclusions in sodic amphibole or is disseminated interstitially through the rock. It is usually rimmed by the Y-rich fluorite-fluocerite solid solution, which is brighter in BSE images (Fig. 3a). Locally, gagarinite-(Y) occurs in association with fluorite and the fluorite-fluocerite solid solution, and is interpreted to be secondary.

\subsection{Transsolvus granite and enclaves}

The transsolvus granite unit, which contains abundant fine-grained, dark grey ellipsoidal enclaves, surrounds and partially intruded the hypersolvus granite. The unaltered part of this intrusion at the center of the pluton is composed of the same major minerals as the hypersolvus granite, i.e., perthitic alkali feldspar, arfvedsonite and quartz. However, in contrast to the hypersolvus granite, microcline and albite form an essential part of the groundmass, indicating that the transsolvus granite crystallized at a lower temperature and/or higher $\mathrm{pH}_{2} \mathrm{O}$ than the hypersolvus granite (Tuttle and Bowen, 1958). Amphibole in this granitic facies forms prismatic phenocrysts that locally contain inclusions of microcline and albite (Fig. 3c), but in contrast to amphibole in the hypersolvus granite, they rarely contain fluorite inclusions. Locally, the amphibole has been replaced by aegirine (Fig. 2d) and, in the more heavily altered parts of the pluton, hematite. Quartz forms round crystals that display a snowball texture, in which primary albite nucleated on the faces of the crystal. Alkali zirconosilicates, such as vlasovite and elpidite, occur intersitially, and usually occupy a larger proportion of the rock volume than in the hypersolvus granite. Narsarsukite $\left(\mathrm{Na}_{2}\left(\mathrm{Ti}_{1} \mathrm{Fe}^{3+}\right) \mathrm{Si}_{4}(\mathrm{O}, \mathrm{F})_{11}\right)$, the sole sodium-titanosilicate, occurs as large tabular beige poikilitic crystals, and is observed in the dark grey enclaves and in a number of transsolvus granite samples. Titanite has been reported to occur in the altered parts 
159 (Birkett et al., 1996), and is an abundant phase in the pegmatites of the transsolvus granite (Gysi 160 et al., 2016). The primary REE minerals are fluornatropyrochlore, monazite-(Ce) and gagarinite-

161 (Ce), which was replaced by bastnäsite-(Ce). Fluorbritholite-(Ce) occurs sparsely and 162 interstitially in association with fluorite. Fluorite occurs as a late magmatic, interstitial 163 (translucent) or hydrothermal (purple) phase, and is less abundant than in the hypersolvus 164 granite. The transsolvus granite hosts a large number of NYF-type pegmatites with border zones 165 of K-feldspar, quartz, sodic amphibole and alkali zirconosilicates, and a strongly altered core 166 with quartz, fluorite and exotic REE minerals, as well as zircon and pyrochlore (Gysi and 167 Williams-Jones, 2013). These pegmatites host the bulk of the rare metal mineralization in the 168 deposit and have been the target of recent mineral exploration.

A dark grey, porphyritic microgranite exposed within the Strange Lake pluton contains perthitic alkali feldspar phenocrysts, quartz eyes and fine-grained subhedral to phenocrystic arfvedsonite in the groundmass (Fig. 3d). Locally, this unit was intruded by a leucocratic transsolvus granite, which, texturally and mineralogically, is similar to the dark grey enclaves observed in the transsolvus granite. This unit has a bulk composition slightly less evolved than, and a mineralogy similar to that of the transsolvus granite. The fine-grained, dark grey enclaves hosted by the transsolvus granite are ellipsoidal in shape, range from a few $\mathrm{cm}$ up to $50 \mathrm{~cm}$ in diameter and have sharp edge contacts in most cases. These enclaves are composed of perthitic alkali feldspar phenocrysts embedded in a matrix of fine-grained quartz, microcline, albite and finely distributed subhedral and locally phenocrystic sodic amphibole, which gives them their dark appearance.

\section{METHODS}

\subsection{Material}


181 The major and trace element compositions of the amphibole-group minerals were determined in

18222 least-altered rock samples. All granite types occurring in the unaltered portion of the Strange

183 Lake pluton were considered (Fig. 1). Bulk-rock compositions of the samples were provided by

184 Quest Rare Minerals Ltd., and represent the results of analyses by Actlabs using XRF (X-ray

185 fluorescence) for $\mathrm{Nb}$, ISE-MS (ion selective electrode) for $\mathrm{F}$, fusion-ICP-OES for major

186 elements and fusion ICP-MS for most trace elements.

187

188

189

190

191

192

193

194

195

196

197

198

199

200

201

202

\subsection{Electron-microprobe analyses}

The composition of the amphibole-group minerals in $30 \mu \mathrm{m}$ thick, carbon-coated polished thin sections was determined using a JEOL JXA-8900L electron microprobe (EMP) at the Department of Earth and Planetary Sciences, McGill University. The beam current was $20 \mathrm{nA}$, the acceleration voltage $20 \mathrm{kV}$, and the beam diameter $10 \mu \mathrm{m}$. Counting times and standards used for analyses as well as detection limits based on repeated standard analyses are listed in the appendix. To ensure analysis of the same spots by both EMP and LA-ICP-MS (see below), backscattered electron micrographs (BSE) of the analyzed grains were taken.

\subsection{Laser-ablation analyses}

Laser ablation ICP-MS (LA-ICP-MS) analyses were conducted on 16 samples using a NewWave 213 nm Nd-YAG laser-ablation system and a Thermo Finnigan iCapQc quadrupole ICP-MS at the Department of Earth and Planetary Sciences, McGill University. Six samples were analysed at Université du Québec à Montreal (UQAM) using a Photon Machine G2 shortpulse (4ns) laser-ablation system (193 nm excimer) and a $\mathrm{Nu}$ AttoM high-resolution magnetic sector ICP-MS. The amphibole-group minerals were analyzed for selected major and trace elements in the same $30 \mu \mathrm{m}$-thick polished sections. NIST SRM 610 glass was used as the 
primary standard, and EMP data for both $\mathrm{Si}$ and $\mathrm{Ti}$ were used as internal references. The analyses were performed with a $5 \mathrm{~Hz}$ repetition rate, on material ablated from a $20 \mu \mathrm{m}$ diameter pit. Data reduction was carried out using the software, Iolite, version 2.5. The estimated precision is $5-10 \%$ for each element.

\subsection{Amphibole formulae}

The amphibole-group mineral formulae were calculated on the basis of $\mathrm{O}+\mathrm{OH}+\mathrm{F}=24$ atoms per formula unit (apfu) and $\mathrm{OH}=2-2 \mathrm{Ti}$, using the amount of $\mathrm{Ti}^{4+}$ as a proxy for the (maximum) oxy-component in the mineral structure (Hawthorne et al., 2012). The formula calculation was performed following the latest IMA 2012 recommendations (Hawthorne et al., 2012; Oberti et al., 2012) using the Excel spreadsheet of Locock (2014). On the basis of a preliminary formula calculation after Leake et al. (1997), the following cation normalization schemes were chosen: $\mathrm{Si}-\mathrm{Ca}+\mathrm{Li} \leq 15, \mathrm{Si}-\mathrm{Na} \geq 15$ and $\mathrm{Si}-\mathrm{K} \leq 16$. As some fluorite inclusions in the amphibole from the hypersolvus granite were too small to be detected by imaging, analyses returning high concentrations of both $\mathrm{Ca}(>3$ wt. \%) and F (> 2 wt. \%) were removed from the dataset.

\section{RESULTS}

\subsection{Bulk rock compositions}

The average (median) major and trace element bulk-rock compositions of the unaltered Strange Lake granites are reported in Table 1 . The agpaitic indices (molar $[\mathrm{Na}+\mathrm{K}) / \mathrm{Al}])$ of all units are $>1$ and hence classify the rocks as peralkaline. The granites generally have low $\mathrm{Ca}$ and $\mathrm{Mg}$ and high alkali, Fe, F, Zn, Rb, Zr, Nb and REE concentrations. The evolution of the granites is reflected by decreasing $\mathrm{Al}$, and increasing $\mathrm{Si}, \mathrm{Fe}$ and incompatible element concentrations (i.e., REE, $\mathrm{Nb}$, $\mathrm{Zr}$ ). The agpaitic index also increases with evolution. The fine-grained southern hypersolvus 
granite, based on the above mentioned element concentrations, is interpreted to represent the least evolved rock unit. The oikocrystic / pegmatitic textured members of this unit has higher Si and Fe concentrations, a higher agpaitic index and slightly elevated REE and Zr concentrations. The concentrations of the HFSE (REE, Th, U, Nb, Zr, Hf) in the northern hypersolvus granite are higher, whereas Al concentrations are lower than those in the southern hypersolvus granite, suggesting that it is more evolved. The transsolvus granite generally has high $\mathrm{Si}, \mathrm{REE}, \mathrm{Zr}, \mathrm{Nb}$, $\mathrm{Rb}$ and $\mathrm{F}$ concentrations and significantly lower $\mathrm{Al}$ and $\mathrm{Ca}$ concentrations than the hypersolvus granite, and is considered to be the most evolved member of the suite. The dark grey enclaves hosted in the transsolvus granite have high $\mathrm{Al}, \mathrm{K}$ and $\mathrm{Ca}$, and low $\mathrm{Na}, \mathrm{Fe}, \mathrm{Ti}, \mathrm{Zr}$ and $\mathrm{Nb}$ concentrations compared to the other granite types. Their REE concentrations are lower than those of their host, but higher than those of the hypersolvus granites.

\subsection{Formula assignments}

The amphibole-group minerals have the general structural formula, $\mathrm{AB}_{2} \mathrm{C}_{5} \mathrm{~T}_{8} \mathrm{O}_{22} \mathrm{~W}_{2}$. The A-site of the Strange Lake amphiboles is occupied by $\mathrm{Na}^{+}$and minor $\mathrm{K}^{+}$, and the $\mathrm{B}$-site by $\mathrm{Na}^{+}$and $\mathrm{Ca}^{2+}$, which assigns them to the alkali group. The octahedral $\mathrm{C}$-site is occupied by $\mathrm{Ti}^{4+}, \mathrm{Zr}^{4+}$, $\mathrm{Al}^{3+}, \mathrm{REE}^{3+}, \mathrm{Fe}^{3+}, \mathrm{Zn}^{2+}, \mathrm{Mn}^{2+}, \mathrm{Fe}^{2+}, \mathrm{Mg}^{2+}$ and $\mathrm{Li}^{+}$. The tetrahedral T-site is occupied by $\mathrm{Si}^{4+}$, ${ }^{\mathrm{T}} \mathrm{Al}^{3+}$ and in some cases ${ }^{\mathrm{T}} \mathrm{Ti}^{4+}$. The $\mathrm{W}$-site is dominated by the anions $\mathrm{F}^{-}, \mathrm{Cl}^{-}$and $\mathrm{OH}^{-}$, which assigns the amphiboles to the hydroxy-fluoro-chloro-group, where ${ }^{\mathrm{W}} \mathrm{F}>{ }^{\mathrm{W}} \mathrm{OH},{ }^{\mathrm{w}} \mathrm{Cl}$, and a "fluoro"-prefix is assigned to the amphibole name, which was the case for the majority of the crystals analyzed (see Table 2). In the matter of nomenclature, we have followed the latest IMA recommendations (Hawthorne et al., 2012; Oberti et al., 2012). 
The C-site has a consistent under-occupancy ( $<5 \mathrm{apfu}$ ), whereas the A-site has an overoccupancy (> 1 apfu) (see Table 2). Despite using a variety of calculation procedures (Hawthorne et al., 2012; Leake et al., 1997; Oberti et al., 2012), normalization schemes, and varying the $\mathrm{Fe}^{2+} / \mathrm{Fe}^{3+}$ ratios and oxo-components, we were unable to reduce the under-occupancy and over-occupancy of the C- and A-sites, respectively. This issue has been reported to be common for alkali amphiboles in peralkaline rocks, such as arfvedsonite or riebeckite, by other researchers, who have deemed it to be an irresolvable artefact (Czamanske and Dillet, 1988; Hawthorne, 1976; Hawthorne et al., 1993). Hawthorne (1976) suggested that some of the B-site cations, notably $\mathrm{Ca}^{2+}$, theoretically could be accommodated in the $\mathrm{C}$-site on the basis of bondlength constraints. This would result in a total C-site occupation closer to $5 \mathrm{apfu}$, and shift the excess A-site cations to the B-site.

The occupancy of the A- and B-sites determines whether the amphiboles analyzed belong to the sodic subgroup (arfvedsonite, leakeite) or the sodic-calcic subgroup (katophorite), in which ${ }^{\mathrm{B}} \mathrm{Ca}$ $>$ 0.5. Ferro-ferri-katophorite was identified in the least evolved fine- to medium-grained samples of the southern hypersolvus granite, exclusively. All the other amphiboles belong to the sodic subgroup, and in the cases of a calculated $\mathrm{Fe}^{2+} / \mathrm{Fe}^{3+}$ ratio of 1.1 to 2.3 , have been classified as arfvedsonite. The solid solution between the endmembers, arfvedsonite and katophorite, is displayed in Figure 4a. In principle, the location of endmember arfvedsonite could lie anywhere on the Na-K axis, as a potassic endmember has not been shown to exist in nature. The occupancy of the C-site divides the sodic amphibole subgroup into arfvedsonite and ferro-ferri-leakeite; the latter has ${ }^{\mathrm{C}} \mathrm{Li}>0.5$ apfu and a $\mathrm{Fe}^{2+} / \mathrm{Fe}^{3+}$ ratio between 0.7 and 1.3. Ferro-ferri-leakeite is the principal amphibole in the transsolvus granite but also occurs in the northern hypersolvus granite. The fluoride-rich-variety (ferro-ferri-fluor-leakeite) was detected mainly in the 
transsolvus granite and its enclaves, whereas the fluoride-poor variety occurs predominantly in the northern hypersolvus granite. The composition of the analyzed solid-solution between the endmembers, arfvedsonite and ferro-ferri-leakeite, is displayed in Figure $4 \mathrm{~b}$. The slope of the trend from the arfvedsonite to leakeite endmembers indicates an increase in $\mathrm{Fe}^{3+}$ with increasing $\mathrm{Li}^{+}$. The end-member stoichiometric formulae of the amphibole-group minerals present in the unaltered granites of the Strange Lake pluton are listed in Table 3.

\subsection{Major elements}

The major element compositions of the analyzed amphibole are reported in Table 4 (mean values) and illustrated in Figure 5 relative to their Al content. Aluminum was chosen because the Al content of amphibole is commonly a reliable indicator of the differentiation of the corresponding magma, if alkali feldspar fractionation (perthite phenocrysts) was the major control on magma evolution (Hawthorne et al., 2001; Piilonen et al., 2013). As shown in Figure 5a, the Ca content decreases with decreasing $\mathrm{Al}$ content in a ratio slightly greater than $1: 1$, and is highest and shows the greatest range ( 0.3 to $0.6 \mathrm{apfu})$ in the amphibole of the fine-grained granite from the southern hypersolvus granite. The $\mathrm{Ca}$ content is lower in the pegmatitic and oikocrystic textured samples of the same unit (0.1 to $0.35 \mathrm{apfu})$. Amphibole of the northern hypersolvus granite has a much lower Ca concentration, between 0.05 and 0.2 apfu. The lowest Ca concentrations are for amphibole in the enclaves and the transsolvus granite $(\leq 0.1 \mathrm{apfu})$ (Fig. 5a). Sodium exhibits the opposite trend to $\mathrm{Ca}$, with concentrations increasing with decreasing $\mathrm{Al}$ content. In the fine- to medium-grained samples of the southern hypersolvus granite, Na-contents are relatively low, between 2.1 and 2.6 apfu, whereas in the oikocrystic to pegmatitic samples, the Na contents are consistently higher, between 2.6 and 2.9 apfu, and are similar to those of the amphibole from the northern hypersolvus granite, the enclaves and the transsolvus granite (Fig. 
5b). The Ti content of amphibole in the fine- to medium-grained samples of the southern hypersolvus granite has a similar range to that in the northern hypersolvus granite, i.e., from 0.08 to 0.22 apfu versus 0.1 to 0.21 apfu, but because of the much lower Al content of the amphibole in the northern hypersolvus granite samples, the two datasets display separate Ti-Al trends (Fig. 5c). Amphiboles in the oikocrystic to pegmatitic samples of the southern hypersolvus granite, the transsolvus granite and the enclaves all have relatively low Ti contents (0.06 to 0.16 apfu) (Fig. 5c). Silica in amphibole behaves similarly to $\mathrm{Na}$, increasing in concentration with decreasing $\mathrm{Al}$ concentration. The lowest silica concentrations are those of the fine- to medium-grained samples 300 of the southern hypersolvus granite (7.4 to $7.7 \mathrm{apfu}$ ) (Fig. 5d); the oikocrystic to pegmatitic samples display the largest range in amphibole Si content, from 7.4 to 8.0 apfu. Amphibole in the northern hypersolvus granite, the enclaves and the transsolvus granite has $\mathrm{Si}$ contents from 7.7 to 7.9, 7.6 to 7.9 and 7.6 to 8 apfu, respectively (Fig. 5d). Manganese contents of amphibole are highest in the northern hypersolvus granite $(0.09-0.12)$ and show the greatest range in the transsolvus granite $(0.06-0.12)$ (Fig. 5e). They are broadly similar for amphibole from the enclaves and the southern oikocrystic to pegmatitic hypersolvus granite $(0.07-0.10)$, and range from 0.08 to 0.11 for amphibole from the fine-grained southern hypersolvus granite. The calculated $\mathrm{Fe}^{2+} / \mathrm{Fe}^{3+}$ ratios correlate weakly with the Al concentrations. Amphibole from the finegrained southern hypersolvus granite generally has the highest $\mathrm{Fe}^{2+} / \mathrm{Fe}^{3+}$ ratio; amphibole from the enclaves, the northern hypersolvus granite and many of the transsolvus granite samples has a low ratio (Fig. 5f). Zinc concentrations are slightly elevated for the amphibole from the finegrained samples of the southern hypersolvus granite (avg. 0.08 apfu) and the enclaves (avg. 0.07 apfu), compared to the amphibole of the northern hypersolvus granite, the transsolvus granite and the oikocrystic and pegmatitic samples of the southern hypersolvus granite (all avg. 0.05 
315 apfu) (Fig. 5g). Fluorine concentration is highest in the amphibole of the transsolvus granite (1.0

$316-1.4 \mathrm{apfu}$ ), lowest for the crystals of the (fine-grained) southern hypersolvus granite $(0.2-0.8$

317 apfu) and is intermediate (avg. 1 apfu) for all the other granite units.

318 The amphibole phenocrysts of the transsolvus granite differ only slightly in composition from

319 core to rim (Fig. 6; Table 5). The phenocryst cores have total Al and Si contents averaging 0.06

320 (apfu) and 7.9 (apfu), respectively, a considerable range in Ca concentration ( $\sim .1$ to 0.5 apfu,

321 avg. 0.03 apfu), $\mathrm{Na}$ and $\mathrm{K}$ contents averaging 2.8 and 0.33 apfu, respectively, a $\mathrm{Fe}^{3+}$ content

322 averaging $1.8 \mathrm{apfu}$, a Mg content averaging $0.03 \mathrm{apfu}$, a total Ti content of 0.09 apfu (avg.), Mn

323 and $\mathrm{Zn}$ contents averaging 0.07 and 0.05 apfu (avg.), respectively, and a F content averaging 1.2

324 apfu. The phenocryst rims have lower concentrations of Al (avg. 0.06 apfu), Si (7.7 apfu), Ca

325 (avg. 0.02 apfu), $\mathrm{Na}$ (avg. $2.8 \mathrm{apfu}$ ), Mg (avg. 0.02) and F (avg. 1.1 apfu), and higher

326 concentrations of total $\mathrm{Fe}^{3+}$ (avg. 2.2 apfu), K (avg. 0.4 apfu), total Ti (0.1 apfu), Mn and Zn

327 (avg. 0.09 and 0.07 apfu, respectively).

328

\subsection{The REE and other trace elements}

The shapes of the chondrite-normalized amphibole REE profiles (Sun and McDonough, 1989) are similar for all the granite units and, in general, are characterized by relatively flat light and middle REE parts, a marked negative Eu-anomaly $\left(\mathrm{Eu} / \mathrm{Eu}^{*}=0.04-0.66\right)$ and an enrichment in the HREE (Fig. 7). However, the absolute REE concentrations differ considerably. The amphiboles of the fine-grained samples of the southern hypersolvus granite have the highest total REE concentration, on average (median value) $0.16 \pm 0.03$ wt. \% (Table 4). By contrast, oikocrystic to pegmatitic samples of the same unit have much lower amphibole REE concentrations, on average, $0.04 \pm 0.01 \mathrm{wt} . \%$. The total REE concentrations of amphibole in the 
northern hypersolvus granite are intermediate between those of the fine-grained and oikocrystic to pegmatitic southern hypersolvus granite, averaging $0.07 \pm 0.02 \mathrm{wt} \%$. Amphiboles of the transsolvus granite and its enclaves have much lower total REE concentrations, averaging $0.01 \pm$ 0.002 wt. $\%$ and $0.04 \pm 0.01$ wt. $\%$, respectively (Table 4). The amphibole REE concentrations are between $10^{2}$ and $10^{3}$ times the chondrite values (Fig. 7c, e).

The contents of the individual REE in the amphiboles are significantly lower (in the case of the light REE (LREE), more than an order of magnitude lower) than their respective bulk host rock concentrations, except for the heaviest of the REE, $\mathrm{Yb}$ and $\mathrm{Lu}$, which are significantly higher (Fig. 7). In the case of the fine-grained southern hypersolvus granite, the exception extends to the middle REE and for $\mathrm{Yb}$ and $\mathrm{Lu}$ the content in amphibole is about four times higher than the bulk rock content (Fig. 7a). The concentrations of $\mathrm{Yb}$ and $\mathrm{Lu}$ of the amphiboles from the northern hypersolvus granite exceed the bulk rock concentrations to a similar degree (Fig. 7c). The largest difference between amphibole and bulk rock REE concentrations is exhibited by the transsolvus granite, which has considerably higher concentrations in the bulk rock except for $\mathrm{Yb}$ and $\mathrm{Lu}$; the amphibole in this unit also shows the steepest chondrite-normalized rise in HREE concentration (Fig. 7e). The amphiboles in the dark-grey enclaves hosted by this unit have elevated light to middle REE compositions compared to that of amphibole in the transsolvus granite, whereas the As is the case for the REE, the contents of most of the other trace elements are considerably lower in the amphibole-group minerals than in the average bulk-rock (other than in the southern 357 fine- to medium-grained hypersolvus granite). Conspicuous exceptions are $\mathrm{Nb}, \mathrm{Zr}$ and $\mathrm{Hf}$, which 358 in addition to being present in zircon, monazite-(Ce) and the pyrochlore group minerals, are also accommodated by the amphibole. The chondrite-normalized trace element profiles for the 
amphiboles in all granite units have negative $\mathrm{Ba}, \mathrm{U}, \mathrm{K}, \mathrm{Pb}, \mathrm{Sr}, \mathrm{Eu}$, Ti and $\mathrm{Y}$ anomalies, and positive $\mathrm{Th}, \mathrm{Nb}$, Ta, Sn, REE, $\mathrm{Zr}$ and $\mathrm{Hf}$ anomalies, whereas the average bulk rock has negative $\mathrm{Ba}, \mathrm{K}, \mathrm{Pb}, \mathrm{Sr}, \mathrm{Eu}$, and $\mathrm{Ti}$ and positive Th, U, Nb, Ta, REE, Zr, Hf and Y anomalies (Fig. 7). Thus, although the behavior of most elements in the amphibole is similar to that in the host rock, U and Y show opposite behavior, i.e., their concentrations are anomalously low in the amphibole and high in the bulk rock. Zirconium concentrations are lowest in amphibole from the southern hypersolvus granite (avg. 0.07 to $0.12 \mathrm{wt} . \%$ ), and reach more than double these concentrations in amphibole from the northern hypersolvus granite $(\sim 0.26$ wt. \%). Concentrations are intermediate between these extremes in the amphibole of the transsolvus granite $(\sim 0.14$ wt. $\%)$ and enclaves ( 0.21 wt. \%). Lithium concentrations, on average, are lowest in amphibole of the southern hypersolvus granite (avg. 0.15 to $0.16 \mathrm{wt}$ \%), significantly higher in amphibole of the northern hypersolvus granite (avg. 0.31 wt. \%) and by far the highest in amphibole of the transsolvus granite (avg. 0.58 wt. \%) and enclaves (avg. 0.48 wt. \%). However, they vary greatly among samples, and, to a lesser extent, among crystals in the same sample (see Table 4).

Differences in the chondrite-normalized REE profile are particularly marked among the five amphibole types identified in this study. Sodium- and calcium-rich ferro-ferri-katophorite as well as arfvedsonite have the highest total REE concentrations; their average $\mathrm{La}_{\mathrm{N}} / \mathrm{Yb}_{\mathrm{N}}$ ratios are 0.23 and 0.49, respectively (Fig. 8). Fluoro-arfvedsonite and Li-rich ferro-ferri-leakeite both have intermediate REE concentrations and a more prominent HREE enrichment with an average $\mathrm{La}_{\mathrm{N}} / \mathrm{Yb}_{\mathrm{N}}$ ratio of 0.09 and 0.14 , respectively. Ferro-ferri-fluoro leakeite has by far the lowest total REE concentration, and it exhibits the strongest relative HREE enrichment with an average $\mathrm{La}_{N} / \mathrm{Yb}_{\mathrm{N}}$ ratio of. 0.04

\section{DISCUSSION}




\subsection{Amphibole composition as a tracer of granite differentiation}

384 The variations in the major and trace element chemistry of amphibole in the Strange Lake pluton 385 are interpreted to reflect the evolution of the granitic melt. The earliest intrusive phase was the hypersolvus granite, which has been subdivided into a southern and a northern part on the basis of compositional and mineralogical differences. In both units, the amphiboles, mainly (fluoro)arfvedsonite $(n=49)$ and minor (fluoro)-katophorite $(n=6)$, occur interstitially to perthite and quartz, and thus were the last of the main rock-forming minerals to crystallize. By contrast, in the more evolved transsolvus granite, the amphibole, mostly fluoro-arfvedsonite and ferro-ferri(fluoro)-leakeite $(n=55)$, occurs as phenocrysts together with minor perthite, and therefore crystallized prior to the emplacement of this granite facies. This difference in the timing of crystallization of the amphibole, as we will show below, played a crucial role in determining the extent to which incompatible elements, such as the REE and other HFSE, were incorporated in its crystal structure.

\subsection{Magma evolution monitored by A-and B-site occupancy}

In the hypersolvus granite, the A- and B-sites are occupied mainly by $\mathrm{Na}$, but also by considerable $\mathrm{Ca}$ in some samples of the southern hypersolvus granite (see Fig. 4a). The high density of fluorite inclusions also suggests that the early melt was relatively rich in $\mathrm{Ca}$. The occupation of the $\mathrm{B}$-site by the bivalent $\mathrm{Ca}$ ion was balanced by $\mathrm{Al}^{3+}$ at the $\mathrm{T}$-site. With increasing degree of differentiation, $\mathrm{Na}^{+}$substituted for $\mathrm{Ca}^{2+}$ and $\mathrm{Si}^{4+}$ for $\mathrm{Al}^{3+}$ (see Figs. 5a, b, d). This coupled substitution can be expressed by the reaction:

$$
{ }^{\mathrm{B}} \mathrm{Ca}^{2+}+{ }^{\mathrm{T}} \mathrm{Al}^{3+} \rightarrow{ }^{\mathrm{B}} \mathrm{Na}^{+}+{ }^{\mathrm{T}} \mathrm{Si}^{4+}
$$


404 A similar correlation of decreasing $\mathrm{Ca}$ and increasing $\mathrm{Si}$ in amphibole with magmatic evolution

405 has been documented for silica-undersaturated alkaline intrusive suites, namely Ilímaussaq in

406 southern Greenland (Marks et al., 2004), the Khibiny complex in the Kola Peninsula of Russia

407 (Konopleva et al., 2008), and the alkaline pegmatites of the silica-undersaturated to -saturated

408 Larvik plutonic suite of the Oslo Rift in Southern Norway (Piilonen et al., 2013). In these three

409 locations, the amphibole composition evolved from calcic to sodic-calcic to sodic varieties with

410 increasing degree of differentiation, reflecting the increasing alkalinity of the corresponding

411 magma.

412 As the Ca content is highest in amphibole of the fine- to medium-grained southern hypersolvus

413 granite (see Fig. 5a), we interpret this unit to be the earliest and least evolved intrusive facies of

414 the Strange Lake pluton. The much lower content of $\mathrm{Ca}$ in amphibole of the oikocrystic to

415 pegmatitic textured granites from the same unit is consistent with the interpretation that these

416 rocks crystallized from residual melts. Consistent with these interpretations, the northern

417 hypersolvus granite, in which amphibole has a relatively low $\mathrm{Ca}$ (and $\mathrm{Al}$ ) concentration,

418 represents the intrusion of a separate and more evolved batch of magma.

419 The amphibole of the transsolvus granite generally has low $\mathrm{Ca}$ - and $\mathrm{Al}-$, as well as high $\mathrm{Na}-$ and

420 Si-concentrations (see Fig. 5a, b, d), which all point towards a significantly more evolved melt.

421 As the amphibole of this unit crystallized early (it occurs as phenocrysts), as opposed to the

422 hypersolvus granite, the transsolvus granitic melt was more evolved from the outset. The

423 evolution of this melt is monitored by the compositional differences between phenocryst cores

424 and rims. For example, $\mathrm{Ca}, \mathrm{Na}$ and $\mathrm{Al}$ concentrations decrease from core to rim (see Fig. 6,

425 Table 4). Decreasing $\mathrm{Ca}$ and $\mathrm{Al}$ concentrations mirror the evolution to a more alkaline magma

426 composition, which was caused by alkali feldspar fractionation (Boily and Williams-Jones, 
1994). The unexpected depletion of $\mathrm{Na}$ in the rims, however, is likely an artefact of the exsolution of a Na-rich fluid at a later stage of crystallization (Salvi and Williams-Jones, 1996; Roelofsen, 1997; Gysi et al., 2016), and/or the onset of albite crystallization. Not surprisingly, given the generally very low $\mathrm{Ca}$ and $\mathrm{Al}$ contents (close to zero) (Fig. 5a) and very high $\mathrm{Na}$ (Fig. $5 b)$ content of the amphibole, compared to those of the hypersolvus granite, the transsolvus granite is the most evolved of the intrusive units considered in this study. The enclaves in this unit contain amphibole with slightly higher $\mathrm{Ca}$, and $\mathrm{Al}$, and lower $\mathrm{K}$ and $\mathrm{F}$ concentrations than the crystals in the host granite (see Fig. 5), which points to a slightly less evolved composition. Nonetheless, their close compositional resemblance to the crystals of the transsolvus granite, indicates that they may be part of the same intrusion.

\subsection{Magma evolution monitored by the C-site occupation}

\subsubsection{Implications of the $\mathrm{Fe}^{2+} / \mathrm{Fe}^{3+}$ ratio}

The C-site of the amphibole-group minerals in the Strange Lake complex mainly hosts $\mathrm{Fe}^{2+}$ and $\mathrm{Fe}^{3+}$, but also $\mathrm{Li}^{+}, \mathrm{Mg}^{2+}, \mathrm{Mn}^{2+}, \mathrm{Zn}^{2+}, \mathrm{Ti}^{4+}$ and $\mathrm{Zr}^{4+}$ in significant proportions. The $\mathrm{Fe}^{2+} / \mathrm{Fe}^{3+}$ ratio of a magma is controlled by the $f \mathrm{O}_{2}$, and may be recorded by the amphibole composition. However, $\mathrm{Fe}^{3+}$ also becomes more or less compatible in the amphibole structure depending on its overall composition, and the exchange vectors that operate. In particular, the incorporation of $\mathrm{Na}$ at the expense of $\mathrm{Ca}$ is charge-balanced by $3+$ elements in the exchange vector: $\mathrm{Ca}+\left(\mathrm{Mg}, \mathrm{Fe}^{2+}\right)$ $=\mathrm{Na}+\left(\mathrm{Al}, \mathrm{Fe}^{3+}\right)$. When $\mathrm{Al}$ contents are depleted in the melt (e.g., increasing peralkalinity), $\mathrm{Fe}^{3+}$ becomes progressively more important in this exchange vector. In this case, the amphibole $\mathrm{Fe}^{2+} / \mathrm{Fe}^{3+}$ ratio will vary with the $\mathrm{Na} / \mathrm{Ca}$ ratio in rocks with the same major mineral paragenesis. In the late amphibole of the hypersolvus granite, $\mathrm{Fe}^{2+} / \mathrm{Fe}^{3+}$ ratios of the northern unit are lower 
and have higher $\mathrm{Na} / \mathrm{Ca}$ ratios than the amphibole of the southern unit (Fig. 9), which suggests that incorporation of $\mathrm{Fe}^{3+}$ in the structure, to some degree, was tied to the lower Ca content of the amphibole. However, as the correlation between $\mathrm{Fe}^{2+} / \mathrm{Fe}^{3+}$ and $\mathrm{Na} / \mathrm{Ca}$ is not $1: 1$, it is likely that there was an additional effect on the $\mathrm{Fe}^{2+} / \mathrm{Fe}^{3+}$ ratio, e.g., oxidation. Oxidation of a magma commonly occurs following fluid exsolution from the magma, due to decomposition of $\mathrm{H}_{2} \mathrm{O}$ to $\mathrm{H}_{2}$ and $1 / 2 \mathrm{O}_{2}$, and the subsequent loss of the much faster diffusing $\mathrm{H}_{2}$ (Czamanske and Wones, 1973). As the amphibole crystallized late in this facies, it can be inferred that the cooling intrusion had experienced some degassing and subsequent fluid loss at this point. Even in the freshest units (e.g., the hypersolvus granite) of the Strange Lake pluton, there is evidence of $\mathrm{H}_{2} \mathrm{O}$-saturation at a late stage of in-situ evolution, e.g., the albitization of $\mathrm{K}$-feldspar, the hydrothermal alteration of primary REE-minerals and the crystallization of hydrothermal REEphases, such as gagarinite-(Y) after fluorite (Gysi et al., 2016; Vasyukova and Williams-Jones, 2016).

The amphibole of the transsolvus granite and enclaves generally has a low $\mathrm{Fe}^{2+} / \mathrm{Fe}^{3+}$ ratio (see Fig. 5f). In addition, the phenocrysts rims have elevated $\mathrm{Fe}^{3+}$ concentrations compared to their cores (see Fig. 6c) which can be related to increasing $f \mathrm{O}_{2}$. The amphibole rims may have continued to crystallize after emplacement, when the magma experienced degassing and oxidation. In addition, some correlation between $\mathrm{Fe}^{2+} / \mathrm{Fe}^{3+}$ and $\mathrm{Na} / \mathrm{Ca}$ suggests that crystal chemical effects (high $\mathrm{Na} / \mathrm{Ca}$ ratio), partially caused the low $\mathrm{Fe}^{2+} / \mathrm{Fe}^{3+}$ ratio (Fig. 9). However, as the correlations are not $1: 1$, this indicates that a process, in addition to crystal chemical effects and oxidation, caused the high $\mathrm{Fe}^{3+}$ content. In peralkaline igneous systems, high concentrations of $\mathrm{F}^{-}$and $\mathrm{OH}^{-}$in the melt allow more $\mathrm{Fe}^{3+}$ to be present at a given $f \mathrm{O}_{2}$ (Birkett et al., 1996; Giehl et al., 2013). The high proportion of $\mathrm{Fe}^{3+}$ in the amphibole was likely caused by an increasing 
472 proportion of anions, notably $\mathrm{F}^{-}$and $\mathrm{OH}^{-}$in the evolving melt. This is manifested by significantly

473 higher $\mathrm{F}$ concentrations in the amphibole phenocrysts, compared to the amphiboles of the 474 hypersolvus granite (see Table 3).

475

476

477

478

479

480

481

482

483

\subsubsection{Titanium, manganese and zinc concentrations}

The titanium concentration of the amphibole-group minerals in alkaline rocks is an important indicator of the melt evolution owing to the incompatible nature of $\mathrm{Ti}$. Indeed $\mathrm{Ti}^{4+}$ was preferentially incorporated into the late crystallizing amphibole of the hypersolvus granite and much less so in the phenocrysts of the transsolvus granite (see Fig. 5c). From bulk rock compositions, we know that both the southern and northern hypersolvus granitic magmas were relatively enriched in $\mathrm{TiO}_{2}$ (on average, 0.3 wt. \% in both units). However, the amphibole of the southern unit has a much higher $\mathrm{TiO}_{2}$ concentration (avg. 1.5 wt. \%) than the northern unit (avg.1.1 wt. \%).

The proportion of the amphibole in each granite unit was estimated using the MINSQ excel spreadsheet of Herrmann and Berry (2002), which applies a least squares method to bulk rock and mineral compositions in order to determine the normative mineralogy of a sample. Proportions of the bulk $\mathrm{TiO}_{2}$ contributed by the mineral group were estimated from the amphibole proportion and the $\mathrm{TiO}_{2}$ content. The fine-grained southern hypersolvus granite contains $\sim 14$ wt. $\%$ amphibole, which hosts $\sim 70 \%$ of the bulk $\mathrm{TiO}_{2}$. The northern hypersolvus granite contains only $\sim 11$ wt. $\%$ amphibole, which hosts about $40 \%$ of the bulk $\mathrm{TiO}_{2}$. The remaining titanium is concentrated in aenigmatite and astrophyllite, sodium-titanosilicate minerals, which are present almost exclusively in the northern hypersolvus granite (see Fig. 2d). In the southern hypersolvus granite, the missing $30 \%$ is concentrated mostly in secondary 
astrophyllite, which occurs as inclusions in the alkali feldspar. Both the transsolvus granite and its enclaves have bulk rock $\mathrm{Ti}$ concentrations of $\sim 0.2$ wt. $\%$ and significantly lower concentrations in amphibole (0.7 and 0.9 wt. \%, respectively). As the amphibole is a phenocryst phase, it did not incorporate the relatively incompatible $\mathrm{Ti}^{4+}$. However, a slight increase in total Ti concentration from phenocryst cores to rims (avg. 0.09 to $0.1 \mathrm{apfu}$ ) is consistent with the internal evolution of this unit. In both the transsolvus granite and its enclaves, about $58 \%$ of the bulk $\mathrm{TiO}_{2}$ is hosted by the amphibole. The transsolvus granite has an elevated proportion of amphibole ( 18 wt. \%), whereas the enclaves contain much lower proportions of the mineral $(\sim 12$ wt. $\%)$, due to density separation that occurred in the magma chamber. The remaining $\mathrm{TiO}_{2}$ in this unit is concentrated mostly in the Na-Ti-silicate, narsarsukite.

Several studies have reported a strong positive correlation between $\mathrm{Ti}^{4+}$ and $\mathrm{O}^{2-}$ concentrations in amphibole, which is reflected in the relationships, ${ }^{\mathrm{C}} \mathrm{Ti}=\mathrm{Ti}$ and $\mathrm{O}^{2-}=2 \mathrm{Ti}^{4+}$ with the limit of ${ }^{\mathrm{W}}[2-$ $(\mathrm{OH}, \mathrm{F}, \mathrm{Cl})]$. This means, that if the $\mathrm{F}, \mathrm{Cl}$ and Ti concentrations of the amphibole are measured, and a maximum of 2 apfu for the $\mathrm{W}$-site is assigned, the $\mathrm{OH}-$ (and $\mathrm{O}-$ ) proportion can be estimated using the relationship $\mathrm{OH}=2-(2 \mathrm{Ti}-\mathrm{F}-\mathrm{Cl})$ (Hawthorne et al., 2012; King et al., 1999; Leake, 1968; Oberti et al., 2012). Following this protocol, hydroxyl $\left(\mathrm{OH}^{-}\right)$and oxygen $\left(\mathrm{O}^{2-}\right.$ ) are essential components of the amphibole from the southern hypersolvus granite (>1 apfu) (Fig. 10), whereas in the other, more evolved granite units, $\mathrm{F}^{-}$is the dominant $\mathrm{W}$-site anion (see Figs. 5h, 11b). Abundant fluorite inclusions in the amphibole of this unit (see Fig. 3a) indicate that fluorite saturated prior to the amphibole. This suggests that in the early and least evolved magma, the late amphibole crystallized from a water-rich, F-poor, residual magma. In the northern hypersolvus residual granitic melt, more $\mathrm{F}^{-}$, in addition to oxygen, was available to be incorporated in the amphibole (see Figs. 5h, Fig. 10). In both hypersolvus granite units (south 
517 and north), high $\mathrm{Ti}^{4+}$ concentrations required significant proportions of $\mathrm{O}^{2-}(0.2$ to 0.45 apfu) to 518 balance the higher charge of the $\mathrm{C}$ site. The phenocrysts of the transsolvus granite have high 519 proportions of $\mathrm{F}^{-}$, and low proportions of $\mathrm{O}^{2-}$ and $\mathrm{OH}^{-}$occupying the $\mathrm{W}$-site (see Fig. 5h, Fig. 10). This implies a highly F-enriched melt from the outset (phenocryst cores).

521 Elevated Mn-concentrations in the amphibole of the northern hypersolvus granite compared to those of amphibole in the fine-grained samples of the southern unit (see Fig. 5e) point to a progressive increase in $\mathrm{Mn}^{2+}$ concentration with hypersolvus granite evolution. The relatively 524 incompatible behavior of $\mathrm{Mn}^{2+}$ compared to $\mathrm{Fe}^{2+}$ was likely caused by the larger ionic radius of ${ }^{\mathrm{C}} \mathrm{Mn}^{2+}(\mathrm{r}=0.83 \AA)$ over $\mathrm{Fe}^{2+}(\mathrm{r}=0.78 \AA)$ (Hawthorne et al., 2001; Shannon, 1976). Amphibole $\mathrm{Zn}^{2+}$ concentrations decrease with hypersolvus granite differentiation (see Fig. 5g), due either to the co-crystallization of another $\mathrm{Zn}$-bearing phase or the progressive replacement of the relatively compatible $\mathrm{Zn}^{2+}$ ion by more incompatible cations, such as $\mathrm{Fe}^{3+}$. The amphibole phenocrysts of the transsolvus granite generally have low but highly variable $\mathrm{Mn}^{2+}$ - and $\mathrm{Zn}^{2+}$-concentrations, from 0 to $0.12 \mathrm{apfu}$, and 0.02 to $0.14 \mathrm{apfu}$, respectively. The latter is due to the much higher $\mathrm{Mn}$ and $\mathrm{Zn}$ concentrations of the phenocryst rims compared to the cores (see Table 4), which reflects increasing evolution of the magma. A progressive build-up in both $\mathrm{Mn}$ and $\mathrm{Zn}$ in the Strange Lake amphiboles with evolution was reported by Hawthorne et al. (2001), whereas we observe this trend separately for each granite unit.

\subsubsection{The role of lithium}

Lithium is a significant component of the Strange Lake amphiboles and has been reported to be an important constituent in alkali amphiboles of highly evolved alkaline rocks elsewhere (e.g., Hawthorne et al., 1993; Hawthorne et al., 1996; Marks et al., 2004). Owing to the incompatibility 
of lithium in common rock-forming minerals, its concentration reflects the degree of melt differentiation. The amphiboles of the Strange Lake pluton have an average Li concentration of $0.3 \mathrm{apfu}$, but concentrations reach $>1.0 \mathrm{apfu}$ in some transsolvus granite samples. Lithium concentrations of $>0.5$ apfu classify a sodic amphibole as ferro-ferri-(fluoro)-leakeite, which is the case for most of the amphibole in the more evolved units. Hawthorne et al. (2001), who reported $\mathrm{Li}$ concentrations of up to 0.4 apfu for amphibole in the most evolved members of the Strange Lake pluton, concluded that the elevated Li concentration was due to its high content in the magma rather than the structure of the mineral. The generally low content of $\mathrm{Li}$ in amphibole of both the southern and northern hypersolvus granite (avg. 0.16 and $0.31 \mathrm{wt} . \%$, respectively) compared to the transsolvus granite (avg. 0.58 wt. \%) (see Table 4), despite the fact that amphibole in the hypersolvus granite was a late crystallizing phase, suggests that the hypersolvus granite magma was relatively poor in Li. In contrast, the occurrence of ferro-ferri-(fluoro)leakeite as phenocrysts in the transsolvus granite suggests that the corresponding magma was more evolved. Of significance in this regard is the large range in Li-concentrations of the amphibole phenocrysts (0.1 to $1.2 \mathrm{apfu}$ ) (Fig. 11), which suggests that they record a large part of the evolution of the magma, a conclusion that is supported by the elevated Li concentrations of crystal rims relative to their cores (see Fig. 6d).

As noted earlier, the $\mathrm{Li}^{+}$concentration of the amphiboles correlates positively with the $\mathrm{C}$-site occupancy ( $\mathrm{R}^{2} \sim 0.8$ ), and hence knowledge of the concentration of this ion is essential to reliably evaluate the amphibole formula. In particular, the calculation of the $\mathrm{Fe}^{3+}$ concentration, which is highly dependent on $\mathrm{Li}^{+}$for charge balance, can only be performed accurately if the $\mathrm{Li}^{+}$ concentration is known (Hawthorne et al., 1993). The lithium concentration in the amphiboles correlates strongly with the $\mathrm{Fe}^{3+}$ concentration $\left(\mathrm{R}^{2}=0.92\right.$ for the transsolvus granite, $\mathrm{R}^{2}=0.83$ for 
562 the hypersolvus granite) (Fig. 11), and, with increasing degree of evolution, can be expressed by

563 the coupled substitution reaction

$$
{ }^{\mathrm{C}} \mathrm{Fe}^{2+}+{ }^{\mathrm{C}} \mathrm{Fe}^{2+} \rightarrow{ }^{\mathrm{C}} \mathrm{Fe}^{3+}+{ }^{\mathrm{C}} \mathrm{Li}^{+}
$$

565 The progressive increase in $\mathrm{Li}^{+}$and $\mathrm{Fe}^{3+}$ with evolution is consistent with the increase in $f \mathrm{O}_{2}$ in 566 the hypersolvus granite, and also with the increase in melt $\mathrm{F}^{-}$and $\mathrm{OH}^{-}$in the transsolvus granite, 567 both of which were discussed earlier.

\subsection{Distribution of the REE and other trace elements}

The trace element composition of amphibole-group minerals is a function of the magma composition and the structure of the mineral (i.e., the preference of its sites for ions of a particular size and charge). In the Strange Lake granites, for example, the negative $\mathrm{Ba}, \mathrm{Pb}, \mathrm{Sr}$, and $\mathrm{Eu}$ anomalies in both the amphibole and bulk rock are likely due to voluminous plagioclase fractionation early in the crystallization history. This process is interpreted to have produced the large Mesoproterozoic anorthosite complexes of the Nain Plutonic Suite (Emslie et al., 1994; McLelland et al., 2010). Consistently low Rb concentrations, and negative U and Y anomalies in the amphibole, but not in bulk rock, on the other hand, are interpreted to have been caused by within-pluton-fractionation of $\mathrm{K}$-feldspar (substitution of $\mathrm{Rb}$ for $\mathrm{K}$ ) and of $\mathrm{Y}$ - and U-rich minerals, such as gagarinite-(Y), the fluorite-fluocerite solid solution and small amounts of Ubearing thorite.

The behavior of the REE in amphibole-group minerals is governed by a combination of crystal

581 chemical constraints and magmatic processes. Several studies have concluded that the trace element composition of amphibole is dependent on the major element distribution, and, to a lesser extent, on the $\mathrm{P}, \mathrm{T}$ and $\mathrm{fO}_{2}$ conditions (Bottazzi et al., 1999; Dalpé and Baker, 2000). In 
the Gardar Province (Ilímaussaq, Puklen and Grønnedal-Ika intrusions), for example, Ca-rich amphibole- group minerals are strongly enriched in the LREE (order of magnitude), compared to the Na-rich members of the same mineral group (Marks et al., 2004). Consistent with this observation, the Ca-rich ferro-ferri-katophorite at Strange Lake is enriched in the REE by $10^{2}$ to $10^{3}$ times the chondrite values, whereas the Na-rich fluor-arfvedsonite and ferro-ferri-(fluoro)leakeite have much lower total REE concentrations, and show a stronger relative enrichment in the HREE (see Fig. 8). The Ca-rich amphiboles are members of the earlier, less evolved hypersolvus granite, in which they crystallized as a late, interstitial phase from a small proportion of residual liquid. The residual liquid of this overall less evolved unit was relatively enriched in incompatible elements such as the REE, whereas the amphibole phenocrysts of the more evolved transsolvus granite crystallized from a relatively 'dilute' magma with low incompatible element concentrations. In contrast, the amphiboles of the Gardar Province all are late, near solidus phases in all rock types that have been investigated, e.g., augite-syenites, alkali granites, agpaites and nepheline syenites (Markl et al., 2001; Marks et al., 2004). Thus, the fact that the LREE are tied to Ca-rich amphiboles implies that another factor, in addition to the magma composition, may have been important in accommodating the REE in the crystal structure. Rare earth element concentrations in the Strange Lake amphiboles correlate positively with $\mathrm{Al}^{3+}\left(\mathrm{R}^{2}=0.59\right)$ and $\mathrm{Ca}^{2+}\left(\mathrm{R}^{2}=0.61\right)$ concentrations, and negatively with $\mathrm{Na}^{+}\left(\mathrm{R}^{2}=0.57\right), \mathrm{F}^{-}\left(\mathrm{R}^{2}=0.51\right)$ (Fig. 12) and $\mathrm{Si}^{4+}$ concentrations. This suggests that overall the REE become less compatible in the amphibole 604 structure with increasing degree of magma evolution, or alternatively, that the nature of the major elements in the mineral structure control the accommodation of the REE. 
606 Interestingly, the amphiboles of the oikocrystic and pegmatitic samples of the southern

607 hypersolvus granite have much lower REE concentrations (avg. 0.04 wt. \%) than their host

608 (avg. 0.16 wt. \%), but similar to those of amphiboles in the northern hypersolvus granite (avg.

$609 \sim 0.07$ wt. \%) (see Table 3). In the latter amphiboles, however, the Al and Ca contents are

610 significantly lower ( 0.5 vs 1.0 wt. $\% \mathrm{Al}_{2} \mathrm{O}_{3}$ and 0.5 vs. 1.1 wt. \% $\left.\mathrm{CaO}\right)$. This is consistent with

611 the interpretation that the oikocrystic and pegmatitic granites crystallized from volatile-rich melt

612 pockets that evolved in-situ, and is further evidence that the northern hypersolvus granite

613 evolved from the southern hypersolvus granite. The decoupling of REE concentrations from

614 those of $\mathrm{Ca}$ and $\mathrm{Al}$ observed in these two rock units speaks to a factor other than the degree of

615 magma evolution in controlling the incorporation of the REE in amphibole.

616

617

619

620

621

622

\subsection{REE inter-site partitioning}

Previous studies have concluded that the REE in the amphibole structure are distributed over the $\mathrm{B}$ and $\mathrm{C}$ sites and that this distribution depends on the nature of the major elements that reside in these sites (Bottazzi et al., 1999; Tiepolo et al., 2007; Tiepolo et al., 2000). These conclusions were reached from studies of the partitioning of the REE between amphibole and melt, with the $\mathrm{D}_{\mathrm{REE}}$ showing systematic behavior controlled by the $\mathrm{B}$ and $\mathrm{C}$ site dimensions ( $c f$. Blundy and Wood, 2003). Unfortunately, these data do not extend to the amphibole compositions encountered at Strange Lake. In order to obtain a first-order estimate of the localization of the REE in sodic amphibole, apparent mineral-melt partition coefficients were calculated from the bulk rock and median sodic amphibole compositions of transsolvus granite sample 204720 . Amphibole was the first major phase to crystallize in this sample, but inclusions of pyrochlore group minerals and monazite-(Ce) indicate that these minerals had likely already saturated. The median compositions of these minerals at their respective modes were subtracted from the bulk 
composition to obtain an estimate of the melt composition at the time of amphibole crystallization. This assumes that sample 204720 acted as a closed system, that it represents a melt composition, that all pyrochlore group minerals and monazite-(Ce) crystallized prior to amphibole, and that all amphibole formed at the same time. However, deviations from these assumptions mainly impact the absolute D values, whereas their systematics are unaffected.

A plot of the partition coefficients against the radii of the REE (6-fold and 8-fold coordinated radii for the C and B-sites, respectively, as given in Shannon 1976) is shown in Fig. 13. The LREE in the sodic amphiboles from Strange Lake are most compatible with the B-site (Fig. 13), as also has been shown for calcic and sodic-calcic amphiboles (Bottazzi et al., 1999). The lightest of the lanthanides, $\mathrm{La}$ and $\mathrm{Ce}$, which have ionic radii of $1.16 \AA$ and $1.14 \AA$ (at 8-fold coordination) are closest to the ideal radius of the B-site and are thus preferentially incorporated. For reference, the major elements occupying this site are $\mathrm{Na}$ and $\mathrm{Ca}$, which with ionic radii of $1.12 \AA$ and $1.18 \AA$, respectively, are slightly smaller or larger than the ideal radius. The HREE, which have ionic radii between 0.86 to $0.94 \AA$, on the other hand, are compatible with the 6 -fold coordinated $\mathrm{C}$-site, and their compatibility increases exponentially with increasing atomic number (Fig. 13). Thus, the 'heaviest' of the REE, $\mathrm{Yb}$ and $\mathrm{Lu}$ are preferentially incorporated in the crystal structure ( $D^{\text {amph-bulk }} \mathrm{Yb}, \mathrm{Lu}>1.0$ ), which, indeed, is what is observed in the chondritenormalized REE profiles (Fig. 7). The middle REE, e.g., Gd, has the lowest apparent partition coefficient as its radius is furthest from that of the ideal radii of both the B and $\mathrm{C}$ sites and hence fits in neither site (in Fig. 13 it is shown at its 6-fold coordinated radius). The apparent D values also suggest that $D_{\text {LREE }}<D_{\text {HREE }}$, in agreement with Tiepolo et al. (2000), who showed that the LREE are incompatible in amphibole $\left(\mathrm{D}_{\mathrm{La}}^{\mathrm{amph} / 1}=0.06\right.$ to 0.5$)$, whereas the HREE are relatively 
651 compatible $\left(\mathrm{D}^{\mathrm{amph} / \mathrm{l}} \mathrm{Yb}=0.25\right.$ to 2.0$)$. The apparent (calculated) $\mathrm{D}^{\text {amph-bulk }}$ and ionic radii at 6- and 8-fold coordination are given in Table 6 .

\subsection{The role of amphibole in concentrating HREE in the pluton}

A significant proportion of the bulk REE content of the Strange Lake granites is contained in amphibole. Indeed, the REE content of amphibole in both fine-grained and oikocrystic and pegmatitic samples of the southern hypersolvus granite is similar to or exceeds that of the bulk rock, except for $\mathrm{La}$ and $\mathrm{Ce}$; the contents of the heaviest of the REE, $\mathrm{Yb}$ and $\mathrm{Lu}$, are four times higher than in the bulk rock.

Proportions of the bulk REE hosted by the mineral group were estimated from the proportion of the amphibole in each granite facies and the REE contents of the corresponding amphiboles. The amphibole of the southern hypersolvus granite (fine-grained) ( $14 \mathrm{wt} . \%)$ contains about $10 \%$ of the bulk LREE (avg. 0.1 wt. \%) and more than $35 \%$ of the bulk HREE (avg. 0.01 wt. \%) (Fig. 14). In the case of $\mathrm{Yb}$ and $\mathrm{Lu}$, the proportions increase to 55 and $70 \mathrm{wt} \%$, respectively. In the northern hypersolvus granite, REE concentrations are considerably lower than the bulk rock concentrations, except for Tm, Yb and Lu. On average, $2 \%$ of the bulk LREE (avg. 0.15 wt. \%), and $17 \%$ of the bulk HREE (avg. 0.02 wt. \%) are hosted by amphibole in this unit ( 11 wt. \%) (Fig. 14). As the bulk rock LREE concentrations of this unit are relatively high $\left(\sim 10^{3}\right.$ times chondrite values), this points to a major LREE bearing phase, e.g., monazite-(Ce), and/or pyrochlore group minerals having crystallized prior to the amphibole or that there was another sink for the LREE. The latter would be consistent with the findings of Vasyukova and WilliamsJones $(2014,2016)$ that the hypersolvus granite magma saturated with (exsolved) a fluoride liquid into which the LREE partitioned preferentially. 
Amphibole proportions in the transsolvus granite are relatively high ( $18 \mathrm{wt} . \%)$, whereas their REE concentrations are particularly low $(>1$ and $<100$ times the chondrite value). In this unit, only $0.1 \%$ of the bulk LREE (avg. 0.28 wt. \%) and $4 \%$ of the HREE (avg. 0.03 wt. \%), on average, are hosted by the amphibole (Fig. 14). As the amphiboles occur as phenocrysts in the transsolvus granite, they largely record information about the pre-emplacement composition of the magma. Given the low LREE content of the amphibole, it is possible that an early fractionating phase depleted the melt in the LREE. These phases were monazite-(Ce) and gagarinite-(Ce), which crystallized prior to or contemporaneously with the amphibole.

As mentioned earlier, some of the enclaves hosted by the transsolvus granite are interpreted to represent the quenched margin of this intrusion. Accordingly, amphibole phenocrysts in these enclaves and the host intrusion should have similar compositions. Indeed, their major element concentrations match closely those of the transsolvus granite (see Fig. 5). However, the light and middle REE contents of the amphiboles from the enclaves are generally higher than those of amphiboles in their host (see Fig. 7e); the chondrite-normalized profiles of the bulk enclaves are parallel to those of the bulk host granite, but their absolute values are slightly lower. The consistently higher light and middle REE concentrations of amphibole in the enclaves compared to their host could indicate that the amphibole crystallized from a melt relatively enriched in these elements. However, much of the amphibole in the enclaves crystallized after emplacement (quenching), which means that it crystallized from the very first and least evolved transsolvus granite magma (lower bulk REE profile, see Fig. 7e). We therefore suggest that amphibole in the enclaves crystallized slightly later than the phenocrysts in the magma chamber (transsolvus granite), resulting in an amphibole more enriched in the REE. 
The amphibole in the more altered localities of the transsolvus granite was replaced extensively by aegirine and/or hematite during hydrothermal alteration (Gysi and Williams-Jones, 2013; Gysi et al., 2016; Salvi and Williams-Jones, 1990, 1996; Vasyukova et al., 2016). As the REE content of the aegirine is orders of magnitude lower than that of the amphibole, it is very likely that the replacement of amphibole by aegirine (and hematite) led to the release of the REE, particularly the HREE to the hydrothermal fluid and the development of potentially exploitable zones of HREE mineralization.

\section{CONCLUSIONS}

We have shown that the major and trace-element compositions of amphiboles of the Strange Lake granite complex reflect the magmatic evolution of the pluton. The differentiation of the magma proceeded from the southern hypersolvus granite to the more evolved northern hypersolvus granite, two separate intrusions which both contain amphibole as a late, interstitial phase (Fig. 15a). The most evolved unit, a transsolvus granite, contains early crystallizing amphibole in the form of phenocrysts (Fig. 15b). Amphibole compositions vary from calcicsodic (ferro-ferri-katophorite) in the least evolved southern hypersolvus granite to sodic members ((fluoro)-arfvedsonite, ferro-ferri-(fluoro)-leakeite) in the other, more evolved granites.

The increasing $\mathrm{Fe}^{3+}$ concentration in amphibole with hypersolvus granite evolution was a result of crystal chemical effects ( $\mathrm{Na} / \mathrm{Ca}$ proportion) and increasing $f \mathrm{O}_{2}$ through degassing. The same trend in the phenocrysts of the transsolvus granite implies a higher compatibility of $\mathrm{Fe}^{3+}$ with increasing $\mathrm{Na} / \mathrm{Ca}$ proportions and an increase in $\mathrm{OH}^{-}$and $\mathrm{F}^{-}$concentrations in the evolving melt. Variations in Ti-concentrations indicate the presence of Na-Ti-silicates, such as aenigmatite, astrophyllite and narsarsukite, which replaced the amphibole to varying degrees in each unit. In the transsolvus granite, magma evolution is manifested by increasing $\mathrm{Ti}$, $\mathrm{Mn}$ and $\mathrm{Zn}$ 
concentrations from amphibole cores to rims. The phenocrysts of the transsolvus granite also contain significant $\mathrm{Li}$ (ferro-ferri-fluoro-leakeite) that correlates positively with $\mathrm{Fe}^{3+}$, indicating that this most evolved melt was already enriched in Li at an early stage.

The amphiboles of all units are enriched in $\mathrm{Nb}, \mathrm{Zr}$ and $\mathrm{Hf}$ and the HREE compared to the bulk rock, reflecting a combination of magmatic compositional and crystal chemical effects. In the hypersolvus granite, the late crystallization of amphiboles from a small proportion of residual magma resulted in high incompatible element concentrations, whereas the early crystallization of amphiboles in the transsolvus granite ensured relatively low concentrations of these elements, despite the overall more evolved nature of the magma. The concentrations of the relatively incompatible LREE $\left(\mathrm{D}_{\text {arf-bulk }}<0.01\right)$ are positively coupled to the amphibole Ca concentration, with the LREE preferentially incorporated in the larger B-site. The HREE were preferred by the C-site and increased in compatibility $\left(\mathrm{D}_{\text {arf/bulk }}>0.1\right)$ with increasing atomic number and decreasing ionic radius. Variations in the LREE concentrations of the amphiboles were controlled by the relative timing of crystallization of amphibole and the presence of primary LREE minerals, such as monazite-(Ce), pyrochlore group minerals and gagarinite-(Ce), as well as the exsolution of a LREE-rich fluoride melt. The uptake of the HREE by amphibole was controlled by their relative compatibility in the structure of this mineral due to their smaller radii. A significant proportion of the bulk HREE content of the Strange Lake granites was carried by the amphibole, which during subsequent hydrothermal alteration was released to the fluid and contributed to the development of potentially exploitable HREE mineralization.

\section{ACKNOWLEDGEMENTS}

A grant by Quest Rare Minerals Ltd. and a matching grant from the NSERC Collaborative Research and Development Program, both to A. E. Williams-Jones, provided financial support 
741 for this study. Quest Rare Minerals Ltd. granted access to the field area, drill core, logistical 742 support and assay data. The sample suite used for this study included outcrop samples collected 743 by Alexandre Brosseau-Liard and Robert Fritscher. Discussions with Robert F. Martin and 744 Jeanne Paquette contributed greatly to our understanding of the amphibole chemistry. Olga 745 Vasyukova provided valuable insights into the evolution of the Strange Lake magma from her 746 own research on the pluton. Lang Shi, André Poirier, Bill Minarik and Anna Jung provided 747 essential support by guiding the mineral chemical analyses and helping in the interpretation of 748 the results. The manuscript benefited considerably from thoughtful reviews by Massimo Tiepolo 749 and Kathryn Goodenough. 


\section{REFERENCES}

Abdel-Rahman, A. F. M., 1994, Alkali Amphibole: A Potential Source of Rare Earth Elements in Felsic Alkaline Rocks: Exploration and Mining Geology, v. 3, no. 2, p. 81-94.

Birkett, T. C., Trzcienski, W. E., and Stirling, J. A. R., 1996, Occurrence and compositions of some Ti-bearing minerals in the Strange Lake intrusive complex, Quebec-Labrador boundary: Canadian Mineralogist, v. 34, p. 779-801.

Blundy, J., and Wood, B., 2003, Partitioning of trace elements between crystals and melts: Earth and Planetary Science Letters, v. 210, no. 3-4, p. 383-397.

Boily, M., and Williams-Jones, A. E., 1994, The role of magmatic and hydrothermal processes in the chemical evolution of the Strange Lake plutonic complex, Quebec-Labrador: Contributions to Mineralogy and Petrology, v. 118, no. 1, p. 33-47.

Bottazzi, P., Tiepolo, M., Vannucci, R., Zanetti, A., Brumm, R., Foley, S. F., and Oberti, R., 1999, Distinct site preferences for heavy and light REE in amphibole and the prediction of D-Amph/L(REE): Contributions to Mineralogy and Petrology, v. 137, no. 1-2, p. 3645.

Camara, F., Hawthorne, F. C., Ball, N. A., Bekenova, G., Stepanov, A. V., and Kotel'nikov, P. E., 2010, Fluoroleakeite, NaNa2(Mg2Fe23+Li)Si8O22F2, a new mineral of the amphibole group from the Verkhnee Espe deposit, Akjailyautas Mountains, Eastern Kazakhstan District, Kazakhstan: description and crystal structure: Mineralogical Magazine, v. 74, no. 3, p. 521-528.

Czamanske, G. K., and Dillet, B., 1988, Alkali amphibole, tetrasilicic mica, and sodic pyroxene in peralkaline siliceous rocks, Questa Caldera, New Mexico: American Journal of Science, v. 288-A, no. 1988, p. 358-392. 
Czamanske, G. K., and Wones, D. R., 1973, Oxidation during Magmatic Differentiation, Finnmarka Complex, Oslo Area, Norway .2. Mafic Silicates: Journal of Petrology, v. 14, no. 3, p. 349-380.

Dalpé, C., and Baker, D. R., 2000, Experimental investigation of large-ion-lithophile-element-, high-field-strength-element- and rare-earth-element-partitioning between calcic amphibole and basaltic melt: the effects of pressure and oxygen fugacity: Contributions to Mineralogy and Petrology, v. 140, no. 2, p. 233-250.

Davidson, A., 1982, Petrochemistry of the Blachford Lake Complex near Yellowknife, Northwest Territories.: Maurice, E. T. (ed.) Uranium in Granites. Geological Survey of Canada, p. 71-79.

Emslie, R. F., Hamilton, M. A., and Theriault, R. J., 1994, Petrogenesis of a Midproterozoic anorthosite-mangerite-charnockite-granite (AMCG) complex - isotopic and chemical evidence from the Nain Plutonic Suite: Journal of Geology, v. 102, no. 5, p. 539-558.

Emslie, R. F., and Stirling, J. A. R., 1993, Rapakivi and Related Granitoids of the Nain Plutonic Suite - Geochemistry, Mineral Assemblages and Fluid Equilibria: Canadian Mineralogist, v. 31 , p. $821-847$.

Giehl, C., Marks, M., and Nowak, M., 2013, Phase relations and liquid lines of descent of an iron-rich peralkaline phonolitic melt: an experimental study: Contributions to Mineralogy and Petrology, v. 165, no. 2, p. 283-304.

Giret, A., Bonin, B., and Leger, J. M., 1980, Amphibole Compositional Trends in Oversaturated and Undersaturated Alkaline Plutonic Ring-Complexes: Canadian Mineralogist, v. 18, p. 481-495. 
804

805

806

807

Gower, C. F., and Krogh, T. E., 2002, A U-Pb geochronological review of the Proterozoic history of the eastern Grenville Province: Canadian Journal of Earth Sciences, v. 39, no. 5, p. $795-829$.

Gysi, A. P., and Williams-Jones, A. E., 2013, Hydrothermal mobilization of pegmatite-hosted REE and $\mathrm{Zr}$ at Strange Lake, Canada: A reaction path model: Geochimica et Cosmochimica Acta, v. 122, no. 2013, p. 324-352.

Gysi, A. P., Williams-Jones, A. E., and Collins, P., 2016, Lithogeochemical Vectors for Hydrothermal Processes in the Strange Lake Peralkaline Granitic REE-Zr-Nb-Deposit: Economic Geology and the Bulletin of the Society of Economic Geologists, v. 111, p. 1241-1276.

Hawthorne, F. C., 1976, The crystal chemistry of amphiboles: V. the structure and chemistry of arfvedsonite: Canadian Mineralogist, v. 14, p. 346-356.

Hawthorne, F. C., Oberti, R., Cannillo, E., Ottolini, L., Roelofsen, J. N., and Martin, R. F., 2001, Li-bearing arfvedsonitic amphiboles from the Strange Lake peralkaline granite, Quebec: Canadian Mineralogist, v. 39, p. 1161-1170.

Hawthorne, F. C., Oberti, R., Harlow, G. E., Maresch, W. V., Martin, R. F., Schumacher, J. C., and Welch, M. D., 2012, Nomenclature of the amphibole supergroup: American Mineralogist, v. 97 , no. 11-12, p. 2031-2048.

Hawthorne, F. C., Oberti, R., Ottolini, L., and Foord, E. E., 1996, Lithium-bearing fluorarfvedsonite from Hurricane Mountain, New Hampshire: A crystal-chemical study: Canadian Mineralogist, v. 34, p. 1015-1019. 
Hawthorne, F. C., Ungaretti, L., Oberti, R., Bottazzi, P., and Czamanske, G. K., 1993, Li - an Important Component in Igneous Alkali Amphiboles: American Mineralogist, v. 78, no. 7-8, p. 733-745.

Herrmann, W., and Berry, R. F., 2002, MINSQ - a least squares spreadsheet method for calculating mineral proportions from whole rock major element analyses: Geochemistry: Exploration, Environment, Analysis, v. 2, no. 4, p. 361-368.

James, D. T., and Dunning, G. R., 2000, U-Pb geochronological constraints for paleoproterozoic evolution of the core zone, southeastern Churchill Province, northeastern laurentia: Precambrian Research, v. 103, no. 1-2, p. 31-54.

Kerr, A., and Rafuse, H., 2012, Rare-earth element (REE) geochemistry of the Strange Lake deposits: Implications for resource estimation and metallogenic models.: Current Research (2012) Newfoundland and Labrador Department of Natural Resources, v. 1, p. 39-60.

King, P. L., Hervig, R. L., Holloway, J. R., Vennemann, T. W., and Righter, K., 1999, Oxysubstitution and dehydrogenation in mantle-derived amphibole megacrysts: Geochimica Et Cosmochimica Acta, v. 63, no. 21, p. 3635-3651.

Konopleva, N. G., Ivanyuk, G. Y., Pakhomovsky, Y. A., Yakovenchuk, V. N., Men'shikov, Y. P., and Korchak, Y. A., 2008, Amphiboles of the Khibiny alkaline pluton, Kola Peninsula, Russia: Geology of Ore Deposits, v. 50, no. 8, p. 720-731.

Kovalenko, V. I., Tsaryeva, G. M., Goreglyad, A. V., Yarmolyuk, V. V., Troitsky, V. A., Hervig, R. L., and Farmer, G. L., 1995, The Peralkaline Granite-Related Khaldzan-Buregtey Rare-Metal (Zr, Nb, Ree) Deposit, Western Mongolia: Economic Geology and the Bulletin of the Society of Economic Geologists, v. 90, no. 3, p. 530-547. 
Leake, B. E., 1968, A Catalog of Analyzed Calciferous and Subcalciferous Amphiboles Together with Their Nomenclature and Associated Minerals: Geological Society of America, Special Papers 1968, v. 98, p. 1-44.

Leake, B. E., Woolley, A. R., Arps, C. E. S., Birch, W. D., Gilbert, M. C., Grice, J. D., Hawthorne, F. C., Kato, A., Kisch, H. J., Krivovichev, V. G., Linthout, K., Laird, J., Mandarino, J. A., Maresch, W. V., Nickel, E. H., Rock, N. M. S., Schumacher, J. C., Smith, D. C., Stephenson, N. C. N., Ungaretti, L., Whittaker, E. J. W., and Guo, Y. Z., 1997, Nomenclature of amphiboles: Report of the subcommittee on amphiboles of the International Mineralogical Association, Commission on New Minerals and Mineral Names: Canadian Mineralogist, v. 35, p. 219-246.

Locock, A. J., 2014, An Excel spreadsheet to classify chemical analyses of amphiboles following the IMA 2012 recommendations: Computers \& Geosciences, v. 62, p. 1-11.

Ltd., Q. R. M., 2012, Quest announces that a revised resource estimate for the Strange Lake BZone REE deposit shows a doubling of tonnage, http://questareminerals.com/news.php, Volume 2016: Toronto, Quest Rare Minerals Ltd.

Markl, G., Marks, M., Schwinn, G., and Sommer, H., 2001, Phase equilibrium constraints on intensive crystallization parameters of the Ilimaussaq complex, South Greenland: Journal of Petrology, v. 42, no. 12, p. 2231-2258.

Marks, M., Halama, R., Wenzel, T., and Markl, G., 2004, Trace element variations in clinopyroxene and amphibole from alkaline to peralkaline syenites and granites: implications for mineral-melt trace-element partitioning: Chemical Geology, v. 211, no. 3-4, p. 185-215. 
Mayer, B., Jung, S., Romer, R. L., Pfander, J. A., Klugel, A., Pack, A., and Groner, E., 2014, Amphibole in alkaline basalts from intraplate settings: implications for the petrogenesis of alkaline lavas from the metasomatised lithospheric mantle: Contributions to Mineralogy and Petrology, v. 167, no. 989.

McLelland, J. M., Selleck, B. W., Hamilton, M. A., and Bickford, M. E., 2010, Late- to posttectonic setting of some major proterozoic anorthosite - mangerite - charnockite - granite (AMCG) suites: Canadian Mineralogist, v. 48, no. 4, p. 729-750.

Miller, R. R., 1996, Structural and textural evolution of the Strange Lake peralkaline rareelement (NYF) granitic pegmatite, Quebec-Labrador: Canadian Mineralogist, v. 34, p. 349-371.

Miller, R. R., Heaman, L. M., and Birkett, T. C., 1997, U-Pb zircon age of the Strange Lake peralkaline complex: Implications for Mesoproterozoic peralkaline magmatism in northcentral Labrador: Precambrian Research, v. 81, no. 1-2, p. 67-82.

Mungall, J. E., and Martin, R. F., 1996, Extreme differentiation of peralkaline rhyolite, Terceira, Azores: A modern analogue of Strange Lake, Labrador?: Canadian Mineralogist, v. 34, p. 769-777.

Oberti, R., Cannillo, E., and Toscani, G., 2012, How to name amphiboles after the IMA2012 report: rules of thumb and a new PC program for monoclinic amphiboles: Periodico Di Mineralogia, v. 81, no. 2, p. 257-267.

Petrella, L., Williams-Jones, A. E., Goutier, J., and Walsh, J., 2014, The Nature and Origin of the Rare Earth Element Mineralization in the Misery Syenitic Intrusion, Northern Quebec, Canada: Economic Geology, v. 109, no. 6, p. 1643-1666. 
Piilonen, P. C., Mcdonald, A. M., Poirier, G., Rowe, R., and Larsen, A. O., 2013, Mafic Minerals of the Alkaline Pegmatites in the Larvik Plutonic Complex, Oslo Rift, Southern Norway: Canadian Mineralogist, v. 51, no. 5, p. 735-770.

Pillet, D., Chenevoy, M., and Belanger, M., 1992, Petrology of Peralkaline Granite from Lake Brisson (Central Labrador, Nouveau-Quebec) .1. Intrusion and Chemical Evolution: Canadian Journal of Earth Sciences, v. 29, no. 2, p. 353-372.

-, 1993, Petrology of Peralkaline Granite from Lake Brisson (Quebec-Labrador) .2. Mineralogy and Modes of Crystallization: Canadian Journal of Earth Sciences, v. 30, no. 12, p. 24232435.

Roelofsen, J. N., 1997, The primary and secondary mafic silicates of two alkaline anorogenic complexes: Strange Lake (Québec-Labrador) and Amba Dongar (Gujarat, India) [Ph.D.: McGill University, $321 \mathrm{p}$.

Salvi, S., and Williams-Jones, A. E., 1990, The Role of Hydrothermal Processes in the GraniteHosted Zr, Y, Ree Deposit at Strange Lake, Quebec Labrador - Evidence from Fluid Inclusions: Geochimica et Cosmochimica Acta, v. 54, no. 9, p. 2403-2418.

Salvi, S., and Williams-Jones, A. E., 1992, Reduced Orthomagmatic C-O-H-N-Nacl Fluids in the Strange Lake Rare-Metal Granitic Complex, Quebec Labrador, Canada: European Journal of Mineralogy, v. 4, no. 5, p. 1155-1174.

Salvi, S., and Williams-Jones, A. E., 1996, The role of hydrothermal processes in concentrating high-field strength elements in the Strange Lake peralkaline complex, northeastern Canada: Geochimica et Cosmochimica Acta, v. 60, no. 11, p. 1917-1932. 
Salvi, S., and Williams-Jones, A. E., 1997, Fischer-Tropsch synthesis of hydrocarbons during sub-solidus alteration of the Strange Lake peralkaline granite, Quebec/Labrador, Canada: Geochimica Et Cosmochimica Acta, v. 61, no. 1, p. 83-99.

Salvi, S., and Williams-Jones, A. E., 2006, Alteration, HFSE mineralisation and hydrocarbon formation in peralkaline igneous systems: Insights from the Strange Lake Pluton, Canada: Lithos, v. 91, p. 19-34.

Shannon, R. D., 1976, Revised Effective Ionic-Radii and Systematic Studies of Interatomic Distances in Halides and Chalcogenides: Acta Crystallographica Section A, v. 32, no. Sep1, p. 751-767.

Sun, S. S., and McDonough, W. F., 1989, Chemical and isotopic systematics of oceanic basalts: implications for mantle composition and processes: Geological Society, London, Special Publications, v. 42, p. 313-345.

Tiepolo, M., Oberti, R., Zanetti, A., Vannucci, R., and Foley, S. F., 2007, Trace-element partitioning between amphibole and silicate melt: Amphiboles: Crystal Chemistry, Occurrence, and Health Issues, v. 67, p. 417-451.

Tiepolo, M., Vannucci, R., Bottazzi, P., Oberti, R., Zanetti, A., and Foley, S., 2000, Partitioning of rare earth elements, $\mathrm{Y}, \mathrm{Th}, \mathrm{U}$, and $\mathrm{Pb}$ between pargasite, kaersutite, and basanite to trachyte melts: Implications for percolated and veined mantle: Geochemistry Geophysics Geosystems, v. 1.

Tuttle, O. F., and Bowen, N. L., 1958, Origin of granite in the light of experimental studies in the system $\mathrm{NaAlSi}_{3} \mathrm{O}_{8}-\mathrm{KAlSi}_{3} \mathrm{O}_{8}-\mathrm{SiO}_{2}-\mathrm{H}_{2} \mathrm{O}$, Geological Society of America, Memoir 74, 146 p.: 
926 Vasyukova, O., and Williams-Jones, A. E., 2014, Fluoride-silicate melt immiscibility and its role in REE ore formation: Evidence from the Strange Lake rare metal deposit, Que'becLabrador, Canada: Geochimica et Cosmochimica Acta, v. 139, no. 2014, p. 110-130.

929 -, 2016, The evolution of immiscible silicate and fluoride melts: Implications for REE oregenesis: Geochimica et Cosmochimica Acta, v. 172, p. 205-224.

931 Vasyukova, O. V., Williams-Jones, A. E., and Blamey, N. J. F., 2016, Fluid evolution in the Geology, v. 444, p. 83-100. 
Fig. 1: A geological map of the Strange Lake pluton showing the distribution of the major lithological units. Locations of the samples used in this study are indicated.

Fig. 2: Thin section photomicrographs showing a) amphibole in hypersolvus granite (Arf), occupying interstices between alkali-feldspar (perthite) (Afs) and quartz (Qtz) (ppl view), b) amphibole in hypersolvus granite showing swapped margin texture with alkali-feldspar (ppl), c) interstitial amphibole in the northern hypersolvus granite that has been largely replaced by aenigmatite (red) (Aen) and astrophyllite (orange) (Ast) (xpl) and d) a Li-bearing amphibole (Lea) phenocryst in transsolvus granite that has been partly replaced by aegirine (Aeg) along its $944 \operatorname{rim}(\mathrm{ppl})$.

Fig. 3: Backscattered electron images of Strange Lake amphibole-group minerals showing a) arfvedsonite with one large and numerous small fluorite $(\mathrm{Fl})$ and fluorite-fluocerite solid solution (Fl-Flc) (brighter) inclusions (hypersolvus granite), b) amphibole interstitial to perthitic alkali feldspar and quartz (hypersolvus granite), replaced by fibrous astrophyllite along the rim, c) an euhedral Li-bearing alkali amphibole (ferro-ferri-fluoro-leakeite) crystal (transsolvus granite) containing numerous microcline $(\mathrm{Mc})$ and albite $(\mathrm{Ab})$ inclusions and, d) small subhedral amphibole crystals among K-feldspar (Ksp) and quartz crystals (enclave).

Fig. 4: Ternary diagrams showing a) the A-and B-site occupancy of the sodic-calcic to sodic amphibole-group minerals of the Strange Lake pluton (in apfu) (note that theoretically, endmember arfvedsonite can have any composition along the $\mathrm{Na}-\mathrm{K}$ tie-line), and b) the $\mathrm{C}$-site occupation of the amphibole-group minerals. The diagram (b) organizes the compositional data according to the valence state of the cations, where $\mathrm{R}^{+}={ }^{\mathrm{C}} \mathrm{Li}^{+}, \mathrm{R}^{2+}=\mathrm{Fe}^{2+}, \mathrm{Mn}^{2+}, \mathrm{Mg}^{2+}, \mathrm{Zn}^{2+}$ and 
$957 \mathrm{R}^{3+}=\mathrm{Fe}^{3+},{ }^{\mathrm{C}} \mathrm{Al}^{3+}$. The endmember compositions of katophorite (sodic-calcic), arfvedsonite and 958 leakeite (sodic) are indicated on the diagrams. In the legend "fgr" (southern hypersolvus granite) 959 refers to the fine-grained rocks of the unit, whereas "peg" stands for the oikiocrystic to 960 pegmatitic textured rocks.

961 Fig. 5: Binary diagrams showing major and minor element concentrations of amphibole in atoms 962 per formula unit (apfu), all as a function of $\mathrm{Al}$ concentration (X-axis). The decreasing $\mathrm{Al}$ content 963 monitors the differentiation of the magma.

964 Fig. 6: Binary diagrams showing the changing concentration (apfu) of selected elements as a 965 function of $\mathrm{Al}$ concentration (dashed arrows) from the cores to rims of amphibole phenocrysts in 966 the transsolvus granite.

967 Fig. 7: Chondrite-normalized REE- and trace element profiles of the Strange Lake amphibole968 group minerals displayed with the average bulk rock profiles of the respective units. a) REE- and b) trace element spider diagram for the southern hypersolvus granite; c) REE- and d) trace 970 element spider diagram for the northern hypersolvus granite; and e) REE- and f) trace element 971 spider diagram for the transsolvus granite and enclaves. The chondrite values are from Sun and 972 McDonough, 1989. Fig. 8: Chondrite-normalized REE-spider diagrams showing the average distribution of the 974 elements corresponding to the amphibole species identified in the Strange Lake pluton. The 975 chondrite values are from Sun and McDonough, 1989.

976 Fig. 9: Binary diagram showing the amphibole $\mathrm{Fe}^{2+} / \mathrm{Fe}^{3+}$ ratio as a function of the $\mathrm{Na} / \mathrm{Ca}$ ratio in 977 both, hypersolvus and transsolvus granite indicating a (low degree) coupled behavior of the 978 ratios in rocks with the same major phase paragenesis. 
Fig. 10: Bar diagram showing the (average) relative proportion of the anions occupying the Wsite for each granite unit.

Fig. 11: Binary diagram illustrating the positive correlation between $\mathrm{Fe}^{3+}$ and $\mathrm{Li}^{+}$in amphibole from the different granite facies. Linear trend lines and correlation coefficients have been added to distinguish amphibole in the hypersolvus granite from that in the transsolvus granite. Lithium concentrations are consistently lower in the hypersolvus granite than in the transsolvus granite.

Fig. 12: Binary diagrams showing the total REE concentration in amphibole of the different granite facies as a function of the concentration of selected major elements. Also shown are the corresponding trend lines and correlation coefficients $\left(\mathrm{R}^{2}\right)$.

Fig. 13: Diagram showing the ionic radii of the REE either in 6-fold (C-site) or 8-fold (B-site) coordination versus the apparent partition coefficient $\mathrm{D}_{\text {arf-bulk }}$ (median REE content of amphibole / REE content of the bulk rock, sample 204720), plotted with error bars (median absolute deviation). Also shown is a Lattice-Strain Theory fit through these data (solid line).

Fig. 14: Chart comparing the relative proportions of the bulk rock REE concentrations hosted by amphibole (average values) for each granite facies (see text for details). The chart for the southern hypersolvus granite only considers fine-grained samples.

Fig. 15: Cartoons showing the evolution of amphibole in the context of the textural development of a) hypersolvus and b) transsolvus granite, from liquidus to solidus stages and the subsolidus Na-alteration that affected the transsolvus granite. Crystallization temperature-, pressure- and oxygen fugacity ranges are given, and were taken from the studies of the Strange Lake pluton by Salvi and Williams-Jones (1992) and Vasyukova et al. (2016). The $f \mathrm{O}_{2}$ ranges are indicated in 
1000 respect to the iron oxide buffers, $\mathrm{MH}$ (magnetite-hematite), QFM (quartz-fayalite-magnetite) and 1001 QIF (quartz-iron-fayalite). 


\section{Tables}

1003 Table 1: Average (median) bulk rock major and trace element compositions of the unaltered

1004 granites from the center of the Strange Lake pluton $\left(*\right.$ fgr $=$ fine grained samples, ${ }^{+}$oik/peg $=$ 1005 oikocrystic and pegmatitic samples)

\begin{tabular}{|c|c|c|c|c|c|c|c|c|c|c|}
\hline \multirow{3}{*}{$\begin{array}{l}\text { Unit } \\
\text { Samples }\end{array}$} & \multicolumn{2}{|c|}{$\begin{array}{l}\text { Hypersolvus } \\
\text { granite S fgr* }\end{array}$} & \multicolumn{2}{|c|}{$\begin{array}{l}\text { Hypersolvus } \\
\text { granite S oik/peg }\end{array}$} & \multicolumn{2}{|c|}{$\begin{array}{l}\text { Hypersolvus } \\
\text { granite } \mathrm{N}\end{array}$} & \multicolumn{2}{|c|}{$\begin{array}{l}\text { Transsolvus } \\
\text { granite }\end{array}$} & \multicolumn{2}{|c|}{ Enclaves } \\
\hline & 7 & & 8 & & 12 & & 24 & & 12 & \\
\hline & & $+/-$ & & $+/-$ & & $+/-$ & & $+/-$ & & $+/-$ \\
\hline $\mathrm{SiO}_{2}$ wt. $\%$ & 69.04 & 0.89 & 70.57 & 0.56 & 70.68 & 0.36 & 71.28 & 0.53 & 69.36 & 0.60 \\
\hline $\mathrm{Al}_{2} \mathrm{O}_{3}$ & 11.88 & 0.26 & 10.57 & 0.17 & 11.74 & 0.21 & 10.27 & 0.39 & 11.97 & 0.25 \\
\hline $\mathrm{Fe}_{2} \mathrm{O}_{3}$ & 5.78 & 0.31 & 6.72 & 0.52 & 4.89 & 0.08 & 5.98 & 0.47 & 5.05 & 0.10 \\
\hline $\mathrm{MnO}$ & 0.10 & 0.01 & 0.11 & 0.01 & 0.10 & 0.01 & 0.12 & 0.01 & 0.09 & 0.02 \\
\hline $\mathrm{MgO}$ & 0.04 & 0.01 & 0.02 & 0.01 & 0.05 & 0.01 & 0.03 & 0.01 & 0.04 & 0.02 \\
\hline $\mathrm{CaO}$ & 0.73 & 0.19 & 0.37 & 0.11 & 0.57 & 0.03 & 0.45 & 0.18 & 0.83 & 0.15 \\
\hline $\mathrm{Na}_{2} \mathrm{O}$ & 4.92 & 0.17 & 5.11 & 0.05 & 5.09 & 0.10 & 5.08 & 0.35 & 3.60 & 0.98 \\
\hline $\mathrm{K}_{2} \mathrm{O}$ & 4.93 & 0.21 & 4.48 & 0.09 & 4.74 & 0.11 & 4.32 & 0.31 & 7.60 & 1.61 \\
\hline $\mathrm{TiO}_{2}$ & 0.28 & 0.03 & 0.21 & 0.03 & 0.27 & 0.01 & 0.21 & 0.05 & 0.15 & 0.04 \\
\hline $\mathrm{Nb}_{2} \mathrm{O}_{5}$ & 0.03 & 0.01 & 0.05 & 0.01 & 0.06 & 0.005 & 0.05 & 0.02 & 0.02 & 0.02 \\
\hline $\mathrm{P}_{2} \mathrm{O}_{5}$ & 0.02 & 0.00 & 0.02 & - & 0.02 & 0.01 & 0.01 & 0.01 & - & - \\
\hline $\mathrm{F}$ & 0.44 & 0.02 & 0.37 & 0.09 & 0.46 & 0.04 & 0.51 & 0.06 & 0.49 & 0.07 \\
\hline TREO & 0.17 & 0.03 & 0.19 & 0.02 & 0.24 & 0.03 & 0.48 & 0.06 & 0.25 & 0.03 \\
\hline LREO & 0.12 & 0.02 & 0.13 & 0.02 & 0.16 & 0.02 & 0.33 & 0.04 & 0.16 & 0.02 \\
\hline HREO+Y & 0.05 & 0.005 & 0.06 & 0.01 & 0.08 & 0.01 & 0.11 & 0.04 & 0.09 & 0.01 \\
\hline LOI & 0.72 & & 0.47 & & 0.70 & & 0.72 & & 0.83 & \\
\hline Total & 98.53 & & 99.19 & & 99.14 & & 99.20 & & 99.68 & \\
\hline Agp index & 1.13 & 0.02 & 1.23 & 0.02 & 1.15 & 0.03 & 1.27 & 0.03 & 1.17 & 0.02 \\
\hline $\mathrm{Be}(p p m)$ & 36 & 8 & 40 & 14 & 53 & 11 & 54 & 22 & 31 & 7 \\
\hline $\mathrm{Zn}$ & 285 & 40 & 545 & 30 & 465 & 60 & 585 & 90 & 465 & 145 \\
\hline $\mathrm{Ga}$ & 45 & 3 & 52 & 3 & 44 & 1 & 60 & 3 & 48 & 5 \\
\hline $\mathrm{Rb}$ & 417 & 23 & 436 & 31 & 522 & 47 & 672 & 99 & 925 & 241 \\
\hline $\mathrm{Sr}$ & 18 & 5 & 15 & 5 & 21 & 7 & 21 & 8 & 21 & 5 \\
\hline $\mathrm{Y}$ & 266 & 17 & 293 & 36 & 392 & 74 & 616 & 196 & 556 & 48 \\
\hline $\mathrm{Zr}$ & 2413 & 667 & 2504 & 469 & 3656 & 268 & 4984 & 1917 & 1488 & 1126 \\
\hline $\mathrm{Ba}$ & 76 & 13 & 43 & 8 & 85 & 18 & 43 & 15 & 58 & 14 \\
\hline $\mathrm{La}$ & 228 & 33 & 221 & 35 & 305 & 51 & 630 & 81 & 286 & 47 \\
\hline $\mathrm{Ce}$ & 464 & 73 & 485 & 72 & 629 & 79 & 1235 & 170 & 589 & 88 \\
\hline $\mathrm{Pr}$ & 56 & 14 & 60 & 7 & 73 & 10 & 149 & 20 & 74 & 10 \\
\hline $\mathrm{Nd}$ & 191 & 42 & 207 & 27 & 240 & 35 & 527 & 52 & 282 & 23 \\
\hline $\mathrm{Sm}$ & 39 & 10 & 51 & 6 & 49 & 6 & 115 & 16 & 68 & 5 \\
\hline $\mathrm{Eu}$ & 2 & 0.4 & 3 & 0.4 & 3 & 0.4 & 6 & 1 & 4 & 0.2 \\
\hline $\mathrm{Gd}$ & 33 & 5 & 44 & 7 & 45 & 7 & 100 & 18 & 66 & 7 \\
\hline $\mathrm{Tb}$ & 6 & 1 & 8 & 1 & 10 & 1 & 17 & 4 & 12 & 1 \\
\hline Dy & 44 & 7 & 53 & 8 & 69 & 12 & 103 & 29 & 72 & 10 \\
\hline Ho & 10 & 2 & 11 & 2 & 15 & 2 & 21 & 7 & 14 & 3 \\
\hline $\mathrm{Er}$ & 33 & 6 & 36 & 7 & 50 & 6 & 64 & 24 & 37 & 10 \\
\hline $\mathrm{Tm}$ & 5 & 1 & 6 & 1 & 8 & 1 & 9 & 4 & 5 & 2 \\
\hline $\mathrm{Yb}$ & 36 & 3 & 42 & 9 & 57 & 4 & 58 & 29 & 25 & 10 \\
\hline $\mathrm{Lu}$ & 6 & 0.4 & 7 & 1 & 9 & 1 & 8 & 4 & 4 & 1 \\
\hline
\end{tabular}




\begin{tabular}{lcccccccccc}
$\mathrm{Hf}$ & 69 & 12 & 67 & 12 & 97 & 15 & 136 & 47 & 42 & 31 \\
$\mathrm{Ta}$ & 14 & 1 & 20 & 4 & 28 & 4 & 25 & 13 & 7 & 5 \\
$\mathrm{~Pb}$ & 94 & 17 & 169 & 53 & 137 & 38 & 187 & 73 & 38 & 21 \\
$\mathrm{Th}$ & 54 & 9 & 69 & 20 & 88 & 15 & 84 & 40 & 23 & 17 \\
$\mathrm{U}$ & 10 & 3 & 14 & 3 & 19 & 2 & 17 & 8 & 4 & 3 \\
\hline
\end{tabular}

1006

Siegel K, Williams-Jones AE, van Hinsberg VJ (2017) The amphiboles of the REE-rich A-type peralkaline Strange Lake pluton fingerprints of magma evolution. Lithos 288:156-174. doi: 10.1016/j.lithos.2017.07.012. 
1007 Table 2: Average calculated formulae and cation assignments (in apfu) of amphibole group 1008 minerals, based on 24 oxygens. Ideal site occupation is noted in brackets. The rock units are: HS $1009 \mathrm{~S}$ fgr (hypersolvus granite south, fine grained), HS N (hypersolvus granite north), EN (enclaves), 1010 TS (transsolvus granite).

\begin{tabular}{|c|c|c|c|c|c|}
\hline Species & $\begin{array}{c}\text { Arfved } \\
\text { sonite }\end{array}$ & $\begin{array}{l}\text { Fluor- } \\
\text { arfveds } \\
\text { onite }\end{array}$ & $\begin{array}{l}\text { Ferro- } \\
\text { ferri- } \\
\text { leakeite }\end{array}$ & $\begin{array}{l}\text { Ferro- } \\
\text { ferri- } \\
\text { fluoro- } \\
\text { leakeite }\end{array}$ & $\begin{array}{c}\text { Ferro- } \\
\text { ferri- } \\
\text { kato- } \\
\text { phorite }\end{array}$ \\
\hline Unit & HS S & $\begin{array}{c}\text { all } \\
\text { units }\end{array}$ & & $\begin{array}{c}\text { HS N, } \\
\text { TS }\end{array}$ & $\begin{array}{c}\text { HS S } \\
\text { fgr }\end{array}$ \\
\hline Analyses & $n=12$ & $n=56$ & $n=5$ & $n=70$ & $n=6$ \\
\hline \multicolumn{6}{|c|}{ Formula Assignments } \\
\hline $\mathrm{Si}$ & 7.64 & 7.83 & 7.64 & 7.74 & 7.53 \\
\hline $\mathrm{Al}$ & 0.23 & 0.10 & 0.11 & 0.07 & 0.36 \\
\hline $\mathrm{Ti}$ & 0.09 & 0.09 & 0.11 & 0.09 & 0.11 \\
\hline $\mathrm{Fe}^{3+}$ & 0.10 & 0.03 & 0.15 & 0.12 & 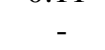 \\
\hline $\mathrm{T}(8)$ & 8.00 & 8.00 & 8.00 & 8.00 & 8.00 \\
\hline $\mathrm{Ti}$ & 0.09 & 0.06 & - & 0.03 & 0.10 \\
\hline $\mathrm{Zr}$ & 0.01 & 0.01 & 0.02 & 0.01 & - \\
\hline $\mathrm{Al}$ & 0.10 & 0.05 & - & - & - \\
\hline REE & 0.02 & 0.01 & 0.01 & - & 0.03 \\
\hline $\mathrm{Fe}^{3+}$ & 1.66 & 1.70 & 1.99 & 2.01 & 1.36 \\
\hline $\mathrm{Zn}$ & 0.08 & 0.04 & 0.11 & 0.05 & 0.06 \\
\hline $\mathrm{Mn}^{2+}$ & 0.09 & 0.10 & 0.09 & 0.08 & 0.10 \\
\hline $\mathrm{Fe}^{2+}$ & 2.62 & 2.49 & 1.96 & 2.00 & 3.02 \\
\hline $\mathrm{Mg}$ & 0.06 & 0.04 & 0.05 & 0.02 & 0.09 \\
\hline $\mathrm{Li}$ & 0.29 & 0.31 & 0.71 & 0.74 & 0.15 \\
\hline $\mathrm{C}(5)$ & 4.87 & 4.75 & 4.94 & 4.92 & 4.91 \\
\hline $\mathrm{Li}$ & - & - & 0.07 & 0.08 & - \\
\hline $\mathrm{Ca}$ & 0.23 & 0.10 & 0.09 & 0.03 & 0.57 \\
\hline $\mathrm{Na}$ & 1.77 & 1.90 & 1.87 & 1.95 & 1.43 \\
\hline B (2) & 2.00 & 2.00 & 2.00 & 2.00 & 2.00 \\
\hline $\mathrm{Na}$ & 0.79 & 0.89 & 0.87 & 0.86 & 0.69 \\
\hline K & 0.28 & 0.31 & 0.31 & 0.33 & 0.26 \\
\hline $\mathrm{A}(0-1)$ & 1.07 & 1.20 & 1.18 & 1.19 & 0.95 \\
\hline $\mathrm{OH}$ & 1.05 & 0.70 & 0.93 & 0.61 & 1.14 \\
\hline F & 0.72 & 1.07 & 0.85 & 1.20 & 0.44 \\
\hline $\mathrm{Cl}$ & 0.01 & - & - & - & 0.01 \\
\hline $\mathrm{O}$ & 0.23 & 0.22 & 0.21 & 0.19 & 0.41 \\
\hline W (2) & 2.00 & 2.00 & 2.00 & 2.00 & 2.00 \\
\hline
\end{tabular}

1011 
1012 Table 3: List of amphibole and titanium bearing minerals identified in the unaltered Strange Lake

1013 granites with their endmember structural formulae

\begin{tabular}{ll}
\hline Mineral name & Formula \\
\hline $\begin{array}{l}\text { Amphibole-group minerals } \\
\text { (Fluoro)-arfvedsonite }\end{array}$ & \\
$\begin{array}{l}\text { Ferro-ferri-(fluoro)-katophorite } \\
\text { Ferro-ferri-(fluoro)-leakeite }\end{array}$ & $\mathrm{NaNa}_{2}\left(\mathrm{Fe}^{2+}{ }_{4} \mathrm{Fe}^{3+}\right) \mathrm{Si}_{8} \mathrm{O}_{22}(\mathrm{OH}, \mathrm{F})_{2}$ \\
& $\mathrm{NaNa}_{2}\left(\mathrm{Fe}^{2+}\right)_{2}\left(\mathrm{Fe}^{3+}\right)_{2} \mathrm{LiSi}_{8} \mathrm{~S}_{22}(\mathrm{OH}, \mathrm{F})_{2}$ \\
Clinopyroxenes & \\
Aegirine & \\
& $\mathrm{NaFe}^{3+} \mathrm{Si}_{2} \mathrm{O}_{6}$ \\
Titano-silicates and Ti-oxide mineral \\
$\begin{array}{l}\text { Aenigmatite } \\
\text { Astrophyllite }\end{array}$ \\
$\begin{array}{l}\text { Narsarsukite } \\
\text { Titanite }\end{array}$ \\
$\begin{array}{l}\mathrm{Na}_{2} \mathrm{Fe}^{2+}{ }_{5} \mathrm{TiSi}_{6} \mathrm{O}_{20} \\
\text { Ilmenite }\end{array}$ & $\left(\mathrm{K}_{2} \mathrm{Na}_{3}\left(\mathrm{Fe}^{2+}\right)_{7} \mathrm{Ti}_{2} \mathrm{Si}_{8} \mathrm{O}_{26}(\mathrm{OH})_{4}\right.$ \\
\hline
\end{tabular}

1014 
1015 Table 4: Average (median) major and trace element compositions with median absolute 1016 deviation (+/-) of the amphibole group minerals from the unaltered part of the Strange Lake 1017 pluton $\left(* \mathrm{fgr}=\right.$ fine grained samples, ${ }^{+}$oik/peg $=$oikocrystic and pegmatitic samples $)$

\begin{tabular}{|c|c|c|c|c|c|c|c|c|c|c|}
\hline \multirow{2}{*}{$\begin{array}{l}\text { Unit } \\
\text { Analyses }\end{array}$} & \multicolumn{2}{|c|}{$\begin{array}{l}\text { Hypersolvus } \\
\text { granite S fgr* }\end{array}$} & \multicolumn{2}{|c|}{$\begin{array}{l}\text { Hypersolvus } \\
\text { granite S oik/peg }\end{array}$} & \multicolumn{2}{|c|}{$\begin{array}{l}\text { Hypersolvus } \\
\text { granite N }\end{array}$} & \multicolumn{2}{|l|}{ Enclaves } & \multicolumn{2}{|c|}{$\begin{array}{l}\text { Transsolvus } \\
\text { granite }\end{array}$} \\
\hline & $n=13$ & & $n=19$ & & $n=39$ & & $n=9$ & & $n=72$ & \\
\hline & & $+/-$ & & $+/-$ & & $+/-$ & & $+/-$ & & $+/-$ \\
\hline $\mathrm{SiO}_{2}$ wt. $\%$ & 48.29 & 0.51 & 49.97 & 0.80 & 50.71 & 0.19 & 50.71 & 0.93 & 51.02 & 0.52 \\
\hline $\mathrm{Al}_{2} \mathrm{O}_{3}$ & 1.47 & 0.30 & 0.99 & 0.15 & 0.50 & 0.08 & 0.36 & 0.01 & 0.34 & 0.05 \\
\hline $\mathrm{TiO}_{2}$ & 1.45 & 0.30 & 0.84 & 0.12 & 1.09 & 0.14 & 0.92 & 0.08 & 0.71 & 0.09 \\
\hline $\mathrm{FeO}$ & 33.67 & 0.42 & 33.80 & 0.41 & 32.06 & 0.27 & 31.78 & 0.22 & 32.47 & 0.38 \\
\hline $\mathrm{MgO}$ & 0.72 & 0.05 & 0.64 & 0.05 & 0.85 & 0.03 & 0.71 & 0.08 & 0.56 & 0.04 \\
\hline $\mathrm{MnO}$ & 0.34 & 0.07 & 0.10 & 0.08 & 0.22 & 0.03 & 0.09 & 0.03 & 0.08 & 0.03 \\
\hline $\mathrm{ZnO}$ & 0.62 & 0.16 & 0.24 & 0.05 & 0.45 & 0.04 & 0.60 & 0.11 & 0.30 & 0.05 \\
\hline $\mathrm{ZrO}_{2}$ & 0.04 & 0.02 & 0.06 & 0.03 & 0.17 & 0.04 & 0.13 & 0.03 & 0.11 & 0.03 \\
\hline $\mathrm{Nb}_{2} \mathrm{O}_{5}$ & 0.07 & 0.02 & 0.02 & 0.01 & 0.02 & 0.02 & 0.02 & 0.01 & 0.01 & 0.004 \\
\hline $\mathrm{Na}_{2} \mathrm{O}$ & 7.25 & 0.54 & 9.18 & 0.20 & 9.36 & 0.09 & 9.34 & 0.19 & 9.57 & 0.13 \\
\hline $\mathrm{K}_{2} \mathrm{O}$ & 1.27 & 0.15 & 1.28 & 0.12 & 1.59 & 0.11 & 1.73 & 0.09 & 1.65 & 0.09 \\
\hline $\mathrm{CaO}$ & 2.79 & 0.69 & 1.11 & 0.50 & 0.47 & 0.08 & 0.13 & 0.05 & 0.13 & 0.03 \\
\hline $\mathrm{F}$ & 1.29 & 0.31 & 1.97 & 0.27 & 2.08 & 0.12 & 2.05 & 0.18 & 2.56 & 0.15 \\
\hline $\mathrm{Cl}$ & 0.03 & 0.01 & 0.02 & 0.01 & 0.01 & 0.01 & - & - & 0.01 & 0.005 \\
\hline Total & 99.18 & & 100.5 & & 99.87 & & 98.84 & & 99.93 & \\
\hline $\mathrm{Li}(p p m)$ & 1613 & 772 & 1450 & 615 & 3099 & 549 & 4802 & 931 & 5775 & 1260 \\
\hline $\mathrm{Rb}$ & 58.8 & 17.8 & 20.9 & 6.3 & 61.8 & 9.4 & 88.7 & 15.5 & 84.3 & 18.6 \\
\hline $\mathrm{Sr}$ & 23.3 & 6.8 & 8.5 & 3.0 & 11.7 & 3.7 & 4.0 & 1.4 & 1.4 & 0.5 \\
\hline $\mathrm{Y}$ & 471 & 145 & 70.9 & 26.0 & 107 & 27 & 92.0 & 32.0 & 27.7 & 5.5 \\
\hline $\mathrm{Zr}$ & 1208 & 653 & 647 & 124 & 2648 & 450 & 2073 & 234 & 1356 & 339 \\
\hline $\mathrm{Sn}$ & 160 & 80.3 & 21.3 & 8.9 & 156 & 49 & 90.1 & 36.2 & 137 & 41 \\
\hline $\mathrm{La}$ & 96.0 & 11.2 & 31.9 & 9.5 & 32.4 & 5.9 & 24.1 & 8.5 & 2.8 & 1.2 \\
\hline $\mathrm{Ce}$ & 282 & 24 & 91.6 & 14.7 & 85.9 & 22.6 & 45.3 & 9.7 & 6.6 & 2.8 \\
\hline $\operatorname{Pr}$ & 44.4 & 4.9 & 13.5 & 2.8 & 13.7 & 4.3 & 6.9 & 1.6 & 1.0 & 0.4 \\
\hline $\mathrm{Nd}$ & 218 & 25 & 60.1 & 15.7 & 62.3 & 20.5 & 32.5 & 8.0 & 4.7 & 2.2 \\
\hline $\mathrm{Sm}$ & 59.7 & 7.3 & 13.8 & 2.7 & 11.6 & 4.5 & 6.2 & 1.3 & 0.91 & 0.47 \\
\hline $\mathrm{Eu}$ & 4.0 & 0.3 & 0.85 & 0.22 & 0.68 & 0.30 & 0.37 & 0.17 & 0.05 & 0.02 \\
\hline Gd & 50.0 & 5.8 & 9.6 & 2.0 & 7.6 & 3.1 & 9.3 & 3.9 & 0.67 & 0.33 \\
\hline $\mathrm{Tb}$ & 10.6 & 1.5 & 1.7 & 0.5 & 1.6 & 0.6 & 1.7 & 0.7 & 0.21 & 0.08 \\
\hline Dy & 71.7 & 13.8 & 12.4 & 2.3 & 18.3 & 5.7 & 11.4 & 3.0 & 2.6 & 0.6 \\
\hline Ho & 17.1 & 3.7 & 3.1 & 0.5 & 7.7 & 1.8 & 3.2 & 0.9 & 1.2 & 0.3 \\
\hline $\mathrm{Er}$ & 69.7 & 21.2 & 15.1 & 2.9 & 48.5 & 12.3 & 14.9 & 1.2 & 8.1 & 1.4 \\
\hline $\mathrm{Tm}$ & 14.2 & 4.4 & 4.3 & 1.0 & 17.5 & 4.8 & 4.6 & 0.8 & 2.7 & 0.5 \\
\hline $\mathrm{Yb}$ & 144 & 52 & 53.1 & 11.8 & 215 & 53 & 52.4 & 5.7 & 35.9 & 6.3 \\
\hline $\mathrm{Lu}$ & 29.5 & 11.6 & 11.7 & 2.6 & 50.1 & 11.5 & 12.8 & 3.1 & 8.6 & 1.9 \\
\hline $\mathrm{Hf}$ & 60.3 & 35.8 & 27.5 & 7.0 & 130 & 25 & 85.0 & 20.6 & 63.6 & 17.6 \\
\hline $\mathrm{Ta}$ & 9.0 & 1.7 & 2.2 & 0.4 & 2.9 & 0.8 & 1.9 & 0.6 & 1.1 & 0.3 \\
\hline $\mathrm{Pb}$ & 77.9 & 8.0 & 8.9 & 5.1 & 34.5 & 10.5 & 10.7 & 4.6 & 5.8 & 1.7 \\
\hline $\mathrm{Nb}$ & 468 & 116 & 124 & 51 & 214 & 34 & 109 & 20 & 92.4 & 13.8 \\
\hline $\mathrm{Ba}$ & 10.5 & 6.3 & 3.4 & 2.5 & 6.0 & 2.4 & 1.9 & 0.9 & 0.43 & 0.26 \\
\hline Th & 1.7 & 1.4 & 0.75 & 0.66 & 0.51 & 0.47 & 2.9 & 2.5 & 0.02 & 0.02 \\
\hline U & 0.13 & 0.10 & 0.13 & 0.11 & 0.03 & 0.03 & 0.16 & 0.15 & 0.01 & 0.01 \\
\hline
\end{tabular}




\begin{tabular}{lllllllllll}
\hline TREE+Y & 1634 & 297 & 395 & 91 & 708 & 174 & 389 & 117 & 110 & 19
\end{tabular}

Siegel K, Williams-Jones AE, van Hinsberg VJ (2017) The amphiboles of the REE-rich A-type peralkaline Strange Lake pluton fingerprints of magma evolution. Lithos 288:156-174. doi: 10.1016/j.lithos.2017.07.012. 
1019 Table 5: Average (median) core and rim compositions (in apfu) with median absolute deviation

1020 (+/-) of selected phenocrysts from the transsolvus granite

\begin{tabular}{|c|c|c|c|c|}
\hline \multirow{2}{*}{$\begin{array}{l}\text { Location } \\
\text { Analyses }\end{array}$} & \multirow{2}{*}{$\begin{array}{l}\text { Core } \\
n=24\end{array}$} & \multicolumn{3}{|c|}{ Rim } \\
\hline & & & $n=7$ & \\
\hline & & $+/-$ & & $+/-$ \\
\hline${ }^{\mathrm{T}} \mathrm{Si}(a p f u)$ & 7.906 & 0.102 & 7.716 & 0.039 \\
\hline${ }^{\mathrm{T}} \mathrm{Al}$ & 0.059 & 0.006 & 0.059 & 0.003 \\
\hline${ }^{\mathrm{T}} \mathrm{Ti}$ & 0.072 & 0.010 & 0.083 & 0.008 \\
\hline${ }^{\mathrm{T}} \mathrm{Fe}^{3+}$ & 0.143 & 0.030 & 0.135 & 0.025 \\
\hline${ }^{\mathrm{C}} \mathrm{Ti}$ & 0.084 & 0.016 & 0.001 & - \\
\hline${ }^{\mathrm{C}} \mathrm{Zr}$ & 0.008 & 0.003 & 0.008 & 0.002 \\
\hline${ }^{\mathrm{C}} \mathrm{Al}$ & 0.052 & 0.019 & - & - \\
\hline${ }^{\mathrm{C}} \mathrm{REE}$ & 0.002 & 0.001 & 0.002 & - \\
\hline${ }^{\mathrm{C}} \mathrm{Fe}^{3+}$ & 1.763 & 0.215 & 2.022 & 0.007 \\
\hline${ }^{\mathrm{C}} \mathrm{Zn}$ & 0.034 & 0.006 & 0.072 & 0.015 \\
\hline${ }^{\mathrm{C}} \mathrm{Mn}^{2+}$ & 0.072 & 0.004 & 0.081 & 0.007 \\
\hline${ }^{\mathrm{C}} \mathrm{Fe}^{2+}$ & 2.441 & 0.321 & 1.952 & 0.058 \\
\hline${ }^{\mathrm{C}} \mathrm{Mg}$ & 0.026 & 0.006 & 0.014 & 0.001 \\
\hline $\mathrm{C}_{\mathrm{Li}}{ }^{\circ}$ & 0.407 & 0.232 & 0.825 & 0.044 \\
\hline${ }^{\mathrm{B}} \mathrm{Li}$ & 0.051 & 0.024 & 0.066 & 0.024 \\
\hline${ }^{\mathrm{B}} \mathrm{Ca}$ & 0.024 & 0.006 & 0.019 & 0.005 \\
\hline${ }^{\mathrm{B}} \mathrm{Na}$ & 1.973 & 0.009 & 1.964 & 0.017 \\
\hline${ }^{\mathrm{A}} \mathrm{Na}$ & 0.867 & 0.042 & 0.838 & 0.037 \\
\hline${ }^{\mathrm{A}} \mathrm{K}$ & 0.317 & 0.011 & 0.347 & 0.050 \\
\hline${ }^{\mathrm{w}} \mathrm{F}$ & 1.205 & 0.057 & 1.027 & 0.122 \\
\hline total $\mathrm{Ti}$ & 0.156 & 0.026 & 0.083 & 0.008 \\
\hline total $\mathrm{Al}$ & 0.111 & 0.025 & 0.059 & 0.003 \\
\hline total $\mathrm{Fe}^{3+}$ & 0.074 & 0.011 & 2.164 & 0.046 \\
\hline total $\mathrm{Na}$ & 1.906 & 0.245 & 2.769 & 0.040 \\
\hline total $\mathrm{Li}$ & 8.034 & 0.006 & 0.860 & 0.071 \\
\hline total $\mathrm{Fe}$ & 0.156 & 0.020 & 0.825 & 0.044 \\
\hline $\mathrm{Fe}^{2+} / \mathrm{Fe}^{3+}$ & 2.449 & 0.324 & 2.134 & 0.040 \\
\hline
\end{tabular}

1021 
1022 Table 6: Apparent melt-arfvedsonite partition coefficients ( $\left.\mathrm{D}_{\text {arf-bulk}}\right)$, ionic radius ' $\mathrm{r}$ ' in 6- and 8-

1023 fold coordination, ideal radius (r) for each element and median absolute deviation (MAD)

\begin{tabular}{lccccc}
\hline & $\mathrm{D}_{\text {arf-bulk }}$ & $\mathrm{r}_{\text {6-fold }}$ & $\mathrm{r}_{\text {8-fold }}$ & $\mathrm{r}$ & $\mathrm{MAD}^{*}$ \\
\hline $\mathrm{La}$ & 0.006 & 1.03 & 1.16 & 1.2 & 0.005 \\
$\mathrm{Ce}$ & 0.005 & 1.01 & 1.14 & 1.1 & 0.003 \\
$\mathrm{Pr}$ & 0.005 & 0.99 & 1.13 & 1.1 & 0.003 \\
$\mathrm{Nd}$ & 0.008 & 0.98 & 1.11 & 1.1 & 0.004 \\
$\mathrm{Sm}$ & 0.006 & 0.96 & 1.08 & 1.1 & 0.002 \\
$\mathrm{Eu}$ & 0.006 & 0.95 & 1.07 & 1.1 & 0.004 \\
$\mathrm{Gd}$ & 0.006 & 0.94 & 1.05 & 0.9 & 0.003 \\
$\mathrm{~Tb}$ & 0.014 & 0.92 & 1.04 & 0.9 & 0.002 \\
$\mathrm{Dy}$ & 0.027 & 0.91 & 1.03 & 0.9 & 0.005 \\
$\mathrm{Ho}$ & 0.075 & 0.90 & 1.02 & 0.9 & 0.011 \\
$\mathrm{Er}$ & 0.201 & 0.89 & 1.00 & 0.9 & 0.016 \\
$\mathrm{Tm}$ & 0.657 & 0.88 & 0.99 & 0.9 & 0.053 \\
$\mathrm{Yb}$ & 1.664 & 0.87 & 0.99 & 0.9 & 0.165 \\
$\mathrm{Lu}$ & 3.261 & 0.86 & 0.98 & 0.9 & 0.321 \\
$\mathrm{Y}$ & 0.043 & 0.90 & 1.02 & 0.9 & 0.006 \\
\hline
\end{tabular}

1024

1025 "The Median Absolute Deviation (MAD) is reported (plotted as error bars in Fig. 14) instead of the standard deviation, as the 1026 median amphibole concentration was used instead of the mean concentration. 
1028 Appendix A: Standards, counting time and detection limits used for electron microprobe 1029 analyses (EMPA) of the amphibole group minerals

\begin{tabular}{llcc}
\hline Element & Standard & $\begin{array}{c}\text { Counting } \\
\text { time (s) }\end{array}$ & $\begin{array}{c}\text { Detection } \\
\text { limit (ppm) }\end{array}$ \\
\hline $\mathrm{Na}$ & Albite & 20 & 267 \\
$\mathrm{Fe}$ & Hematite & 20 & 264 \\
$\mathrm{Mn}$ & Spessartine & 20 & 413 \\
$\mathrm{Ti}$ & Rutile & 20 & 370 \\
$\mathrm{Zr}$ & Zircon & 20 & 653 \\
$\mathrm{Si}$ & Diopside & 20 & 363 \\
$\mathrm{Ca}$ & Diopside & 20 & 243 \\
$\mathrm{Mg}$ & Diopside & 20 & 266 \\
$\mathrm{Al}$ & Orthoclase & 20 & 216 \\
$\mathrm{~K}$ & Orthoclase & 20 & 205 \\
$\mathrm{Cl}$ & Vanadinite & 20 & 218 \\
$\mathrm{~F}$ & Fluorite & 100 & 1501 \\
$\mathrm{Zn}$ & Willemite & 20 & 427 \\
\hline
\end{tabular}

1030

1031 Detection limits and standard deviations (2 $\boldsymbol{\sigma})$ represent average detection limits calculated from repeated analyses of standards 1032 during the analytical runs. 


\title{
THE AMPHIBOLES OF THE REE-RICH A-TYPE PERALKALINE STRANGE LAKE PLUTON - FINGERPRINTS OF MAGMA EVOLUTION
}

\author{
Lithos \\ Karin Siegel $^{1)}$, Anthony E. Williams-Jones ${ }^{1)}$, Vincent J. van Hinsberg ${ }^{1)}$ \\ Affiliation / address: \\ ${ }^{1)}$ Department of Earth and Planetary Sciences, McGill University, 3450 University St., FDA, \\ room 238, Montréal, QC H3A 0E8, Canada
}

Corresponding author:

K. Siegel, email: karin.siegel@mail.mcgill.ca, phone: +1 4389929644

Co-authors:

A.E. Williams-Jones, email: ae.williams-jones@mcgill.ca

V. van Hinsberg, email: vincent.vanhinsberg@mcgill.ca 


\section{INTRODUCTION}

2 Our understanding of the genesis of intra-plate rift-generated intrusions that produce A-type granites is still incomplete. In particular, the reasons for the extremely high REE-, F- and other HFSE-concentrations in many of these peralkaline rocks are poorly known. In addition to the need for a highly fertile magma source, magmatic evolution by fractional crystallization appears to play a critical role in the enrichment of these elements (e.g., Kovalenko et al., 1995; Mungall and Martin, 1996). The chemistry of a major mineral, such as amphibole, which adapts to its $P$ $T-X$ environment, and is capable of hosting most cation sizes and charges, can potentially record this and any other processes that might have operated in the magma chamber. As a phenocryst, the amphibole would record the conditions prior to intrusion, and as a late crystallizing phase,

11 the in-situ crystal fractionation processes.

The well-known ability of minerals of the amphibole super-group to accommodate a wide variety of elements with highly variable ionic radius and charge, including alkali elements, high field strength elements (HFSE) and the rare earth elements (REE), makes it an ideal monitor of magma evolution (Abdel-Rahman, 1994; Marks et al., 2004). In this study, we use the occurrence and composition of amphibole-group minerals in the Strange Lake pluton, QuébecLabrador, Canada, to trace the evolution of a peralkaline granitic magma that is unusually enriched in the $\mathrm{REE}, \mathrm{Zr}$ and $\mathrm{Nb}$. This magma was the source of a large REE/HFSE resource (indicated resources: 278 million tons grading 0.93 wt. $\% \mathrm{REE}_{2} \mathrm{O}_{3}, 0.18$ wt. $\% \mathrm{Nb}_{2} \mathrm{O}_{5}$ and 1.92 wt. \% $\mathrm{ZrO}_{2}$; Quest Rare Minerals Ltd., 2012) that is currently being considered for exploitation. In this study, the $\mathrm{Na}, \mathrm{Ca}, \mathrm{Li}, \mathrm{Fe}^{3+}$ and $\mathrm{REE}$ contents of the amphibole-group minerals are used to gain information on the composition of the magma and conditions prior to, during and after its emplacement. The results show that fractional crystallization of a perthitic alkali feldspar, gravity 
settling of REE-minerals and zircon as well as the exsolution of a LREE-rich fluoride melt played a major role in the evolution of the magma and in concentrating the ore elements. They also show that the amphibole-group minerals host a significant proportion of the REE, and were the principal carriers of the HREE in some parts of the pluton.

\section{BACKGROUND INFORMATION}

A number of studies have traced evolutionary trends in alkaline rock suites using the crystal chemistry of the dominant mafic minerals (Davidson, 1982; Marks et al., 2004). In peralkaline rocks, which are defined by a molar excess of alkalis in respect to aluminum, the mafic minerals are usually of a sodic nature, e.g., amphiboles, such as arfvedsonite and riebeckite, or pyroxenes such as aegirine. The amphiboles of alkaline complexes generally trend from calcic through sodic-calcic to sodic members with differentiation, reflecting the increasing alkalinity of the melt from which they crystallized (Giret et al., 1980; Piilonen et al., 2013). They also display significant variations in REE and HFSE concentrations with magmatic differentiation, as shown, for example, by Marks et al. (2004) for the Gardar alkaline province (SW-Greenland). Similar conclusions have been reached for amphibole phenocrysts in alkaline basalts from the Rhine graben valley, Germany (Mayer et al., 2014).

Lithium has proven to be a particularly important constituent of alkali amphiboles (Camara et al., 2010; Hawthorne et al., 1993). Owing to its incompatible character in common rock-forming minerals, its concentration in amphibole may reflect the degree of melt differentiation. This case has been made for lithium-bearing amphiboles from Hurricane Mountain, New Hampshire, where the amphiboles vary from early Li-rich leakeite to late $\mathrm{Li}$-poor riebeckite (Hawthorne et al., 1996). The progressive depletion in lithium in crystals growing into miarolitic cavities in 
granitic pegmatites is consistent with the idea that a highly evolved melt with a high Li content formed the earlier leakeite, and that progressive fluid exsolution resulted in the removal of lithium and the growth of Li-poor riebeckite.

The 1240 Ma Strange Lake pluton (Miller et al., 1997) is an extraordinary example of hyperREE-, $\mathrm{Zr}-$, and $\mathrm{Nb}$ - enrichment in a peralkaline granite, and is composed of a sequence of granitic intrusions, two earlier hypersolvus granites and a later transsolvus granite (this study).

The last of these intrusions is host to numerous NYF-type pegmatites with extremely high concentrations of REE, particularly the heavy REE (HREE), $\mathrm{Zr}$ and $\mathrm{Nb}$. Most of the previous studies of the pluton have focused on the hydrothermal alteration and the rare-metal mineralized pegmatites (Gysi et al., 2016; Gysi and Williams-Jones, 2013; Kerr and Rafuse, 2012; Salvi and Williams-Jones, 1990; 1992; 1996; 1997; 2006; Vasyukova et al., 2016). Several studies, however, have addressed its magmatic evolution. Boily and Williams-Jones (1994) proposed that the REE-enrichment was due to a combination of fractional crystallization, and the heterogeneous distribution of F-rich residual melts, in which the REE and HFSE were transported as fluoro-complexes. Vasyukova and Williams-Jones (2014; 2016) provided evidence for the early separation of a REE- and Y-rich immiscible fluoride melt from the silicate melt, which accumulated in the highly evolved residual melts that formed the mineralized pegmatites.

Previous studies of the mafic minerals of the Strange Lake pluton concluded that the amphiboles are enriched in $\mathrm{Li}$ and $\mathrm{Zn}$, are associated with Ti-silicates and crystallized under relatively low $\mathrm{fO}_{2}$ (Pillet et al., 1993; Roelofsen, 1997). Hawthorne et al. (2001) showed that Li is an essential component of the amphiboles and identified lithian arfvedsonite and lithian manganoan arfvedsonite. 


\section{GEOLOGIC SETTING}

The Strange Lake pluton is part of the Nain Plutonic AMCG suite, which comprises anorthosites, mangerites, charnockites and granites (Miller, 1996; Gower and Krogh, 2002). Rocks of the Nain suite were emplaced along the boundary between the Archean Nain province and the Archean to Early Paleoproterozoic Churchill province (Emslie et al., 1994), more recently referred to as the Core Zone (James and Dunning, 2000). The Nain Plutonic Suite covers an area of $\sim 19,000 \mathrm{~km}^{2}$, and was emplaced between 1460 and $1240 \mathrm{Ma}$, with the Strange Lake pluton (1240 $\pm 2 \mathrm{Ma})$ representing the youngest intrusive body (Gower and Krogh, 2002).

To the south and west, the Strange Lake pluton intrudes the Napeu Kainiut quartz monzonite, which is interpreted to represent a satellite body of the Mistastin batholith (Miller et al., 1997). The Napeu Kainiut intrusion, which is composed mainly of quartz, K-feldspar, plagioclase and biotite, also occurs within the Strange Lake pluton as xenoliths and large roof pendants. The Mistastin batholith consists of pyroxene- and fayalite-bearing Rapakivi-textured granites, which were cut by younger biotite-hornblende-bearing granites and minor syenitic intrusions, such as the Misery Lake syenite, which hosts abundant REE mineralization (Petrella et al., 2014). Dated at 1420 Ma (Emslie and Stirling, 1993), the Mistastin batholith represents one of the oldest members of the Nain Plutonic Suite. The other host rock to the Strange Lake pluton is an Archean to Paleoproterozoic gneiss complex belonging to the Core Zone (Churchill Province), comprising quartzofeldspathic augen-gneiss, banded biotite gneiss and minor garnet-bearing paragneiss and mafic gneiss.

\subsection{The Strange Lake Pluton}


The circular (in outcrop), $\sim 6 \mathrm{~km}$ in diameter, Strange Lake pluton is located on the border between Québec and Labrador, and consists of a sequence of alkaline granitic intrusive units (Fig. 1). The earliest phase of the pluton is a hypersolvus granite (Pillet et al., 1992), its formation at conditions above those for the alkali feldspar solvus (Tuttle and Bowen, 1958). The hypersolvus granite occurs in the center and southern part of the pluton, and has been subdivided into a northern and a southern unit, based on bulk rock and mineral compositional differences. The third major unit, formerly classified as subsolvus granite (Boily and Williams-Jones, 1994; Salvi and Williams-Jones, 1996; Gysi and Williams-Jones, 2013), is now classified as transsolvus granite, and contains perthite phenocrysts as well as separate albite and K-feldspar crystals in the groundmass. It occupies much of the pluton, and has been strongly affected by hydrothermal activity. A smaller, unaltered part of the transsolvus granite is exposed in the center of the pluton and provided the samples for this study. The transsolvus granite commonly contains dark grey, fine-grained ovoid enclaves and barren pegmatite pockets; the altered transsolvus granite is host to highly REE/HFSE-enriched pegmatites. A dark grey porphyritic microgranite with a fine-grained matrix occurs in contact with remnants of country rock within the pluton and is interpreted to represent quenched hypersolvus granite. The enclaves in the transsolvus granite, some of which are compositionally similar to the hypersolvus granite, are interpreted to represent fragments of this quenched material; the other fragments represent quenched transsolvus granite. The pluton is surrounded by a purple to dark red fluorite-hematite breccia, delineating a ring-fault that contains angular fragments of the host rocks.

\subsection{Hypersolvus granite}

The hypersolvus granite has been subdivided into an equigranular and fine-grained northern part and a variably textured fine- to coarse-grained southern part (this study). Locally, the southern 
113 hypersolvus granite is coarse-grained and displays poikilitic to pegmatitic textures, which are

114 also observed in drill core of the northern hypersolvus granite (not sampled). These poikilitic textured samples contain anhedral arfvedsonite oikocrysts enclosing smaller crystals of perthitic alkali feldspar, whereas the pegmatitic samples are coarse-grained and contain comb-textured arfvedsonite, quartz, K-feldspar and minor proportions of alkali zirconosilicate minerals. Both the northern and southern hypersolvus granite units are composed of perthitic feldspar, quartz, and sodic amphibole. Minor microcline and albite are present in the groundmass, either reflecting evolution of the magma to conditions in the two-feldspar stability field or subsolidus hydrothermal crystallization. A number of alkali feldspar crystals of the southern hypersolvus granite contain inclusions of fibrous astrophyllite. The quartz and sodic amphibole both occur interstitially to the perthite, and the amphibole appears to have crystallized later than the quartz (Fig. 2a). In most of the southern hypersolvus granite samples, the amphibole exhibits swapped margins with perthite (Fig. 2b). The amphibole contains numerous inclusions of fluorite and a Yrich fluorite-fluocerite solid solution, particularly in the cores of crystals (Fig. 3a). In addition to the silicates mentioned above, a variety of interstitial zirconosilicate minerals, e.g., vlasovite, elpidite, dalyite and catapleiite replaced primary zircon (remnants of zircon in crystal cores). Titanosilicates occur mostly in the northern hypersolvus granite, and locally replaced the sodic amphibole. These minerals comprise dark red aenigmatite $\left(\mathrm{Na}_{2} \mathrm{Fe}^{2+}{ }_{5} \mathrm{TiSi}_{6} \mathrm{O}_{20}\right)$ and yellow fibrous astrophyllite $\left((\mathrm{K}, \mathrm{Na})_{3}\left(\mathrm{Fe}^{2+}\right)_{7} \mathrm{Ti}_{2} \mathrm{Si}_{8} \mathrm{O}_{26}(\mathrm{OH})_{4}\right)$ (Figs. 2c, 3b). The primary REE-minerals of both

132 the northern and southern hypersolvus granite are monazite-(Ce) and fluornatropyrochlore. The 133 monazite-(Ce) crystals are small and euhedral, and occur as inclusions in the perthitic alkali feldspar. Fluor-natropyrochlore is more abundant, and occurs as pyramidal crystals in the groundmass, or as inclusions in the alkali feldspar. The oikocrystic and pegmatitic textured 
samples contain a much smaller proportion of primary REE minerals than the fine-grained varieties of the same unit. Fluorite is an abundant accessory mineral and forms small to large, rounded, translucent to purple inclusions in sodic amphibole or is disseminated interstitially through the rock. It is usually rimmed by the Y-rich fluorite-fluocerite solid solution, which is brighter in BSE images (Fig. 3a). Locally, gagarinite-(Y) occurs in association with fluorite and the fluorite-fluocerite solid solution, and is interpreted to be secondary.

\subsection{Transsolvus granite and enclaves}

The transsolvus granite unit, which contains abundant fine-grained, dark grey ellipsoidal enclaves, surrounds and partially intruded the hypersolvus granite. The unaltered part of this intrusion at the center of the pluton is composed of the same major minerals as the hypersolvus granite, i.e., perthitic alkali feldspar, arfvedsonite and quartz. However, in contrast to the hypersolvus granite, microcline and albite form an essential part of the groundmass, indicating that the transsolvus granite crystallized at a lower temperature and/or higher $\mathrm{pH}_{2} \mathrm{O}$ than the hypersolvus granite (Tuttle and Bowen, 1958). Amphibole in this granitic facies forms prismatic phenocrysts that locally contain inclusions of microcline and albite (Fig. 3c), but in contrast to amphibole in the hypersolvus granite, they rarely contain fluorite inclusions. Locally, the amphibole has been replaced by aegirine (Fig. 2d) and, in the more heavily altered parts of the pluton, hematite. Quartz forms round crystals that display a snowball texture, in which primary albite nucleated on the faces of the crystal. Alkali zirconosilicates, such as vlasovite and elpidite, occur intersitially, and usually occupy a larger proportion of the rock volume than in the hypersolvus granite. Narsarsukite $\left(\mathrm{Na}_{2}\left(\mathrm{Ti}_{1} \mathrm{Fe}^{3+}\right) \mathrm{Si}_{4}(\mathrm{O}, \mathrm{F})_{11}\right)$, the sole sodium-titanosilicate, occurs as large tabular beige poikilitic crystals, and is observed in the dark grey enclaves and in a number of transsolvus granite samples. Titanite has been reported to occur in the altered parts 
159 (Birkett et al., 1996), and is an abundant phase in the pegmatites of the transsolvus granite (Gysi 160 et al., 2016). The primary REE minerals are fluornatropyrochlore, monazite-(Ce) and gagarinite-

161 (Ce), which was replaced by bastnäsite-(Ce). Fluorbritholite-(Ce) occurs sparsely and 162 interstitially in association with fluorite. Fluorite occurs as a late magmatic, interstitial 163 (translucent) or hydrothermal (purple) phase, and is less abundant than in the hypersolvus 164 granite. The transsolvus granite hosts a large number of NYF-type pegmatites with border zones 165 of K-feldspar, quartz, sodic amphibole and alkali zirconosilicates, and a strongly altered core 166 with quartz, fluorite and exotic REE minerals, as well as zircon and pyrochlore (Gysi and 167 Williams-Jones, 2013). These pegmatites host the bulk of the rare metal mineralization in the deposit and have been the target of recent mineral exploration.

170 alkali feldspar phenocrysts, quartz eyes and fine-grained subhedral to phenocrystic arfvedsonite

171 in the groundmass (Fig. 3d). Locally, this unit was intruded by a leucocratic transsolvus granite, 172 which, texturally and mineralogically, is similar to the dark grey enclaves observed in the 173 transsolvus granite. This unit has a bulk composition slightly less evolved than, and a mineralogy 174 similar to that of the transsolvus granite. The fine-grained, dark grey enclaves hosted by the transsolvus granite are ellipsoidal in shape, range from a few $\mathrm{cm}$ up to $50 \mathrm{~cm}$ in diameter and have sharp edge contacts in most cases. These enclaves are composed of perthitic alkali feldspar

177 phenocrysts embedded in a matrix of fine-grained quartz, microcline, albite and finely distributed 178 subhedral and locally phenocrystic sodic amphibole, which gives them their dark appearance.

\subsection{Material}


181 The major and trace element compositions of the amphibole-group minerals were determined in

18222 least-altered rock samples. All granite types occurring in the unaltered portion of the Strange

183 Lake pluton were considered (Fig. 1). Bulk-rock compositions of the samples were provided by

184 Quest Rare Minerals Ltd., and represent the results of analyses by Actlabs using XRF (X-ray

185 fluorescence) for $\mathrm{Nb}$, ISE-MS (ion selective electrode) for $\mathrm{F}$, fusion-ICP-OES for major

186 elements and fusion ICP-MS for most trace elements.

187

188

189

190

191

192

193

194

195

196

197

198

199

200

201

202

\subsection{Electron-microprobe analyses}

The composition of the amphibole-group minerals in $30 \mu \mathrm{m}$ thick, carbon-coated polished thin sections was determined using a JEOL JXA-8900L electron microprobe (EMP) at the Department of Earth and Planetary Sciences, McGill University. The beam current was $20 \mathrm{nA}$, the acceleration voltage $20 \mathrm{kV}$, and the beam diameter $10 \mu \mathrm{m}$. Counting times and standards used for analyses as well as detection limits based on repeated standard analyses are listed in the appendix. To ensure analysis of the same spots by both EMP and LA-ICP-MS (see below), backscattered electron micrographs (BSE) of the analyzed grains were taken.

\subsection{Laser-ablation analyses}

Laser ablation ICP-MS (LA-ICP-MS) analyses were conducted on 16 samples using a NewWave 213 nm Nd-YAG laser-ablation system and a Thermo Finnigan iCapQc quadrupole ICP-MS at the Department of Earth and Planetary Sciences, McGill University. Six samples were analysed at Université du Québec à Montreal (UQAM) using a Photon Machine G2 shortpulse (4ns) laser-ablation system (193 nm excimer) and a $\mathrm{Nu}$ AttoM high-resolution magnetic sector ICP-MS. The amphibole-group minerals were analyzed for selected major and trace elements in the same $30 \mu \mathrm{m}$-thick polished sections. NIST SRM 610 glass was used as the 
primary standard, and EMP data for both $\mathrm{Si}$ and $\mathrm{Ti}$ were used as internal references. The

204

205

206

207

208

209

210

211

212

213 analyses were performed with a $5 \mathrm{~Hz}$ repetition rate, on material ablated from a $20 \mu \mathrm{m}$ diameter pit. Data reduction was carried out using the software, Iolite, version 2.5. The estimated precision is $5-10 \%$ for each element.

\subsection{Amphibole formulae}

The amphibole-group mineral formulae were calculated on the basis of $\mathrm{O}+\mathrm{OH}+\mathrm{F}=24$ atoms per formula unit (apfu) and $\mathrm{OH}=2-2 \mathrm{Ti}$, using the amount of $\mathrm{Ti}^{4+}$ as a proxy for the (maximum) oxy-component in the mineral structure (Hawthorne et al., 2012). The formula calculation was performed following the latest IMA 2012 recommendations (Hawthorne et al., 2012; Oberti et al., 2012) using the Excel spreadsheet of Locock (2014). On the basis of a preliminary formula calculation after Leake et al. (1997), the following cation normalization schemes were chosen: $\mathrm{Si}-\mathrm{Ca}+\mathrm{Li} \leq 15, \mathrm{Si}-\mathrm{Na} \geq 15$ and $\mathrm{Si}-\mathrm{K} \leq 16$. As some fluorite inclusions in the amphibole from the hypersolvus granite were too small to be detected by imaging, analyses returning high concentrations of both $\mathrm{Ca}(>3$ wt. \%) and $\mathrm{F}(>2$ wt. \%) were removed from the dataset.

\section{RESULTS}

\subsection{Bulk rock compositions}

The average (median) major and trace element bulk-rock compositions of the unaltered Strange Lake granites are reported in Table 1 . The agpaitic indices (molar $[\mathrm{Na}+\mathrm{K}) / \mathrm{Al}]$ ) of all units are $>1$ and hence classify the rocks as peralkaline. The granites generally have low $\mathrm{Ca}$ and $\mathrm{Mg}$ and high alkali, Fe, F, Zn, Rb, Zr, Nb and REE concentrations. The evolution of the granites is reflected by decreasing $\mathrm{Al}$, and increasing $\mathrm{Si}, \mathrm{Fe}$ and incompatible element concentrations (i.e., REE, $\mathrm{Nb}$, Zr). The agpaitic index also increases with evolution. The fine-grained southern hypersolvus 
granite, based on the above mentioned element concentrations, is interpreted to represent the least evolved rock unit. The oikocrystic / pegmatitic textured members of this unit has higher Si and Fe concentrations, a higher agpaitic index and slightly elevated REE and Zr concentrations. The concentrations of the HFSE (REE, Th, U, Nb, Zr, Hf) in the northern hypersolvus granite are higher, whereas $\mathrm{Al}$ concentrations are lower than those in the southern hypersolvus granite, suggesting that it is more evolved. The transsolvus granite generally has high $\mathrm{Si}, \mathrm{REE}, \mathrm{Zr}, \mathrm{Nb}$, $\mathrm{Rb}$ and $\mathrm{F}$ concentrations and significantly lower $\mathrm{Al}$ and $\mathrm{Ca}$ concentrations than the hypersolvus granite, and is considered to be the most evolved member of the suite. The dark grey enclaves hosted in the transsolvus granite have high $\mathrm{Al}, \mathrm{K}$ and $\mathrm{Ca}$, and low $\mathrm{Na}, \mathrm{Fe}, \mathrm{Ti}, \mathrm{Zr}$ and $\mathrm{Nb}$ concentrations compared to the other granite types. Their REE concentrations are lower than those of their host, but higher than those of the hypersolvus granites.

\subsection{Formula assignments}

The amphibole-group minerals have the general structural formula, $\mathrm{AB}_{2} \mathrm{C}_{5} \mathrm{~T}_{8} \mathrm{O}_{22} \mathrm{~W}_{2}$. The A-site of the Strange Lake amphiboles is occupied by $\mathrm{Na}^{+}$and minor $\mathrm{K}^{+}$, and the $\mathrm{B}$-site by $\mathrm{Na}^{+}$and $\mathrm{Ca}^{2+}$, which assigns them to the alkali group. The octahedral $\mathrm{C}$-site is occupied by $\mathrm{Ti}^{4+}, \mathrm{Zr}^{4+}$, $\mathrm{Al}^{3+}, \mathrm{REE}^{3+}, \mathrm{Fe}^{3+}, \mathrm{Zn}^{2+}, \mathrm{Mn}^{2+}, \mathrm{Fe}^{2+}, \mathrm{Mg}^{2+}$ and $\mathrm{Li}^{+}$. The tetrahedral T-site is occupied by $\mathrm{Si}^{4+}$, ${ }^{\mathrm{T}} \mathrm{Al}^{3+}$ and in some cases ${ }^{\mathrm{T}} \mathrm{Ti}^{4+}$. The $\mathrm{W}$-site is dominated by the anions $\mathrm{F}^{-}, \mathrm{Cl}^{-}$and $\mathrm{OH}^{-}$, which assigns the amphiboles to the hydroxy-fluoro-chloro-group, where ${ }^{\mathrm{W}} \mathrm{F}>{ }^{\mathrm{W}} \mathrm{OH},{ }^{\mathrm{w}} \mathrm{Cl}$, and a "fluoro"-prefix is assigned to the amphibole name, which was the case for the majority of the crystals analyzed (see Table 2). In the matter of nomenclature, we have followed the latest IMA recommendations (Hawthorne et al., 2012; Oberti et al., 2012). 
The C-site has a consistent under-occupancy ( $<5 \mathrm{apfu}$ ), whereas the A-site has an overoccupancy (> 1 apfu) (see Table 2). Despite using a variety of calculation procedures (Hawthorne et al., 2012; Leake et al., 1997; Oberti et al., 2012), normalization schemes, and varying the $\mathrm{Fe}^{2+} / \mathrm{Fe}^{3+}$ ratios and oxo-components, we were unable to reduce the under-occupancy and over-occupancy of the C- and A-sites, respectively. This issue has been reported to be common for alkali amphiboles in peralkaline rocks, such as arfvedsonite or riebeckite, by other researchers, who have deemed it to be an irresolvable artefact (Czamanske and Dillet, 1988; Hawthorne, 1976; Hawthorne et al., 1993). Hawthorne (1976) suggested that some of the B-site cations, notably $\mathrm{Ca}^{2+}$, theoretically could be accommodated in the $\mathrm{C}$-site on the basis of bondlength constraints. This would result in a total C-site occupation closer to $5 \mathrm{apfu}$, and shift the excess A-site cations to the B-site.

The occupancy of the A- and B-sites determines whether the amphiboles analyzed belong to the sodic subgroup (arfvedsonite, leakeite) or the sodic-calcic subgroup (katophorite), in which ${ }^{\mathrm{B}} \mathrm{Ca}$ $>0.5$. Ferro-ferri-katophorite was identified in the least evolved fine- to medium-grained samples of the southern hypersolvus granite, exclusively. All the other amphiboles belong to the sodic subgroup, and in the cases of a calculated $\mathrm{Fe}^{2+} / \mathrm{Fe}^{3+}$ ratio of 1.1 to 2.3 , have been classified as arfvedsonite. The solid solution between the endmembers, arfvedsonite and katophorite, is displayed in Figure 4a. In principle, the location of endmember arfvedsonite could lie anywhere on the Na-K axis, as a potassic endmember has not been shown to exist in nature. The occupancy of the C-site divides the sodic amphibole subgroup into arfvedsonite and ferro-ferri-leakeite; the latter has ${ }^{\mathrm{C}} \mathrm{Li}>0.5$ apfu and a $\mathrm{Fe}^{2+} / \mathrm{Fe}^{3+}$ ratio between 0.7 and 1.3. Ferro-ferri-leakeite is the principal amphibole in the transsolvus granite but also occurs in the northern hypersolvus granite. The fluoride-rich-variety (ferro-ferri-fluor-leakeite) was detected mainly in the 
transsolvus granite and its enclaves, whereas the fluoride-poor variety occurs predominantly in the northern hypersolvus granite. The composition of the analyzed solid-solution between the endmembers, arfvedsonite and ferro-ferri-leakeite, is displayed in Figure $4 \mathrm{~b}$. The slope of the trend from the arfvedsonite to leakeite endmembers indicates an increase in $\mathrm{Fe}^{3+}$ with increasing $\mathrm{Li}^{+}$. The end-member stoichiometric formulae of the amphibole-group minerals present in the unaltered granites of the Strange Lake pluton are listed in Table 3.

\subsection{Major elements}

The major element compositions of the analyzed amphibole are reported in Table 4 (mean values) and illustrated in Figure 5 relative to their Al content. Aluminum was chosen because the Al content of amphibole is commonly a reliable indicator of the differentiation of the corresponding magma, if alkali feldspar fractionation (perthite phenocrysts) was the major control on magma evolution (Hawthorne et al., 2001; Piilonen et al., 2013). As shown in Figure 5a, the Ca content decreases with decreasing $\mathrm{Al}$ content in a ratio slightly greater than $1: 1$, and is highest and shows the greatest range ( 0.3 to $0.6 \mathrm{apfu})$ in the amphibole of the fine-grained granite from the southern hypersolvus granite. The Ca content is lower in the pegmatitic and oikocrystic textured samples of the same unit (0.1 to $0.35 \mathrm{apfu})$. Amphibole of the northern hypersolvus granite has a much lower Ca concentration, between 0.05 and 0.2 apfu. The lowest Ca concentrations are for amphibole in the enclaves and the transsolvus granite $(\leq 0.1 \mathrm{apfu})$ (Fig. 5a). Sodium exhibits the opposite trend to $\mathrm{Ca}$, with concentrations increasing with decreasing $\mathrm{Al}$ content. In the fine- to medium-grained samples of the southern hypersolvus granite, Na-contents are relatively low, between 2.1 and 2.6 apfu, whereas in the oikocrystic to pegmatitic samples, the $\mathrm{Na}$ contents are consistently higher, between 2.6 and 2.9 apfu, and are similar to those of the amphibole from the northern hypersolvus granite, the enclaves and the transsolvus granite (Fig. 
5b). The Ti content of amphibole in the fine- to medium-grained samples of the southern hypersolvus granite has a similar range to that in the northern hypersolvus granite, i.e., from 0.08 to 0.22 apfu versus 0.1 to 0.21 apfu, but because of the much lower Al content of the amphibole in the northern hypersolvus granite samples, the two datasets display separate Ti-Al trends (Fig. 5c). Amphiboles in the oikocrystic to pegmatitic samples of the southern hypersolvus granite, the transsolvus granite and the enclaves all have relatively low Ti contents (0.06 to 0.16 apfu) (Fig. 5c). Silica in amphibole behaves similarly to $\mathrm{Na}$, increasing in concentration with decreasing $\mathrm{Al}$ concentration. The lowest silica concentrations are those of the fine- to medium-grained samples 300 of the southern hypersolvus granite (7.4 to $7.7 \mathrm{apfu}$ ) (Fig. 5d); the oikocrystic to pegmatitic samples display the largest range in amphibole Si content, from 7.4 to 8.0 apfu. Amphibole in the northern hypersolvus granite, the enclaves and the transsolvus granite has $\mathrm{Si}$ contents from 7.7 to 7.9, 7.6 to 7.9 and 7.6 to 8 apfu, respectively (Fig. 5d). Manganese contents of amphibole are highest in the northern hypersolvus granite $(0.09-0.12)$ and show the greatest range in the transsolvus granite $(0.06-0.12)$ (Fig. 5e). They are broadly similar for amphibole from the enclaves and the southern oikocrystic to pegmatitic hypersolvus granite $(0.07-0.10)$, and range from 0.08 to 0.11 for amphibole from the fine-grained southern hypersolvus granite. The calculated $\mathrm{Fe}^{2+} / \mathrm{Fe}^{3+}$ ratios correlate weakly with the Al concentrations. Amphibole from the finegrained southern hypersolvus granite generally has the highest $\mathrm{Fe}^{2+} / \mathrm{Fe}^{3+}$ ratio; amphibole from the enclaves, the northern hypersolvus granite and many of the transsolvus granite samples has a low ratio (Fig. 5f). Zinc concentrations are slightly elevated for the amphibole from the finegrained samples of the southern hypersolvus granite (avg. 0.08 apfu) and the enclaves (avg. 0.07 apfu), compared to the amphibole of the northern hypersolvus granite, the transsolvus granite and the oikocrystic and pegmatitic samples of the southern hypersolvus granite (all avg. 0.05 
apfu) (Fig. 5g). Fluorine concentration is highest in the amphibole of the transsolvus granite (1.0

- $1.4 \mathrm{apfu})$, lowest for the crystals of the (fine-grained) southern hypersolvus granite $(0.2-0.8$ apfu) and is intermediate (avg. $1 \mathrm{apfu}$ ) for all the other granite units.

The amphibole phenocrysts of the transsolvus granite differ only slightly in composition from core to rim (Fig. 6; Table 5). The phenocryst cores have total $\mathrm{Al}$ and $\mathrm{Si}$ contents averaging 0.06 (apfu) and 7.9 (apfu), respectively, a considerable range in Ca concentration ( $~ 0.1$ to 0.5 apfu, avg. 0.03 apfu), $\mathrm{Na}$ and $\mathrm{K}$ contents averaging 2.8 and 0.33 apfu, respectively, a $\mathrm{Fe}^{3+}$ content averaging $1.8 \mathrm{apfu}$, a Mg content averaging $0.03 \mathrm{apfu}$, a total Ti content of 0.09 apfu (avg.), Mn and $\mathrm{Zn}$ contents averaging 0.07 and 0.05 apfu (avg.), respectively, and a F content averaging 1.2 apfu. The phenocryst rims have lower concentrations of Al (avg. 0.06 apfu), Si (7.7 apfu), Ca (avg. 0.02 apfu), $\mathrm{Na}$ (avg. 2.8 apfu), Mg (avg. 0.02) and $\mathrm{F}$ (avg. $1.1 \mathrm{apfu}$ ), and higher concentrations of total $\mathrm{Fe}^{3+}$ (avg. 2.2 apfu), K (avg. 0.4 apfu), total Ti (0.1 apfu), Mn and Zn (avg. 0.09 and 0.07 apfu, respectively).

\subsection{The REE and other trace elements}

The shapes of the chondrite-normalized amphibole REE profiles (Sun and McDonough, 1989) are similar for all the granite units and, in general, are characterized by relatively flat light and middle REE parts, a marked negative Eu-anomaly $\left(\mathrm{Eu} / \mathrm{Eu}^{*}=0.04-0.66\right)$ and an enrichment in the HREE (Fig. 7). However, the absolute REE concentrations differ considerably. The amphiboles of the fine-grained samples of the southern hypersolvus granite have the highest total REE concentration, on average (median value) $0.16 \pm 0.03$ wt. \% (Table 4). By contrast, oikocrystic to pegmatitic samples of the same unit have much lower amphibole REE concentrations, on average, $0.04 \pm 0.01$ wt. $\%$. The total REE concentrations of amphibole in the 
northern hypersolvus granite are intermediate between those of the fine-grained and oikocrystic to pegmatitic southern hypersolvus granite, averaging $0.07 \pm 0.02 \mathrm{wt} \%$. Amphiboles of the transsolvus granite and its enclaves have much lower total REE concentrations, averaging $0.01 \pm$ 0.002 wt. $\%$ and $0.04 \pm 0.01$ wt. $\%$, respectively (Table 4). The amphibole REE concentrations are between $10^{2}$ and $10^{3}$ times the chondrite values (Fig. 7c, e).

The contents of the individual REE in the amphiboles are significantly lower (in the case of the light REE (LREE), more than an order of magnitude lower) than their respective bulk host rock concentrations, except for the heaviest of the REE, $\mathrm{Yb}$ and $\mathrm{Lu}$, which are significantly higher (Fig. 7). In the case of the fine-grained southern hypersolvus granite, the exception extends to the middle REE and for $\mathrm{Yb}$ and $\mathrm{Lu}$ the content in amphibole is about four times higher than the bulk rock content (Fig. 7a). The concentrations of $\mathrm{Yb}$ and $\mathrm{Lu}$ of the amphiboles from the northern hypersolvus granite exceed the bulk rock concentrations to a similar degree (Fig. 7c). The largest difference between amphibole and bulk rock REE concentrations is exhibited by the transsolvus granite, which has considerably higher concentrations in the bulk rock except for $\mathrm{Yb}$ and $\mathrm{Lu}$; the amphibole in this unit also shows the steepest chondrite-normalized rise in HREE concentration (Fig. 7e). The amphiboles in the dark-grey enclaves hosted by this unit have elevated light to middle REE compositions compared to that of amphibole in the transsolvus granite, whereas the As is the case for the REE, the contents of most of the other trace elements are considerably lower in the amphibole-group minerals than in the average bulk-rock (other than in the southern 357 fine- to medium-grained hypersolvus granite). Conspicuous exceptions are $\mathrm{Nb}, \mathrm{Zr}$ and $\mathrm{Hf}$, which in addition to being present in zircon, monazite-(Ce) and the pyrochlore group minerals, are also accommodated by the amphibole. The chondrite-normalized trace element profiles for the 
amphiboles in all granite units have negative $\mathrm{Ba}, \mathrm{U}, \mathrm{K}, \mathrm{Pb}, \mathrm{Sr}, \mathrm{Eu}$, Ti and $\mathrm{Y}$ anomalies, and positive $\mathrm{Th}, \mathrm{Nb}$, Ta, Sn, REE, $\mathrm{Zr}$ and $\mathrm{Hf}$ anomalies, whereas the average bulk rock has negative $\mathrm{Ba}, \mathrm{K}, \mathrm{Pb}, \mathrm{Sr}, \mathrm{Eu}$, and $\mathrm{Ti}$ and positive Th, U, Nb, Ta, REE, Zr, Hf and Y anomalies (Fig. 7). Thus, although the behavior of most elements in the amphibole is similar to that in the host rock, U and Y show opposite behavior, i.e., their concentrations are anomalously low in the amphibole and high in the bulk rock. Zirconium concentrations are lowest in amphibole from the southern hypersolvus granite (avg. 0.07 to $0.12 \mathrm{wt} . \%$ ), and reach more than double these concentrations in amphibole from the northern hypersolvus granite $(\sim 0.26$ wt. \%). Concentrations are intermediate between these extremes in the amphibole of the transsolvus granite $(\sim 0.14$ wt. $\%)$ and enclaves ( 0.21 wt. \%). Lithium concentrations, on average, are lowest in amphibole of the southern hypersolvus granite (avg. 0.15 to $0.16 \mathrm{wt}$ \%), significantly higher in amphibole of the northern hypersolvus granite (avg. 0.31 wt. \%) and by far the highest in amphibole of the transsolvus granite (avg. 0.58 wt. \%) and enclaves (avg. 0.48 wt. \%). However, they vary greatly among samples, and, to a lesser extent, among crystals in the same sample (see Table 4).

Differences in the chondrite-normalized REE profile are particularly marked among the five amphibole types identified in this study. Sodium- and calcium-rich ferro-ferri-katophorite as well as arfvedsonite have the highest total REE concentrations; their average $\mathrm{La}_{\mathrm{N}} / \mathrm{Yb}_{\mathrm{N}}$ ratios are 0.23 and 0.49, respectively (Fig. 8). Fluoro-arfvedsonite and Li-rich ferro-ferri-leakeite both have intermediate REE concentrations and a more prominent HREE enrichment with an average $\mathrm{La}_{\mathrm{N}} / \mathrm{Yb}_{\mathrm{N}}$ ratio of 0.09 and 0.14 , respectively. Ferro-ferri-fluoro leakeite has by far the lowest total REE concentration, and it exhibits the strongest relative HREE enrichment with an average $\mathrm{La}_{N} / \mathrm{Yb}_{\mathrm{N}}$ ratio of. 0.04

\section{DISCUSSION}




\subsection{Amphibole composition as a tracer of granite differentiation}

384 The variations in the major and trace element chemistry of amphibole in the Strange Lake pluton 385 are interpreted to reflect the evolution of the granitic melt. The earliest intrusive phase was the hypersolvus granite, which has been subdivided into a southern and a northern part on the basis of compositional and mineralogical differences. In both units, the amphiboles, mainly (fluoro)arfvedsonite $(n=49)$ and minor (fluoro)-katophorite $(n=6)$, occur interstitially to perthite and quartz, and thus were the last of the main rock-forming minerals to crystallize. By contrast, in the more evolved transsolvus granite, the amphibole, mostly fluoro-arfvedsonite and ferro-ferri391 (fluoro)-leakeite $(\mathrm{n}=55)$, occurs as phenocrysts together with minor perthite, and therefore crystallized prior to the emplacement of this granite facies. This difference in the timing of crystallization of the amphibole, as we will show below, played a crucial role in determining the extent to which incompatible elements, such as the REE and other HFSE, were incorporated in its crystal structure.

\subsection{Magma evolution monitored by A-and B-site occupancy}

In the hypersolvus granite, the $\mathrm{A}$ - and $\mathrm{B}$-sites are occupied mainly by $\mathrm{Na}$, but also by considerable $\mathrm{Ca}$ in some samples of the southern hypersolvus granite (see Fig. 4a). The high density of fluorite inclusions also suggests that the early melt was relatively rich in $\mathrm{Ca}$. The occupation of the $\mathrm{B}$-site by the bivalent $\mathrm{Ca}$ ion was balanced by $\mathrm{Al}^{3+}$ at the $\mathrm{T}$-site. With increasing degree of differentiation, $\mathrm{Na}^{+}$substituted for $\mathrm{Ca}^{2+}$ and $\mathrm{Si}^{4+}$ for $\mathrm{Al}^{3+}$ (see Figs. 5a, b, d). This coupled substitution can be expressed by the reaction:

$$
{ }^{\mathrm{B}} \mathrm{Ca}^{2+}+{ }^{\mathrm{T}} \mathrm{Al}^{3+} \rightarrow{ }^{\mathrm{B}} \mathrm{Na}^{+}+{ }^{\mathrm{T}} \mathrm{Si}^{4+}
$$


404 A similar correlation of decreasing $\mathrm{Ca}$ and increasing $\mathrm{Si}$ in amphibole with magmatic evolution

405 has been documented for silica-undersaturated alkaline intrusive suites, namely Ilímaussaq in

406 southern Greenland (Marks et al., 2004), the Khibiny complex in the Kola Peninsula of Russia

407 (Konopleva et al., 2008), and the alkaline pegmatites of the silica-undersaturated to -saturated

408 Larvik plutonic suite of the Oslo Rift in Southern Norway (Piilonen et al., 2013). In these three

409 locations, the amphibole composition evolved from calcic to sodic-calcic to sodic varieties with

410 increasing degree of differentiation, reflecting the increasing alkalinity of the corresponding

411 magma.

412 As the Ca content is highest in amphibole of the fine- to medium-grained southern hypersolvus

413 granite (see Fig. 5a), we interpret this unit to be the earliest and least evolved intrusive facies of

414 the Strange Lake pluton. The much lower content of $\mathrm{Ca}$ in amphibole of the oikocrystic to

415 pegmatitic textured granites from the same unit is consistent with the interpretation that these

416 rocks crystallized from residual melts. Consistent with these interpretations, the northern

417 hypersolvus granite, in which amphibole has a relatively low $\mathrm{Ca}$ (and $\mathrm{Al}$ ) concentration,

418 represents the intrusion of a separate and more evolved batch of magma.

419 The amphibole of the transsolvus granite generally has low $\mathrm{Ca}$ - and $\mathrm{Al}-$, as well as high $\mathrm{Na}-$ and

420 Si-concentrations (see Fig. 5a, b, d), which all point towards a significantly more evolved melt.

421 As the amphibole of this unit crystallized early (it occurs as phenocrysts), as opposed to the

422 hypersolvus granite, the transsolvus granitic melt was more evolved from the outset. The

423 evolution of this melt is monitored by the compositional differences between phenocryst cores

424 and rims. For example, $\mathrm{Ca}, \mathrm{Na}$ and $\mathrm{Al}$ concentrations decrease from core to rim (see Fig. 6,

425 Table 4). Decreasing $\mathrm{Ca}$ and $\mathrm{Al}$ concentrations mirror the evolution to a more alkaline magma

426 composition, which was caused by alkali feldspar fractionation (Boily and Williams-Jones, 
1994). The unexpected depletion of $\mathrm{Na}$ in the rims, however, is likely an artefact of the exsolution of a Na-rich fluid at a later stage of crystallization (Salvi and Williams-Jones, 1996; Roelofsen, 1997; Gysi et al., 2016), and/or the onset of albite crystallization. Not surprisingly, given the generally very low $\mathrm{Ca}$ and $\mathrm{Al}$ contents (close to zero) (Fig. 5a) and very high $\mathrm{Na}$ (Fig. $5 b)$ content of the amphibole, compared to those of the hypersolvus granite, the transsolvus granite is the most evolved of the intrusive units considered in this study. The enclaves in this unit contain amphibole with slightly higher $\mathrm{Ca}$, and $\mathrm{Al}$, and lower $\mathrm{K}$ and $\mathrm{F}$ concentrations than the crystals in the host granite (see Fig. 5), which points to a slightly less evolved composition. Nonetheless, their close compositional resemblance to the crystals of the transsolvus granite, indicates that they may be part of the same intrusion.

\subsection{Magma evolution monitored by the C-site occupation}

\subsubsection{Implications of the $\mathrm{Fe}^{2+} / \mathrm{Fe}^{3+}$ ratio}

The C-site of the amphibole-group minerals in the Strange Lake complex mainly hosts $\mathrm{Fe}^{2+}$ and $\mathrm{Fe}^{3+}$, but also $\mathrm{Li}^{+}, \mathrm{Mg}^{2+}, \mathrm{Mn}^{2+}, \mathrm{Zn}^{2+}, \mathrm{Ti}^{4+}$ and $\mathrm{Zr}^{4+}$ in significant proportions. The $\mathrm{Fe}^{2+} / \mathrm{Fe}^{3+}$ ratio of a magma is controlled by the $f \mathrm{O}_{2}$, and may be recorded by the amphibole composition. However, $\mathrm{Fe}^{3+}$ also becomes more or less compatible in the amphibole structure depending on its overall composition, and the exchange vectors that operate. In particular, the incorporation of $\mathrm{Na}$ at the expense of $\mathrm{Ca}$ is charge-balanced by $3+$ elements in the exchange vector: $\mathrm{Ca}+\left(\mathrm{Mg}, \mathrm{Fe}^{2+}\right)$ $=\mathrm{Na}+\left(\mathrm{Al}, \mathrm{Fe}^{3+}\right)$. When $\mathrm{Al}$ contents are depleted in the melt (e.g., increasing peralkalinity), $\mathrm{Fe}^{3+}$ becomes progressively more important in this exchange vector. In this case, the amphibole $\mathrm{Fe}^{2+} / \mathrm{Fe}^{3+}$ ratio will vary with the $\mathrm{Na} / \mathrm{Ca}$ ratio in rocks with the same major mineral paragenesis. In the late amphibole of the hypersolvus granite, $\mathrm{Fe}^{2+} / \mathrm{Fe}^{3+}$ ratios of the northern unit are lower 

that incorporation of $\mathrm{Fe}^{3+}$ in the structure, to some degree, was tied to the lower Ca content of the amphibole. However, as the correlation between $\mathrm{Fe}^{2+} / \mathrm{Fe}^{3+}$ and $\mathrm{Na} / \mathrm{Ca}$ is not $1: 1$, it is likely that there was an additional effect on the $\mathrm{Fe}^{2+} / \mathrm{Fe}^{3+}$ ratio, e.g., oxidation. Oxidation of a magma commonly occurs following fluid exsolution from the magma, due to decomposition of $\mathrm{H}_{2} \mathrm{O}$ to $\mathrm{H}_{2}$ and $1 / 2 \mathrm{O}_{2}$, and the subsequent loss of the much faster diffusing $\mathrm{H}_{2}$ (Czamanske and Wones, 1973). As the amphibole crystallized late in this facies, it can be inferred that the cooling intrusion had experienced some degassing and subsequent fluid loss at this point. Even in the freshest units (e.g., the hypersolvus granite) of the Strange Lake pluton, there is evidence of $\mathrm{H}_{2} \mathrm{O}$-saturation at a late stage of in-situ evolution, e.g., the albitization of $\mathrm{K}$-feldspar, the hydrothermal alteration of primary REE-minerals and the crystallization of hydrothermal REEphases, such as gagarinite-(Y) after fluorite (Gysi et al., 2016; Vasyukova and Williams-Jones, 461 2016).

The amphibole of the transsolvus granite and enclaves generally has a low $\mathrm{Fe}^{2+} / \mathrm{Fe}^{3+}$ ratio (see Fig. 5f). In addition, the phenocrysts rims have elevated $\mathrm{Fe}^{3+}$ concentrations compared to their cores (see Fig. 6c) which can be related to increasing $f \mathrm{O}_{2}$. The amphibole rims may have continued to crystallize after emplacement, when the magma experienced degassing and oxidation. In addition, some correlation between $\mathrm{Fe}^{2+} / \mathrm{Fe}^{3+}$ and $\mathrm{Na} / \mathrm{Ca}$ suggests that crystal chemical effects (high $\mathrm{Na} / \mathrm{Ca}$ ratio), partially caused the low $\mathrm{Fe}^{2+} / \mathrm{Fe}^{3+}$ ratio (Fig. 9). However, as the correlations are not $1: 1$, this indicates that a process, in addition to crystal chemical effects and oxidation, caused the high $\mathrm{Fe}^{3+}$ content. In peralkaline igneous systems, high concentrations of $\mathrm{F}^{-}$and $\mathrm{OH}^{-}$in the melt allow more $\mathrm{Fe}^{3+}$ to be present at a given $f \mathrm{O}_{2}$ (Birkett et al., 1996; Giehl et al., 2013). The high proportion of $\mathrm{Fe}^{3+}$ in the amphibole was likely caused by an increasing 
472 proportion of anions, notably $\mathrm{F}^{-}$and $\mathrm{OH}^{-}$in the evolving melt. This is manifested by significantly

473 higher $\mathrm{F}$ concentrations in the amphibole phenocrysts, compared to the amphiboles of the 474 hypersolvus granite (see Table 3).

475

476

477

478

479

480

481

482

483

\subsubsection{Titanium, manganese and zinc concentrations}

The titanium concentration of the amphibole-group minerals in alkaline rocks is an important indicator of the melt evolution owing to the incompatible nature of $\mathrm{Ti}$. Indeed $\mathrm{Ti}^{4+}$ was preferentially incorporated into the late crystallizing amphibole of the hypersolvus granite and much less so in the phenocrysts of the transsolvus granite (see Fig. 5c). From bulk rock compositions, we know that both the southern and northern hypersolvus granitic magmas were relatively enriched in $\mathrm{TiO}_{2}$ (on average, 0.3 wt. \% in both units). However, the amphibole of the southern unit has a much higher $\mathrm{TiO}_{2}$ concentration (avg. 1.5 wt. \%) than the northern unit (avg.1.1 wt. \%).

The proportion of the amphibole in each granite unit was estimated using the MINSQ excel spreadsheet of Herrmann and Berry (2002), which applies a least squares method to bulk rock and mineral compositions in order to determine the normative mineralogy of a sample. Proportions of the bulk $\mathrm{TiO}_{2}$ contributed by the mineral group were estimated from the amphibole proportion and the $\mathrm{TiO}_{2}$ content. The fine-grained southern hypersolvus granite contains $\sim 14$ wt. $\%$ amphibole, which hosts $\sim 70 \%$ of the bulk $\mathrm{TiO}_{2}$. The northern hypersolvus granite contains only $\sim 11$ wt. $\%$ amphibole, which hosts about $40 \%$ of the bulk $\mathrm{TiO}_{2}$. The remaining titanium is concentrated in aenigmatite and astrophyllite, sodium-titanosilicate minerals, which are present almost exclusively in the northern hypersolvus granite (see Fig. 2d). In the southern hypersolvus granite, the missing $30 \%$ is concentrated mostly in secondary 
astrophyllite, which occurs as inclusions in the alkali feldspar. Both the transsolvus granite and its enclaves have bulk rock $\mathrm{Ti}$ concentrations of $\sim 0.2$ wt. $\%$ and significantly lower concentrations in amphibole (0.7 and 0.9 wt. \%, respectively). As the amphibole is a phenocryst phase, it did not incorporate the relatively incompatible $\mathrm{Ti}^{4+}$. However, a slight increase in total Ti concentration from phenocryst cores to rims (avg. 0.09 to $0.1 \mathrm{apfu}$ ) is consistent with the internal evolution of this unit. In both the transsolvus granite and its enclaves, about $58 \%$ of the bulk $\mathrm{TiO}_{2}$ is hosted by the amphibole. The transsolvus granite has an elevated proportion of amphibole ( 18 wt. \%), whereas the enclaves contain much lower proportions of the mineral $(\sim 12$ wt. $\%)$, due to density separation that occurred in the magma chamber. The remaining $\mathrm{TiO}_{2}$ in this unit is concentrated mostly in the Na-Ti-silicate, narsarsukite.

Several studies have reported a strong positive correlation between $\mathrm{Ti}^{4+}$ and $\mathrm{O}^{2-}$ concentrations in amphibole, which is reflected in the relationships, ${ }^{\mathrm{C}} \mathrm{Ti}=\mathrm{Ti}$ and $\mathrm{O}^{2-}=2 \mathrm{Ti}^{4+}$ with the limit of ${ }^{\mathrm{W}}[2-$ $(\mathrm{OH}, \mathrm{F}, \mathrm{Cl})]$. This means, that if the $\mathrm{F}, \mathrm{Cl}$ and Ti concentrations of the amphibole are measured, and a maximum of 2 apfu for the $\mathrm{W}$-site is assigned, the $\mathrm{OH}-$ (and $\mathrm{O}-$ ) proportion can be estimated using the relationship $\mathrm{OH}=2-(2 \mathrm{Ti}-\mathrm{F}-\mathrm{Cl})$ (Hawthorne et al., 2012; King et al., 1999; Leake, 1968; Oberti et al., 2012). Following this protocol, hydroxyl $\left(\mathrm{OH}^{-}\right)$and oxygen $\left(\mathrm{O}^{2-}\right.$ ) are essential components of the amphibole from the southern hypersolvus granite (>1 apfu) (Fig. 10), whereas in the other, more evolved granite units, $\mathrm{F}^{-}$is the dominant $\mathrm{W}$-site anion (see Figs. 5h, 11b). Abundant fluorite inclusions in the amphibole of this unit (see Fig. 3a) indicate that fluorite saturated prior to the amphibole. This suggests that in the early and least evolved magma, the late amphibole crystallized from a water-rich, F-poor, residual magma. In the northern hypersolvus residual granitic melt, more $\mathrm{F}^{-}$, in addition to oxygen, was available to be incorporated in the amphibole (see Figs. 5h, Fig. 10). In both hypersolvus granite units (south 
517 and north), high $\mathrm{Ti}^{4+}$ concentrations required significant proportions of $\mathrm{O}^{2-}(0.2$ to 0.45 apfu) to 518 balance the higher charge of the $\mathrm{C}$ site. The phenocrysts of the transsolvus granite have high 519 proportions of $\mathrm{F}^{-}$, and low proportions of $\mathrm{O}^{2-}$ and $\mathrm{OH}^{-}$occupying the $\mathrm{W}$-site (see Fig. 5h, Fig. 10). This implies a highly F-enriched melt from the outset (phenocryst cores).

521 Elevated Mn-concentrations in the amphibole of the northern hypersolvus granite compared to those of amphibole in the fine-grained samples of the southern unit (see Fig. 5e) point to a progressive increase in $\mathrm{Mn}^{2+}$ concentration with hypersolvus granite evolution. The relatively 524 incompatible behavior of $\mathrm{Mn}^{2+}$ compared to $\mathrm{Fe}^{2+}$ was likely caused by the larger ionic radius of ${ }^{\mathrm{C}} \mathrm{Mn}^{2+}(\mathrm{r}=0.83 \AA)$ over $\mathrm{Fe}^{2+}(\mathrm{r}=0.78 \AA)$ (Hawthorne et al., 2001; Shannon, 1976). Amphibole $\mathrm{Zn}^{2+}$ concentrations decrease with hypersolvus granite differentiation (see Fig. 5g), due either to the co-crystallization of another $\mathrm{Zn}$-bearing phase or the progressive replacement of the relatively compatible $\mathrm{Zn}^{2+}$ ion by more incompatible cations, such as $\mathrm{Fe}^{3+}$. The amphibole phenocrysts of the transsolvus granite generally have low but highly variable $\mathrm{Mn}^{2+}$ - and $\mathrm{Zn}^{2+}$-concentrations, from 0 to $0.12 \mathrm{apfu}$, and 0.02 to $0.14 \mathrm{apfu}$, respectively. The latter is due to the much higher $\mathrm{Mn}$ and $\mathrm{Zn}$ concentrations of the phenocryst rims compared to the cores (see Table 4), which reflects increasing evolution of the magma. A progressive build-up in both $\mathrm{Mn}$ and $\mathrm{Zn}$ in the Strange Lake amphiboles with evolution was reported by Hawthorne et al. (2001), whereas we observe this trend separately for each granite unit.

\subsubsection{The role of lithium}

Lithium is a significant component of the Strange Lake amphiboles and has been reported to be an important constituent in alkali amphiboles of highly evolved alkaline rocks elsewhere (e.g., Hawthorne et al., 1993; Hawthorne et al., 1996; Marks et al., 2004). Owing to the incompatibility 
of lithium in common rock-forming minerals, its concentration reflects the degree of melt differentiation. The amphiboles of the Strange Lake pluton have an average Li concentration of $0.3 \mathrm{apfu}$, but concentrations reach $>1.0 \mathrm{apfu}$ in some transsolvus granite samples. Lithium concentrations of $>0.5$ apfu classify a sodic amphibole as ferro-ferri-(fluoro)-leakeite, which is the case for most of the amphibole in the more evolved units. Hawthorne et al. (2001), who reported $\mathrm{Li}$ concentrations of up to 0.4 apfu for amphibole in the most evolved members of the Strange Lake pluton, concluded that the elevated Li concentration was due to its high content in the magma rather than the structure of the mineral. The generally low content of $\mathrm{Li}$ in amphibole of both the southern and northern hypersolvus granite (avg. 0.16 and $0.31 \mathrm{wt} . \%$, respectively) compared to the transsolvus granite (avg. 0.58 wt. \%) (see Table 4), despite the fact that amphibole in the hypersolvus granite was a late crystallizing phase, suggests that the hypersolvus granite magma was relatively poor in Li. In contrast, the occurrence of ferro-ferri-(fluoro)leakeite as phenocrysts in the transsolvus granite suggests that the corresponding magma was more evolved. Of significance in this regard is the large range in Li-concentrations of the amphibole phenocrysts (0.1 to $1.2 \mathrm{apfu}$ ) (Fig. 11), which suggests that they record a large part of the evolution of the magma, a conclusion that is supported by the elevated Li concentrations of crystal rims relative to their cores (see Fig. 6d).

As noted earlier, the $\mathrm{Li}^{+}$concentration of the amphiboles correlates positively with the $\mathrm{C}$-site occupancy ( $\mathrm{R}^{2} \sim 0.8$ ), and hence knowledge of the concentration of this ion is essential to reliably evaluate the amphibole formula. In particular, the calculation of the $\mathrm{Fe}^{3+}$ concentration, which is highly dependent on $\mathrm{Li}^{+}$for charge balance, can only be performed accurately if the $\mathrm{Li}^{+}$ concentration is known (Hawthorne et al., 1993). The lithium concentration in the amphiboles correlates strongly with the $\mathrm{Fe}^{3+}$ concentration $\left(\mathrm{R}^{2}=0.92\right.$ for the transsolvus granite, $\mathrm{R}^{2}=0.83$ for 
562 the hypersolvus granite) (Fig. 11), and, with increasing degree of evolution, can be expressed by

563 the coupled substitution reaction

$$
{ }^{\mathrm{C}} \mathrm{Fe}^{2+}+{ }^{\mathrm{C}} \mathrm{Fe}^{2+} \rightarrow{ }^{\mathrm{C}} \mathrm{Fe}^{3+}+{ }^{\mathrm{C}} \mathrm{Li}^{+}
$$

565 The progressive increase in $\mathrm{Li}^{+}$and $\mathrm{Fe}^{3+}$ with evolution is consistent with the increase in $f \mathrm{O}_{2}$ in 566 the hypersolvus granite, and also with the increase in melt $\mathrm{F}^{-}$and $\mathrm{OH}^{-}$in the transsolvus granite, 567 both of which were discussed earlier.

\subsection{Distribution of the REE and other trace elements}

The trace element composition of amphibole-group minerals is a function of the magma composition and the structure of the mineral (i.e., the preference of its sites for ions of a particular size and charge). In the Strange Lake granites, for example, the negative $\mathrm{Ba}, \mathrm{Pb}, \mathrm{Sr}$, and $\mathrm{Eu}$ anomalies in both the amphibole and bulk rock are likely due to voluminous plagioclase fractionation early in the crystallization history. This process is interpreted to have produced the large Mesoproterozoic anorthosite complexes of the Nain Plutonic Suite (Emslie et al., 1994; McLelland et al., 2010). Consistently low Rb concentrations, and negative U and Y anomalies in the amphibole, but not in bulk rock, on the other hand, are interpreted to have been caused by within-pluton-fractionation of K-feldspar (substitution of $\mathrm{Rb}$ for $\mathrm{K}$ ) and of $\mathrm{Y}$ - and U-rich minerals, such as gagarinite-(Y), the fluorite-fluocerite solid solution and small amounts of Ubearing thorite.

The behavior of the REE in amphibole-group minerals is governed by a combination of crystal

581 chemical constraints and magmatic processes. Several studies have concluded that the trace element composition of amphibole is dependent on the major element distribution, and, to a lesser extent, on the $\mathrm{P}, \mathrm{T}$ and $\mathrm{fO}_{2}$ conditions (Bottazzi et al., 1999; Dalpé and Baker, 2000). In 
the Gardar Province (Ilímaussaq, Puklen and Grønnedal-Ika intrusions), for example, Ca-rich amphibole- group minerals are strongly enriched in the LREE (order of magnitude), compared to the Na-rich members of the same mineral group (Marks et al., 2004). Consistent with this observation, the Ca-rich ferro-ferri-katophorite at Strange Lake is enriched in the REE by $10^{2}$ to $10^{3}$ times the chondrite values, whereas the Na-rich fluor-arfvedsonite and ferro-ferri-(fluoro)leakeite have much lower total REE concentrations, and show a stronger relative enrichment in the HREE (see Fig. 8).

The Ca-rich amphiboles are members of the earlier, less evolved hypersolvus granite, in which they crystallized as a late, interstitial phase from a small proportion of residual liquid. The residual liquid of this overall less evolved unit was relatively enriched in incompatible elements such as the REE, whereas the amphibole phenocrysts of the more evolved transsolvus granite crystallized from a relatively 'dilute' magma with low incompatible element concentrations. In contrast, the amphiboles of the Gardar Province all are late, near solidus phases in all rock types that have been investigated, e.g., augite-syenites, alkali granites, agpaites and nepheline syenites (Markl et al., 2001; Marks et al., 2004). Thus, the fact that the LREE are tied to Ca-rich amphiboles implies that another factor, in addition to the magma composition, may have been important in accommodating the REE in the crystal structure. Rare earth element concentrations in the Strange Lake amphiboles correlate positively with $\mathrm{Al}^{3+}\left(\mathrm{R}^{2}=0.59\right)$ and $\mathrm{Ca}^{2+}\left(\mathrm{R}^{2}=0.61\right)$ concentrations, and negatively with $\mathrm{Na}^{+}\left(\mathrm{R}^{2}=0.57\right), \mathrm{F}^{-}\left(\mathrm{R}^{2}=0.51\right)$ (Fig. 12) and $\mathrm{Si}^{4+}$ concentrations. This suggests that overall the REE become less compatible in the amphibole structure with increasing degree of magma evolution, or alternatively, that the nature of the major elements in the mineral structure control the accommodation of the REE. 
606 Interestingly, the amphiboles of the oikocrystic and pegmatitic samples of the southern

607 hypersolvus granite have much lower REE concentrations (avg. 0.04 wt. \%) than their host

608 (avg. 0.16 wt. \%), but similar to those of amphiboles in the northern hypersolvus granite (avg.

$609 \sim 0.07$ wt. \%) (see Table 3). In the latter amphiboles, however, the Al and Ca contents are

610 significantly lower ( 0.5 vs 1.0 wt. $\% \mathrm{Al}_{2} \mathrm{O}_{3}$ and 0.5 vs. 1.1 wt. \% $\left.\mathrm{CaO}\right)$. This is consistent with

611 the interpretation that the oikocrystic and pegmatitic granites crystallized from volatile-rich melt

612 pockets that evolved in-situ, and is further evidence that the northern hypersolvus granite

613 evolved from the southern hypersolvus granite. The decoupling of REE concentrations from

614 those of $\mathrm{Ca}$ and $\mathrm{Al}$ observed in these two rock units speaks to a factor other than the degree of

615 magma evolution in controlling the incorporation of the REE in amphibole.

616

617

619

620

621

622

\subsection{REE inter-site partitioning}

Previous studies have concluded that the REE in the amphibole structure are distributed over the $\mathrm{B}$ and $\mathrm{C}$ sites and that this distribution depends on the nature of the major elements that reside in these sites (Bottazzi et al., 1999; Tiepolo et al., 2007; Tiepolo et al., 2000). These conclusions were reached from studies of the partitioning of the REE between amphibole and melt, with the $\mathrm{D}_{\mathrm{REE}}$ showing systematic behavior controlled by the $\mathrm{B}$ and $\mathrm{C}$ site dimensions ( $c f$. Blundy and Wood, 2003). Unfortunately, these data do not extend to the amphibole compositions encountered at Strange Lake. In order to obtain a first-order estimate of the localization of the REE in sodic amphibole, apparent mineral-melt partition coefficients were calculated from the bulk rock and median sodic amphibole compositions of transsolvus granite sample 204720. Amphibole was the first major phase to crystallize in this sample, but inclusions of pyrochlore group minerals and monazite-(Ce) indicate that these minerals had likely already saturated. The median compositions of these minerals at their respective modes were subtracted from the bulk 
composition to obtain an estimate of the melt composition at the time of amphibole crystallization. This assumes that sample 204720 acted as a closed system, that it represents a melt composition, that all pyrochlore group minerals and monazite-(Ce) crystallized prior to amphibole, and that all amphibole formed at the same time. However, deviations from these assumptions mainly impact the absolute D values, whereas their systematics are unaffected.

A plot of the partition coefficients against the radii of the REE (6-fold and 8-fold coordinated radii for the C and B-sites, respectively, as given in Shannon 1976) is shown in Fig. 13. The LREE in the sodic amphiboles from Strange Lake are most compatible with the B-site (Fig. 13), as also has been shown for calcic and sodic-calcic amphiboles (Bottazzi et al., 1999). The lightest of the lanthanides, $\mathrm{La}$ and $\mathrm{Ce}$, which have ionic radii of $1.16 \AA$ and $1.14 \AA$ (at 8-fold coordination) are closest to the ideal radius of the B-site and are thus preferentially incorporated. For reference, the major elements occupying this site are $\mathrm{Na}$ and $\mathrm{Ca}$, which with ionic radii of $1.12 \AA$ and $1.18 \AA$, respectively, are slightly smaller or larger than the ideal radius. The HREE, which have ionic radii between 0.86 to $0.94 \AA$, on the other hand, are compatible with the 6 -fold coordinated $\mathrm{C}$-site, and their compatibility increases exponentially with increasing atomic number (Fig. 13). Thus, the 'heaviest' of the REE, $\mathrm{Yb}$ and $\mathrm{Lu}$ are preferentially incorporated in the crystal structure ( $D^{\text {amph-bulk }} \mathrm{Yb,Lu}>1.0$ ), which, indeed, is what is observed in the chondritenormalized REE profiles (Fig. 7). The middle REE, e.g., Gd, has the lowest apparent partition coefficient as its radius is furthest from that of the ideal radii of both the B and $\mathrm{C}$ sites and hence fits in neither site (in Fig. 13 it is shown at its 6-fold coordinated radius). The apparent D values also suggest that $D_{\text {LREE }}<D_{\text {HREE }}$, in agreement with Tiepolo et al. (2000), who showed that the LREE are incompatible in amphibole $\left(\mathrm{D}_{\mathrm{La}}^{\mathrm{amph} / 1}=0.06\right.$ to 0.5$)$, whereas the HREE are relatively 
651 compatible $\left(\mathrm{D}^{\mathrm{amph} / \mathrm{l}} \mathrm{Yb}=0.25\right.$ to 2.0$)$. The apparent (calculated) $\mathrm{D}^{\text {amph-bulk }}$ and ionic radii at 6- and 8-fold coordination are given in Table 6 .

\subsection{The role of amphibole in concentrating HREE in the pluton}

A significant proportion of the bulk REE content of the Strange Lake granites is contained in amphibole. Indeed, the REE content of amphibole in both fine-grained and oikocrystic and pegmatitic samples of the southern hypersolvus granite is similar to or exceeds that of the bulk rock, except for $\mathrm{La}$ and $\mathrm{Ce}$; the contents of the heaviest of the REE, $\mathrm{Yb}$ and $\mathrm{Lu}$, are four times higher than in the bulk rock.

Proportions of the bulk REE hosted by the mineral group were estimated from the proportion of the amphibole in each granite facies and the REE contents of the corresponding amphiboles. The amphibole of the southern hypersolvus granite (fine-grained) ( $14 \mathrm{wt} . \%)$ contains about $10 \%$ of the bulk LREE (avg. 0.1 wt. \%) and more than $35 \%$ of the bulk HREE (avg. 0.01 wt. \%) (Fig. 14). In the case of $\mathrm{Yb}$ and $\mathrm{Lu}$, the proportions increase to 55 and $70 \mathrm{wt} \%$, respectively. In the northern hypersolvus granite, REE concentrations are considerably lower than the bulk rock concentrations, except for Tm, Yb and Lu. On average, $2 \%$ of the bulk LREE (avg. 0.15 wt. \%), and $17 \%$ of the bulk HREE (avg. 0.02 wt. \%) are hosted by amphibole in this unit ( 11 wt. \%) (Fig. 14). As the bulk rock LREE concentrations of this unit are relatively high $\left(\sim 10^{3}\right.$ times chondrite values), this points to a major LREE bearing phase, e.g., monazite-(Ce), and/or pyrochlore group minerals having crystallized prior to the amphibole or that there was another sink for the LREE. The latter would be consistent with the findings of Vasyukova and WilliamsJones $(2014,2016)$ that the hypersolvus granite magma saturated with (exsolved) a fluoride liquid into which the LREE partitioned preferentially. 
Amphibole proportions in the transsolvus granite are relatively high ( 18 wt. \%), whereas their REE concentrations are particularly low ( $>1$ and $<100$ times the chondrite value). In this unit, only $0.1 \%$ of the bulk LREE (avg. 0.28 wt. \%) and $4 \%$ of the HREE (avg. 0.03 wt. \%), on average, are hosted by the amphibole (Fig. 14). As the amphiboles occur as phenocrysts in the transsolvus granite, they largely record information about the pre-emplacement composition of the magma. Given the low LREE content of the amphibole, it is possible that an early fractionating phase depleted the melt in the LREE. These phases were monazite-(Ce) and gagarinite-(Ce), which crystallized prior to or contemporaneously with the amphibole.

As mentioned earlier, some of the enclaves hosted by the transsolvus granite are interpreted to represent the quenched margin of this intrusion. Accordingly, amphibole phenocrysts in these enclaves and the host intrusion should have similar compositions. Indeed, their major element concentrations match closely those of the transsolvus granite (see Fig. 5). However, the light and middle REE contents of the amphiboles from the enclaves are generally higher than those of amphiboles in their host (see Fig. 7e); the chondrite-normalized profiles of the bulk enclaves are parallel to those of the bulk host granite, but their absolute values are slightly lower. The consistently higher light and middle REE concentrations of amphibole in the enclaves compared to their host could indicate that the amphibole crystallized from a melt relatively enriched in these elements. However, much of the amphibole in the enclaves crystallized after emplacement (quenching), which means that it crystallized from the very first and least evolved transsolvus granite magma (lower bulk REE profile, see Fig. 7e). We therefore suggest that amphibole in the enclaves crystallized slightly later than the phenocrysts in the magma chamber (transsolvus granite), resulting in an amphibole more enriched in the REE. 
The amphibole in the more altered localities of the transsolvus granite was replaced extensively by aegirine and/or hematite during hydrothermal alteration (Gysi and Williams-Jones, 2013; Gysi et al., 2016; Salvi and Williams-Jones, 1990, 1996; Vasyukova et al., 2016). As the REE content of the aegirine is orders of magnitude lower than that of the amphibole, it is very likely that the replacement of amphibole by aegirine (and hematite) led to the release of the REE, particularly the HREE to the hydrothermal fluid and the development of potentially exploitable zones of HREE mineralization.

\section{CONCLUSIONS}

We have shown that the major and trace-element compositions of amphiboles of the Strange Lake granite complex reflect the magmatic evolution of the pluton. The differentiation of the magma proceeded from the southern hypersolvus granite to the more evolved northern hypersolvus granite, two separate intrusions which both contain amphibole as a late, interstitial phase (Fig. 15a). The most evolved unit, a transsolvus granite, contains early crystallizing amphibole in the form of phenocrysts (Fig. 15b). Amphibole compositions vary from calcicsodic (ferro-ferri-katophorite) in the least evolved southern hypersolvus granite to sodic members ((fluoro)-arfvedsonite, ferro-ferri-(fluoro)-leakeite) in the other, more evolved granites.

The increasing $\mathrm{Fe}^{3+}$ concentration in amphibole with hypersolvus granite evolution was a result of crystal chemical effects ( $\mathrm{Na} / \mathrm{Ca}$ proportion) and increasing $f \mathrm{O}_{2}$ through degassing. The same trend in the phenocrysts of the transsolvus granite implies a higher compatibility of $\mathrm{Fe}^{3+}$ with increasing $\mathrm{Na} / \mathrm{Ca}$ proportions and an increase in $\mathrm{OH}^{-}$and $\mathrm{F}^{-}$concentrations in the evolving melt. Variations in Ti-concentrations indicate the presence of Na-Ti-silicates, such as aenigmatite, astrophyllite and narsarsukite, which replaced the amphibole to varying degrees in each unit. In the transsolvus granite, magma evolution is manifested by increasing $\mathrm{Ti}$, $\mathrm{Mn}$ and $\mathrm{Zn}$ 
concentrations from amphibole cores to rims. The phenocrysts of the transsolvus granite also contain significant $\mathrm{Li}$ (ferro-ferri-fluoro-leakeite) that correlates positively with $\mathrm{Fe}^{3+}$, indicating that this most evolved melt was already enriched in Li at an early stage.

The amphiboles of all units are enriched in $\mathrm{Nb}, \mathrm{Zr}$ and $\mathrm{Hf}$ and the HREE compared to the bulk rock, reflecting a combination of magmatic compositional and crystal chemical effects. In the hypersolvus granite, the late crystallization of amphiboles from a small proportion of residual magma resulted in high incompatible element concentrations, whereas the early crystallization of amphiboles in the transsolvus granite ensured relatively low concentrations of these elements, despite the overall more evolved nature of the magma. The concentrations of the relatively incompatible LREE $\left(\mathrm{D}_{\text {arf-bulk }}<0.01\right)$ are positively coupled to the amphibole Ca concentration, with the LREE preferentially incorporated in the larger B-site. The HREE were preferred by the C-site and increased in compatibility $\left(\mathrm{D}_{\text {arf/bulk }}>0.1\right)$ with increasing atomic number and decreasing ionic radius. Variations in the LREE concentrations of the amphiboles were controlled by the relative timing of crystallization of amphibole and the presence of primary LREE minerals, such as monazite-(Ce), pyrochlore group minerals and gagarinite-(Ce), as well as the exsolution of a LREE-rich fluoride melt. The uptake of the HREE by amphibole was controlled by their relative compatibility in the structure of this mineral due to their smaller radii. A significant proportion of the bulk HREE content of the Strange Lake granites was carried by the amphibole, which during subsequent hydrothermal alteration was released to the fluid and contributed to the development of potentially exploitable HREE mineralization.

\section{ACKNOWLEDGEMENTS}

A grant by Quest Rare Minerals Ltd. and a matching grant from the NSERC Collaborative Research and Development Program, both to A. E. Williams-Jones, provided financial support 
741 for this study. Quest Rare Minerals Ltd. granted access to the field area, drill core, logistical 742 support and assay data. The sample suite used for this study included outcrop samples collected 743 by Alexandre Brosseau-Liard and Robert Fritscher. Discussions with Robert F. Martin and 744 Jeanne Paquette contributed greatly to our understanding of the amphibole chemistry. Olga 745 Vasyukova provided valuable insights into the evolution of the Strange Lake magma from her 746 own research on the pluton. Lang Shi, André Poirier, Bill Minarik and Anna Jung provided 747 essential support by guiding the mineral chemical analyses and helping in the interpretation of 748 the results. The manuscript benefited considerably from thoughtful reviews by Massimo Tiepolo 749 and Kathryn Goodenough. 


\section{REFERENCES}

Abdel-Rahman, A. F. M., 1994, Alkali Amphibole: A Potential Source of Rare Earth Elements in Felsic Alkaline Rocks: Exploration and Mining Geology, v. 3, no. 2, p. 81-94.

Birkett, T. C., Trzcienski, W. E., and Stirling, J. A. R., 1996, Occurrence and compositions of some Ti-bearing minerals in the Strange Lake intrusive complex, Quebec-Labrador boundary: Canadian Mineralogist, v. 34, p. 779-801.

Blundy, J., and Wood, B., 2003, Partitioning of trace elements between crystals and melts: Earth and Planetary Science Letters, v. 210, no. 3-4, p. 383-397.

Boily, M., and Williams-Jones, A. E., 1994, The role of magmatic and hydrothermal processes in the chemical evolution of the Strange Lake plutonic complex, Quebec-Labrador: Contributions to Mineralogy and Petrology, v. 118, no. 1, p. 33-47.

Bottazzi, P., Tiepolo, M., Vannucci, R., Zanetti, A., Brumm, R., Foley, S. F., and Oberti, R., 1999, Distinct site preferences for heavy and light REE in amphibole and the prediction of D-Amph/L(REE): Contributions to Mineralogy and Petrology, v. 137, no. 1-2, p. 3645.

Camara, F., Hawthorne, F. C., Ball, N. A., Bekenova, G., Stepanov, A. V., and Kotel'nikov, P. E., 2010, Fluoroleakeite, NaNa2(Mg2Fe23+Li)Si8O22F2, a new mineral of the amphibole group from the Verkhnee Espe deposit, Akjailyautas Mountains, Eastern Kazakhstan District, Kazakhstan: description and crystal structure: Mineralogical Magazine, v. 74, no. 3, p. 521-528.

Czamanske, G. K., and Dillet, B., 1988, Alkali amphibole, tetrasilicic mica, and sodic pyroxene in peralkaline siliceous rocks, Questa Caldera, New Mexico: American Journal of Science, v. 288-A, no. 1988, p. 358-392. 
Czamanske, G. K., and Wones, D. R., 1973, Oxidation during Magmatic Differentiation, Finnmarka Complex, Oslo Area, Norway .2. Mafic Silicates: Journal of Petrology, v. 14, no. 3, p. 349-380.

Dalpé, C., and Baker, D. R., 2000, Experimental investigation of large-ion-lithophile-element-, high-field-strength-element- and rare-earth-element-partitioning between calcic amphibole and basaltic melt: the effects of pressure and oxygen fugacity: Contributions to Mineralogy and Petrology, v. 140, no. 2, p. 233-250.

Davidson, A., 1982, Petrochemistry of the Blachford Lake Complex near Yellowknife, Northwest Territories.: Maurice, E. T. (ed.) Uranium in Granites. Geological Survey of Canada, p. 71-79.

Emslie, R. F., Hamilton, M. A., and Theriault, R. J., 1994, Petrogenesis of a Midproterozoic anorthosite-mangerite-charnockite-granite (AMCG) complex - isotopic and chemical evidence from the Nain Plutonic Suite: Journal of Geology, v. 102, no. 5, p. 539-558.

Emslie, R. F., and Stirling, J. A. R., 1993, Rapakivi and Related Granitoids of the Nain Plutonic Suite - Geochemistry, Mineral Assemblages and Fluid Equilibria: Canadian Mineralogist, v. 31, p. $821-847$.

Giehl, C., Marks, M., and Nowak, M., 2013, Phase relations and liquid lines of descent of an iron-rich peralkaline phonolitic melt: an experimental study: Contributions to Mineralogy and Petrology, v. 165, no. 2, p. 283-304.

Giret, A., Bonin, B., and Leger, J. M., 1980, Amphibole Compositional Trends in Oversaturated and Undersaturated Alkaline Plutonic Ring-Complexes: Canadian Mineralogist, v. 18, p. 481-495. 
804

805

806

807

Gower, C. F., and Krogh, T. E., 2002, A U-Pb geochronological review of the Proterozoic history of the eastern Grenville Province: Canadian Journal of Earth Sciences, v. 39, no. 5, p. $795-829$.

Gysi, A. P., and Williams-Jones, A. E., 2013, Hydrothermal mobilization of pegmatite-hosted REE and $\mathrm{Zr}$ at Strange Lake, Canada: A reaction path model: Geochimica et Cosmochimica Acta, v. 122, no. 2013, p. 324-352.

Gysi, A. P., Williams-Jones, A. E., and Collins, P., 2016, Lithogeochemical Vectors for Hydrothermal Processes in the Strange Lake Peralkaline Granitic REE-Zr-Nb-Deposit: Economic Geology and the Bulletin of the Society of Economic Geologists, v. 111, p. 1241-1276.

Hawthorne, F. C., 1976, The crystal chemistry of amphiboles: V. the structure and chemistry of arfvedsonite: Canadian Mineralogist, v. 14, p. 346-356.

Hawthorne, F. C., Oberti, R., Cannillo, E., Ottolini, L., Roelofsen, J. N., and Martin, R. F., 2001, Li-bearing arfvedsonitic amphiboles from the Strange Lake peralkaline granite, Quebec: Canadian Mineralogist, v. 39, p. 1161-1170.

Hawthorne, F. C., Oberti, R., Harlow, G. E., Maresch, W. V., Martin, R. F., Schumacher, J. C., and Welch, M. D., 2012, Nomenclature of the amphibole supergroup: American Mineralogist, v. 97 , no. 11-12, p. 2031-2048.

Hawthorne, F. C., Oberti, R., Ottolini, L., and Foord, E. E., 1996, Lithium-bearing fluorarfvedsonite from Hurricane Mountain, New Hampshire: A crystal-chemical study: Canadian Mineralogist, v. 34, p. 1015-1019. 
Hawthorne, F. C., Ungaretti, L., Oberti, R., Bottazzi, P., and Czamanske, G. K., 1993, Li - an Important Component in Igneous Alkali Amphiboles: American Mineralogist, v. 78, no. 7-8, p. 733-745.

Herrmann, W., and Berry, R. F., 2002, MINSQ - a least squares spreadsheet method for calculating mineral proportions from whole rock major element analyses: Geochemistry: Exploration, Environment, Analysis, v. 2, no. 4, p. 361-368.

James, D. T., and Dunning, G. R., 2000, U-Pb geochronological constraints for paleoproterozoic evolution of the core zone, southeastern Churchill Province, northeastern laurentia: Precambrian Research, v. 103, no. 1-2, p. 31-54.

Kerr, A., and Rafuse, H., 2012, Rare-earth element (REE) geochemistry of the Strange Lake deposits: Implications for resource estimation and metallogenic models.: Current Research (2012) Newfoundland and Labrador Department of Natural Resources, v. 1, p. $39-60$.

King, P. L., Hervig, R. L., Holloway, J. R., Vennemann, T. W., and Righter, K., 1999, Oxysubstitution and dehydrogenation in mantle-derived amphibole megacrysts: Geochimica Et Cosmochimica Acta, v. 63, no. 21, p. 3635-3651.

Konopleva, N. G., Ivanyuk, G. Y., Pakhomovsky, Y. A., Yakovenchuk, V. N., Men'shikov, Y. P., and Korchak, Y. A., 2008, Amphiboles of the Khibiny alkaline pluton, Kola Peninsula, Russia: Geology of Ore Deposits, v. 50, no. 8, p. 720-731.

Kovalenko, V. I., Tsaryeva, G. M., Goreglyad, A. V., Yarmolyuk, V. V., Troitsky, V. A., Hervig, R. L., and Farmer, G. L., 1995, The Peralkaline Granite-Related Khaldzan-Buregtey Rare-Metal (Zr, Nb, Ree) Deposit, Western Mongolia: Economic Geology and the Bulletin of the Society of Economic Geologists, v. 90, no. 3, p. 530-547. 
Leake, B. E., 1968, A Catalog of Analyzed Calciferous and Subcalciferous Amphiboles Together with Their Nomenclature and Associated Minerals: Geological Society of America, Special Papers 1968, v. 98, p. 1-44.

Leake, B. E., Woolley, A. R., Arps, C. E. S., Birch, W. D., Gilbert, M. C., Grice, J. D., Hawthorne, F. C., Kato, A., Kisch, H. J., Krivovichev, V. G., Linthout, K., Laird, J., Mandarino, J. A., Maresch, W. V., Nickel, E. H., Rock, N. M. S., Schumacher, J. C., Smith, D. C., Stephenson, N. C. N., Ungaretti, L., Whittaker, E. J. W., and Guo, Y. Z., 1997, Nomenclature of amphiboles: Report of the subcommittee on amphiboles of the International Mineralogical Association, Commission on New Minerals and Mineral Names: Canadian Mineralogist, v. 35, p. 219-246.

Locock, A. J., 2014, An Excel spreadsheet to classify chemical analyses of amphiboles following the IMA 2012 recommendations: Computers \& Geosciences, v. 62, p. 1-11.

Ltd., Q. R. M., 2012, Quest announces that a revised resource estimate for the Strange Lake BZone REE deposit shows a doubling of tonnage, http://questareminerals.com/news.php, Volume 2016: Toronto, Quest Rare Minerals Ltd.

Markl, G., Marks, M., Schwinn, G., and Sommer, H., 2001, Phase equilibrium constraints on intensive crystallization parameters of the Ilimaussaq complex, South Greenland: Journal of Petrology, v. 42, no. 12, p. 2231-2258.

Marks, M., Halama, R., Wenzel, T., and Markl, G., 2004, Trace element variations in clinopyroxene and amphibole from alkaline to peralkaline syenites and granites: implications for mineral-melt trace-element partitioning: Chemical Geology, v. 211, no. 3-4, p. 185-215. 
Mayer, B., Jung, S., Romer, R. L., Pfander, J. A., Klugel, A., Pack, A., and Groner, E., 2014, Amphibole in alkaline basalts from intraplate settings: implications for the petrogenesis of alkaline lavas from the metasomatised lithospheric mantle: Contributions to Mineralogy and Petrology, v. 167, no. 989.

McLelland, J. M., Selleck, B. W., Hamilton, M. A., and Bickford, M. E., 2010, Late- to posttectonic setting of some major proterozoic anorthosite - mangerite - charnockite - granite (AMCG) suites: Canadian Mineralogist, v. 48, no. 4, p. 729-750.

Miller, R. R., 1996, Structural and textural evolution of the Strange Lake peralkaline rareelement (NYF) granitic pegmatite, Quebec-Labrador: Canadian Mineralogist, v. 34, p. $349-371$.

Miller, R. R., Heaman, L. M., and Birkett, T. C., 1997, U-Pb zircon age of the Strange Lake peralkaline complex: Implications for Mesoproterozoic peralkaline magmatism in northcentral Labrador: Precambrian Research, v. 81, no. 1-2, p. 67-82.

Mungall, J. E., and Martin, R. F., 1996, Extreme differentiation of peralkaline rhyolite, Terceira, Azores: A modern analogue of Strange Lake, Labrador?: Canadian Mineralogist, v. 34, p. 769-777.

Oberti, R., Cannillo, E., and Toscani, G., 2012, How to name amphiboles after the IMA2012 report: rules of thumb and a new PC program for monoclinic amphiboles: Periodico Di Mineralogia, v. 81, no. 2, p. 257-267.

Petrella, L., Williams-Jones, A. E., Goutier, J., and Walsh, J., 2014, The Nature and Origin of the Rare Earth Element Mineralization in the Misery Syenitic Intrusion, Northern Quebec, Canada: Economic Geology, v. 109, no. 6, p. 1643-1666. 
Piilonen, P. C., Mcdonald, A. M., Poirier, G., Rowe, R., and Larsen, A. O., 2013, Mafic Minerals of the Alkaline Pegmatites in the Larvik Plutonic Complex, Oslo Rift, Southern Norway: Canadian Mineralogist, v. 51, no. 5, p. 735-770.

Pillet, D., Chenevoy, M., and Belanger, M., 1992, Petrology of Peralkaline Granite from Lake Brisson (Central Labrador, Nouveau-Quebec) .1. Intrusion and Chemical Evolution: Canadian Journal of Earth Sciences, v. 29, no. 2, p. 353-372.

-, 1993, Petrology of Peralkaline Granite from Lake Brisson (Quebec-Labrador) .2. Mineralogy and Modes of Crystallization: Canadian Journal of Earth Sciences, v. 30, no. 12, p. 24232435.

Roelofsen, J. N., 1997, The primary and secondary mafic silicates of two alkaline anorogenic complexes: Strange Lake (Québec-Labrador) and Amba Dongar (Gujarat, India) [Ph.D.: McGill University, $321 \mathrm{p}$.

Salvi, S., and Williams-Jones, A. E., 1990, The Role of Hydrothermal Processes in the GraniteHosted Zr, Y, Ree Deposit at Strange Lake, Quebec Labrador - Evidence from Fluid Inclusions: Geochimica et Cosmochimica Acta, v. 54, no. 9, p. 2403-2418.

Salvi, S., and Williams-Jones, A. E., 1992, Reduced Orthomagmatic C-O-H-N-Nacl Fluids in the Strange Lake Rare-Metal Granitic Complex, Quebec Labrador, Canada: European Journal of Mineralogy, v. 4, no. 5, p. 1155-1174.

Salvi, S., and Williams-Jones, A. E., 1996, The role of hydrothermal processes in concentrating high-field strength elements in the Strange Lake peralkaline complex, northeastern Canada: Geochimica et Cosmochimica Acta, v. 60, no. 11, p. 1917-1932. 
Salvi, S., and Williams-Jones, A. E., 1997, Fischer-Tropsch synthesis of hydrocarbons during sub-solidus alteration of the Strange Lake peralkaline granite, Quebec/Labrador, Canada: Geochimica Et Cosmochimica Acta, v. 61, no. 1, p. 83-99.

Salvi, S., and Williams-Jones, A. E., 2006, Alteration, HFSE mineralisation and hydrocarbon formation in peralkaline igneous systems: Insights from the Strange Lake Pluton, Canada: Lithos, v. 91, p. 19-34.

Shannon, R. D., 1976, Revised Effective Ionic-Radii and Systematic Studies of Interatomic Distances in Halides and Chalcogenides: Acta Crystallographica Section A, v. 32, no. Sep1, p. 751-767.

Sun, S. S., and McDonough, W. F., 1989, Chemical and isotopic systematics of oceanic basalts: implications for mantle composition and processes: Geological Society, London, Special Publications, v. 42, p. 313-345.

Tiepolo, M., Oberti, R., Zanetti, A., Vannucci, R., and Foley, S. F., 2007, Trace-element partitioning between amphibole and silicate melt: Amphiboles: Crystal Chemistry, Occurrence, and Health Issues, v. 67, p. 417-451.

Tiepolo, M., Vannucci, R., Bottazzi, P., Oberti, R., Zanetti, A., and Foley, S., 2000, Partitioning of rare earth elements, $\mathrm{Y}, \mathrm{Th}, \mathrm{U}$, and $\mathrm{Pb}$ between pargasite, kaersutite, and basanite to trachyte melts: Implications for percolated and veined mantle: Geochemistry Geophysics Geosystems, v. 1.

Tuttle, O. F., and Bowen, N. L., 1958, Origin of granite in the light of experimental studies in the system $\mathrm{NaAlSi}_{3} \mathrm{O}_{8}-\mathrm{KAlSi}_{3} \mathrm{O}_{8}-\mathrm{SiO}_{2}-\mathrm{H}_{2} \mathrm{O}$, Geological Society of America, Memoir 74, 146 p.: 
926 Vasyukova, O., and Williams-Jones, A. E., 2014, Fluoride-silicate melt immiscibility and its role in REE ore formation: Evidence from the Strange Lake rare metal deposit, Que'becLabrador, Canada: Geochimica et Cosmochimica Acta, v. 139, no. 2014, p. 110-130.

929 -, 2016, The evolution of immiscible silicate and fluoride melts: Implications for REE oregenesis: Geochimica et Cosmochimica Acta, v. 172, p. 205-224.

931 Vasyukova, O. V., Williams-Jones, A. E., and Blamey, N. J. F., 2016, Fluid evolution in the Geology, v. 444, p. 83-100. 
Fig. 1: A geological map of the Strange Lake pluton showing the distribution of the major lithological units. Locations of the samples used in this study are indicated.

Fig. 2: Thin section photomicrographs showing a) amphibole in hypersolvus granite (Arf), occupying interstices between alkali-feldspar (perthite) (Afs) and quartz (Qtz) (ppl view), b) amphibole in hypersolvus granite showing swapped margin texture with alkali-feldspar (ppl), c) interstitial amphibole in the northern hypersolvus granite that has been largely replaced by aenigmatite (red) (Aen) and astrophyllite (orange) (Ast) (xpl) and d) a Li-bearing amphibole (Lea) phenocryst in transsolvus granite that has been partly replaced by aegirine (Aeg) along its $944 \operatorname{rim}(\mathrm{ppl})$.

Fig. 3: Backscattered electron images of Strange Lake amphibole-group minerals showing a) arfvedsonite with one large and numerous small fluorite $(\mathrm{Fl})$ and fluorite-fluocerite solid solution (Fl-Flc) (brighter) inclusions (hypersolvus granite), b) amphibole interstitial to perthitic alkali feldspar and quartz (hypersolvus granite), replaced by fibrous astrophyllite along the rim, c) an euhedral Li-bearing alkali amphibole (ferro-ferri-fluoro-leakeite) crystal (transsolvus granite) containing numerous microcline $(\mathrm{Mc})$ and albite $(\mathrm{Ab})$ inclusions and, d) small subhedral amphibole crystals among K-feldspar (Ksp) and quartz crystals (enclave).

Fig. 4: Ternary diagrams showing a) the A-and B-site occupancy of the sodic-calcic to sodic amphibole-group minerals of the Strange Lake pluton (in apfu) (note that theoretically, endmember arfvedsonite can have any composition along the $\mathrm{Na}-\mathrm{K}$ tie-line), and b) the $\mathrm{C}$-site occupation of the amphibole-group minerals. The diagram (b) organizes the compositional data according to the valence state of the cations, where $\mathrm{R}^{+}={ }^{\mathrm{C}} \mathrm{Li}^{+}, \mathrm{R}^{2+}=\mathrm{Fe}^{2+}, \mathrm{Mn}^{2+}, \mathrm{Mg}^{2+}, \mathrm{Zn}^{2+}$ and 
$957 \mathrm{R}^{3+}=\mathrm{Fe}^{3+},{ }^{\mathrm{C}} \mathrm{Al}^{3+}$. The endmember compositions of katophorite (sodic-calcic), arfvedsonite and 958 leakeite (sodic) are indicated on the diagrams. In the legend "fgr" (southern hypersolvus granite) 959 refers to the fine-grained rocks of the unit, whereas "peg" stands for the oikiocrystic to 960 pegmatitic textured rocks.

961 Fig. 5: Binary diagrams showing major and minor element concentrations of amphibole in atoms 962 per formula unit (apfu), all as a function of $\mathrm{Al}$ concentration (X-axis). The decreasing $\mathrm{Al}$ content 963 monitors the differentiation of the magma.

964 Fig. 6: Binary diagrams showing the changing concentration (apfu) of selected elements as a 965 function of $\mathrm{Al}$ concentration (dashed arrows) from the cores to rims of amphibole phenocrysts in 966 the transsolvus granite.

967 Fig. 7: Chondrite-normalized REE- and trace element profiles of the Strange Lake amphibole968 group minerals displayed with the average bulk rock profiles of the respective units. a) REE- and b) trace element spider diagram for the southern hypersolvus granite; c) REE- and d) trace 970 element spider diagram for the northern hypersolvus granite; and e) REE- and f) trace element 971 spider diagram for the transsolvus granite and enclaves. The chondrite values are from Sun and 972 McDonough, 1989. Fig. 8: Chondrite-normalized REE-spider diagrams showing the average distribution of the 974 elements corresponding to the amphibole species identified in the Strange Lake pluton. The 975 chondrite values are from Sun and McDonough, 1989.

976 Fig. 9: Binary diagram showing the amphibole $\mathrm{Fe}^{2+} / \mathrm{Fe}^{3+}$ ratio as a function of the $\mathrm{Na} / \mathrm{Ca}$ ratio in 977 both, hypersolvus and transsolvus granite indicating a (low degree) coupled behavior of the 978 ratios in rocks with the same major phase paragenesis. 
Fig. 10: Bar diagram showing the (average) relative proportion of the anions occupying the Wsite for each granite unit.

Fig. 11: Binary diagram illustrating the positive correlation between $\mathrm{Fe}^{3+}$ and $\mathrm{Li}^{+}$in amphibole from the different granite facies. Linear trend lines and correlation coefficients have been added to distinguish amphibole in the hypersolvus granite from that in the transsolvus granite. Lithium concentrations are consistently lower in the hypersolvus granite than in the transsolvus granite.

Fig. 12: Binary diagrams showing the total REE concentration in amphibole of the different granite facies as a function of the concentration of selected major elements. Also shown are the corresponding trend lines and correlation coefficients $\left(\mathrm{R}^{2}\right)$.

Fig. 13: Diagram showing the ionic radii of the REE either in 6-fold (C-site) or 8-fold (B-site) coordination versus the apparent partition coefficient $\mathrm{D}_{\text {arf-bulk }}$ (median REE content of amphibole / REE content of the bulk rock, sample 204720), plotted with error bars (median absolute deviation). Also shown is a Lattice-Strain Theory fit through these data (solid line).

Fig. 14: Chart comparing the relative proportions of the bulk rock REE concentrations hosted by amphibole (average values) for each granite facies (see text for details). The chart for the southern hypersolvus granite only considers fine-grained samples.

Fig. 15: Cartoons showing the evolution of amphibole in the context of the textural development of a) hypersolvus and b) transsolvus granite, from liquidus to solidus stages and the subsolidus Na-alteration that affected the transsolvus granite. Crystallization temperature-, pressure- and oxygen fugacity ranges are given, and were taken from the studies of the Strange Lake pluton by Salvi and Williams-Jones (1992) and Vasyukova et al. (2016). The $f \mathrm{O}_{2}$ ranges are indicated in 
1000 respect to the iron oxide buffers, $\mathrm{MH}$ (magnetite-hematite), QFM (quartz-fayalite-magnetite) and 1001 QIF (quartz-iron-fayalite). 


\section{Tables}

1003 Table 1: Average (median) bulk rock major and trace element compositions of the unaltered

1004 granites from the center of the Strange Lake pluton $\left(*\right.$ fgr $=$ fine grained samples, ${ }^{+}$oik/peg $=$ 1005 oikocrystic and pegmatitic samples)

\begin{tabular}{|c|c|c|c|c|c|c|c|c|c|c|}
\hline \multirow{3}{*}{$\begin{array}{l}\text { Unit } \\
\text { Samples }\end{array}$} & \multicolumn{2}{|c|}{$\begin{array}{l}\text { Hypersolvus } \\
\text { granite S fgr* }\end{array}$} & \multicolumn{2}{|c|}{$\begin{array}{l}\text { Hypersolvus } \\
\text { granite S oik/peg }\end{array}$} & \multicolumn{2}{|c|}{$\begin{array}{l}\text { Hypersolvus } \\
\text { granite } \mathrm{N}\end{array}$} & \multicolumn{2}{|c|}{$\begin{array}{l}\text { Transsolvus } \\
\text { granite }\end{array}$} & \multicolumn{2}{|c|}{ Enclaves } \\
\hline & 7 & & 8 & & 12 & & 24 & & 12 & \\
\hline & & $+/-$ & & $+/-$ & & $+/-$ & & $+/-$ & & $+/-$ \\
\hline $\mathrm{SiO}_{2}$ wt. $\%$ & 69.04 & 0.89 & 70.57 & 0.56 & 70.68 & 0.36 & 71.28 & 0.53 & 69.36 & 0.60 \\
\hline $\mathrm{Al}_{2} \mathrm{O}_{3}$ & 11.88 & 0.26 & 10.57 & 0.17 & 11.74 & 0.21 & 10.27 & 0.39 & 11.97 & 0.25 \\
\hline $\mathrm{Fe}_{2} \mathrm{O}_{3}$ & 5.78 & 0.31 & 6.72 & 0.52 & 4.89 & 0.08 & 5.98 & 0.47 & 5.05 & 0.10 \\
\hline $\mathrm{MnO}$ & 0.10 & 0.01 & 0.11 & 0.01 & 0.10 & 0.01 & 0.12 & 0.01 & 0.09 & 0.02 \\
\hline $\mathrm{MgO}$ & 0.04 & 0.01 & 0.02 & 0.01 & 0.05 & 0.01 & 0.03 & 0.01 & 0.04 & 0.02 \\
\hline $\mathrm{CaO}$ & 0.73 & 0.19 & 0.37 & 0.11 & 0.57 & 0.03 & 0.45 & 0.18 & 0.83 & 0.15 \\
\hline $\mathrm{Na}_{2} \mathrm{O}$ & 4.92 & 0.17 & 5.11 & 0.05 & 5.09 & 0.10 & 5.08 & 0.35 & 3.60 & 0.98 \\
\hline $\mathrm{K}_{2} \mathrm{O}$ & 4.93 & 0.21 & 4.48 & 0.09 & 4.74 & 0.11 & 4.32 & 0.31 & 7.60 & 1.61 \\
\hline $\mathrm{TiO}_{2}$ & 0.28 & 0.03 & 0.21 & 0.03 & 0.27 & 0.01 & 0.21 & 0.05 & 0.15 & 0.04 \\
\hline $\mathrm{Nb}_{2} \mathrm{O}_{5}$ & 0.03 & 0.01 & 0.05 & 0.01 & 0.06 & 0.005 & 0.05 & 0.02 & 0.02 & 0.02 \\
\hline $\mathrm{P}_{2} \mathrm{O}_{5}$ & 0.02 & 0.00 & 0.02 & - & 0.02 & 0.01 & 0.01 & 0.01 & - & - \\
\hline $\mathrm{F}$ & 0.44 & 0.02 & 0.37 & 0.09 & 0.46 & 0.04 & 0.51 & 0.06 & 0.49 & 0.07 \\
\hline TREO & 0.17 & 0.03 & 0.19 & 0.02 & 0.24 & 0.03 & 0.48 & 0.06 & 0.25 & 0.03 \\
\hline LREO & 0.12 & 0.02 & 0.13 & 0.02 & 0.16 & 0.02 & 0.33 & 0.04 & 0.16 & 0.02 \\
\hline HREO+Y & 0.05 & 0.005 & 0.06 & 0.01 & 0.08 & 0.01 & 0.11 & 0.04 & 0.09 & 0.01 \\
\hline LOI & 0.72 & & 0.47 & & 0.70 & & 0.72 & & 0.83 & \\
\hline Total & 98.53 & & 99.19 & & 99.14 & & 99.20 & & 99.68 & \\
\hline Agp index & 1.13 & 0.02 & 1.23 & 0.02 & 1.15 & 0.03 & 1.27 & 0.03 & 1.17 & 0.02 \\
\hline $\mathrm{Be}(p p m)$ & 36 & 8 & 40 & 14 & 53 & 11 & 54 & 22 & 31 & 7 \\
\hline $\mathrm{Zn}$ & 285 & 40 & 545 & 30 & 465 & 60 & 585 & 90 & 465 & 145 \\
\hline $\mathrm{Ga}$ & 45 & 3 & 52 & 3 & 44 & 1 & 60 & 3 & 48 & 5 \\
\hline $\mathrm{Rb}$ & 417 & 23 & 436 & 31 & 522 & 47 & 672 & 99 & 925 & 241 \\
\hline $\mathrm{Sr}$ & 18 & 5 & 15 & 5 & 21 & 7 & 21 & 8 & 21 & 5 \\
\hline $\mathrm{Y}$ & 266 & 17 & 293 & 36 & 392 & 74 & 616 & 196 & 556 & 48 \\
\hline $\mathrm{Zr}$ & 2413 & 667 & 2504 & 469 & 3656 & 268 & 4984 & 1917 & 1488 & 1126 \\
\hline $\mathrm{Ba}$ & 76 & 13 & 43 & 8 & 85 & 18 & 43 & 15 & 58 & 14 \\
\hline $\mathrm{La}$ & 228 & 33 & 221 & 35 & 305 & 51 & 630 & 81 & 286 & 47 \\
\hline $\mathrm{Ce}$ & 464 & 73 & 485 & 72 & 629 & 79 & 1235 & 170 & 589 & 88 \\
\hline $\mathrm{Pr}$ & 56 & 14 & 60 & 7 & 73 & 10 & 149 & 20 & 74 & 10 \\
\hline $\mathrm{Nd}$ & 191 & 42 & 207 & 27 & 240 & 35 & 527 & 52 & 282 & 23 \\
\hline $\mathrm{Sm}$ & 39 & 10 & 51 & 6 & 49 & 6 & 115 & 16 & 68 & 5 \\
\hline $\mathrm{Eu}$ & 2 & 0.4 & 3 & 0.4 & 3 & 0.4 & 6 & 1 & 4 & 0.2 \\
\hline $\mathrm{Gd}$ & 33 & 5 & 44 & 7 & 45 & 7 & 100 & 18 & 66 & 7 \\
\hline $\mathrm{Tb}$ & 6 & 1 & 8 & 1 & 10 & 1 & 17 & 4 & 12 & 1 \\
\hline Dy & 44 & 7 & 53 & 8 & 69 & 12 & 103 & 29 & 72 & 10 \\
\hline Ho & 10 & 2 & 11 & 2 & 15 & 2 & 21 & 7 & 14 & 3 \\
\hline $\mathrm{Er}$ & 33 & 6 & 36 & 7 & 50 & 6 & 64 & 24 & 37 & 10 \\
\hline $\mathrm{Tm}$ & 5 & 1 & 6 & 1 & 8 & 1 & 9 & 4 & 5 & 2 \\
\hline $\mathrm{Yb}$ & 36 & 3 & 42 & 9 & 57 & 4 & 58 & 29 & 25 & 10 \\
\hline $\mathrm{Lu}$ & 6 & 0.4 & 7 & 1 & 9 & 1 & 8 & 4 & 4 & 1 \\
\hline
\end{tabular}




\begin{tabular}{lcccccccccc}
$\mathrm{Hf}$ & 69 & 12 & 67 & 12 & 97 & 15 & 136 & 47 & 42 & 31 \\
$\mathrm{Ta}$ & 14 & 1 & 20 & 4 & 28 & 4 & 25 & 13 & 7 & 5 \\
$\mathrm{~Pb}$ & 94 & 17 & 169 & 53 & 137 & 38 & 187 & 73 & 38 & 21 \\
$\mathrm{Th}$ & 54 & 9 & 69 & 20 & 88 & 15 & 84 & 40 & 23 & 17 \\
$\mathrm{U}$ & 10 & 3 & 14 & 3 & 19 & 2 & 17 & 8 & 4 & 3 \\
\hline
\end{tabular}

1006

Siegel K, Williams-Jones AE, van Hinsberg VJ (2017) The amphiboles of the REE-rich A-type peralkaline Strange Lake pluton fingerprints of magma evolution. Lithos 288:156-174. doi: 10.1016/j.lithos.2017.07.012. 
1007 Table 2: Average calculated formulae and cation assignments (in apfu) of amphibole group 1008 minerals, based on 24 oxygens. Ideal site occupation is noted in brackets. The rock units are: HS $1009 \mathrm{~S}$ fgr (hypersolvus granite south, fine grained), HS N (hypersolvus granite north), EN (enclaves), 1010 TS (transsolvus granite).

\begin{tabular}{|c|c|c|c|c|c|}
\hline Species & $\begin{array}{c}\text { Arfved } \\
\text { sonite }\end{array}$ & $\begin{array}{l}\text { Fluor- } \\
\text { arfveds } \\
\text { onite }\end{array}$ & $\begin{array}{c}\text { Ferro- } \\
\text { ferri- } \\
\text { leakeite }\end{array}$ & $\begin{array}{l}\text { Ferro- } \\
\text { ferri- } \\
\text { fluoro- } \\
\text { leakeite }\end{array}$ & $\begin{array}{l}\text { Ferro- } \\
\text { ferri- } \\
\text { kato- } \\
\text { phorite }\end{array}$ \\
\hline Unit & & $\begin{array}{c}\text { all } \\
\text { units }\end{array}$ & & $\begin{array}{c}\text { HS N, } \\
\text { TS }\end{array}$ & $\begin{array}{c}\text { HS S } \\
\text { fgr }\end{array}$ \\
\hline Analyses & $n=12$ & $n=56$ & $n=5$ & $n=70$ & $n=6$ \\
\hline \multicolumn{6}{|c|}{ Formula Assignments } \\
\hline $\mathrm{Si}$ & 7.64 & 7.83 & 7.64 & 7.74 & 7.53 \\
\hline $\mathrm{Al}$ & 0.23 & 0.10 & 0.11 & 0.07 & 0.36 \\
\hline $\mathrm{Ti}$ & 0.09 & 0.09 & 0.11 & 0.09 & 0.11 \\
\hline $\mathrm{Fe}^{3+}$ & 0.10 & 0.03 & 0.15 & 0.12 & - \\
\hline $\mathrm{T}(8)$ & 8.00 & 8.00 & 8.00 & 8.00 & 8.00 \\
\hline $\mathrm{Ti}$ & 0.09 & 0.06 & - & 0.03 & 0.10 \\
\hline $\mathrm{Zr}$ & 0.01 & 0.01 & 0.02 & 0.01 & - \\
\hline $\mathrm{Al}$ & 0.10 & 0.05 & - & - & - \\
\hline REE & 0.02 & 0.01 & 0.01 & - & 0.03 \\
\hline $\mathrm{Fe}^{3+}$ & 1.66 & 1.70 & 1.99 & 2.01 & 1.36 \\
\hline $\mathrm{Zn}$ & 0.08 & 0.04 & 0.11 & 0.05 & 0.06 \\
\hline $\mathrm{Mn}^{2+}$ & 0.09 & 0.10 & 0.09 & 0.08 & 0.10 \\
\hline $\mathrm{Fe}^{2+}$ & 2.62 & 2.49 & 1.96 & 2.00 & 3.02 \\
\hline $\mathrm{Mg}$ & 0.06 & 0.04 & 0.05 & 0.02 & 0.09 \\
\hline $\mathrm{Li}$ & 0.29 & 0.31 & 0.71 & 0.74 & 0.15 \\
\hline $\mathrm{C}(5)$ & 4.87 & 4.75 & 4.94 & 4.92 & 4.91 \\
\hline $\mathrm{Li}$ & - & - & 0.07 & 0.08 & - \\
\hline $\mathrm{Ca}$ & 0.23 & 0.10 & 0.09 & 0.03 & 0.57 \\
\hline $\mathrm{Na}$ & 1.77 & 1.90 & 1.87 & 1.95 & 1.43 \\
\hline B (2) & 2.00 & 2.00 & 2.00 & 2.00 & 2.00 \\
\hline $\mathrm{Na}$ & 0.79 & 0.89 & 0.87 & 0.86 & 0.69 \\
\hline $\mathrm{K}$ & 0.28 & 0.31 & 0.31 & 0.33 & 0.26 \\
\hline $\mathrm{A}(0-1)$ & 1.07 & 1.20 & 1.18 & 1.19 & 0.95 \\
\hline $\mathrm{OH}$ & 1.05 & 0.70 & 0.93 & 0.61 & 1.14 \\
\hline $\mathrm{F}$ & 0.72 & 1.07 & 0.85 & 1.20 & 0.44 \\
\hline $\mathrm{Cl}$ & 0.01 & - & - & - & 0.01 \\
\hline $\mathrm{O}$ & 0.23 & 0.22 & 0.21 & 0.19 & 0.41 \\
\hline W (2) & 2.00 & 2.00 & 2.00 & 2.00 & 2.00 \\
\hline
\end{tabular}

1011 
1012 Table 3: List of amphibole and titanium bearing minerals identified in the unaltered Strange Lake

1013 granites with their endmember structural formulae

\begin{tabular}{ll}
\hline Mineral name & Formula \\
\hline $\begin{array}{l}\text { Amphibole-group minerals } \\
\text { (Fluoro)-arfvedsonite }\end{array}$ & \\
$\begin{array}{l}\text { Ferro-ferri-(fluoro)-katophorite } \\
\text { Ferro-ferri-(fluoro)-leakeite }\end{array}$ & $\mathrm{NaNa}\left(\mathrm{Fe}^{2+}{ }_{4} \mathrm{Fe}^{3+}\right) \mathrm{Si}_{8} \mathrm{O}_{22}(\mathrm{OH}, \mathrm{F})_{2}$ \\
& $\mathrm{NaNa}_{2}\left(\mathrm{Fe}^{2+}\right)_{2}\left(\mathrm{Fe}^{3+}\right)_{2} \mathrm{LiSi}_{8} \mathrm{~S}_{22}(\mathrm{OH}, \mathrm{F})_{2}$ \\
Clinopyroxenes & \\
Aegirine & $\mathrm{NaFe}^{3+} \mathrm{Si}_{2} \mathrm{O}_{6}$ \\
& \\
Titano-silicates and Ti-oxide mineral \\
Aenigmatite \\
$\begin{array}{l}\text { Astrophyllite } \\
\text { Narsarsukite } \\
\text { Titanite }\end{array}$ & $\mathrm{Na}_{2} \mathrm{Fe}^{2+}{ }_{5} \mathrm{TiSi}_{6} \mathrm{O}_{20}$ \\
Ilmenite & $\left(\mathrm{K}, \mathrm{Na}_{3}\left(\mathrm{Fe}^{2+}\right)_{7} \mathrm{Ti}_{2} \mathrm{Si}_{8} \mathrm{O}_{26}(\mathrm{OH})_{4}\right.$ \\
\hline
\end{tabular}

1014 
1015 Table 4: Average (median) major and trace element compositions with median absolute 1016 deviation (+/-) of the amphibole group minerals from the unaltered part of the Strange Lake 1017 pluton $\left(* \mathrm{fgr}=\right.$ fine grained samples, ${ }^{+}$oik/peg $=$oikocrystic and pegmatitic samples $)$

\begin{tabular}{|c|c|c|c|c|c|c|c|c|c|c|}
\hline \multirow{2}{*}{$\begin{array}{l}\text { Unit } \\
\text { Analyses }\end{array}$} & \multicolumn{2}{|c|}{$\begin{array}{l}\text { Hypersolvus } \\
\text { granite S fgr* }\end{array}$} & \multicolumn{2}{|c|}{$\begin{array}{l}\text { Hypersolvus } \\
\text { granite S oik/peg }\end{array}$} & \multicolumn{2}{|c|}{$\begin{array}{l}\text { Hypersolvus } \\
\text { granite N }\end{array}$} & \multicolumn{2}{|l|}{ Enclaves } & \multicolumn{2}{|c|}{$\begin{array}{l}\text { Transsolvus } \\
\text { granite }\end{array}$} \\
\hline & $n=13$ & & $n=19$ & & $n=39$ & & $n=9$ & & $n=72$ & \\
\hline & & $+/-$ & & $+/-$ & & $+/-$ & & $+/-$ & & $+/-$ \\
\hline $\mathrm{SiO}_{2}$ wt. $\%$ & 48.29 & 0.51 & 49.97 & 0.80 & 50.71 & 0.19 & 50.71 & 0.93 & 51.02 & 0.52 \\
\hline $\mathrm{Al}_{2} \mathrm{O}_{3}$ & 1.47 & 0.30 & 0.99 & 0.15 & 0.50 & 0.08 & 0.36 & 0.01 & 0.34 & 0.05 \\
\hline $\mathrm{TiO}_{2}$ & 1.45 & 0.30 & 0.84 & 0.12 & 1.09 & 0.14 & 0.92 & 0.08 & 0.71 & 0.09 \\
\hline $\mathrm{FeO}$ & 33.67 & 0.42 & 33.80 & 0.41 & 32.06 & 0.27 & 31.78 & 0.22 & 32.47 & 0.38 \\
\hline $\mathrm{MgO}$ & 0.72 & 0.05 & 0.64 & 0.05 & 0.85 & 0.03 & 0.71 & 0.08 & 0.56 & 0.04 \\
\hline $\mathrm{MnO}$ & 0.34 & 0.07 & 0.10 & 0.08 & 0.22 & 0.03 & 0.09 & 0.03 & 0.08 & 0.03 \\
\hline $\mathrm{ZnO}$ & 0.62 & 0.16 & 0.24 & 0.05 & 0.45 & 0.04 & 0.60 & 0.11 & 0.30 & 0.05 \\
\hline $\mathrm{ZrO}_{2}$ & 0.04 & 0.02 & 0.06 & 0.03 & 0.17 & 0.04 & 0.13 & 0.03 & 0.11 & 0.03 \\
\hline $\mathrm{Nb}_{2} \mathrm{O}_{5}$ & 0.07 & 0.02 & 0.02 & 0.01 & 0.02 & 0.02 & 0.02 & 0.01 & 0.01 & 0.004 \\
\hline $\mathrm{Na}_{2} \mathrm{O}$ & 7.25 & 0.54 & 9.18 & 0.20 & 9.36 & 0.09 & 9.34 & 0.19 & 9.57 & 0.13 \\
\hline $\mathrm{K}_{2} \mathrm{O}$ & 1.27 & 0.15 & 1.28 & 0.12 & 1.59 & 0.11 & 1.73 & 0.09 & 1.65 & 0.09 \\
\hline $\mathrm{CaO}$ & 2.79 & 0.69 & 1.11 & 0.50 & 0.47 & 0.08 & 0.13 & 0.05 & 0.13 & 0.03 \\
\hline $\mathrm{F}$ & 1.29 & 0.31 & 1.97 & 0.27 & 2.08 & 0.12 & 2.05 & 0.18 & 2.56 & 0.15 \\
\hline $\mathrm{Cl}$ & 0.03 & 0.01 & 0.02 & 0.01 & 0.01 & 0.01 & - & - & 0.01 & 0.005 \\
\hline Total & 99.18 & & 100.5 & & 99.87 & & 98.84 & & 99.93 & \\
\hline $\mathrm{Li}(p p m)$ & 1613 & 772 & 1450 & 615 & 3099 & 549 & 4802 & 931 & 5775 & 1260 \\
\hline $\mathrm{Rb}$ & 58.8 & 17.8 & 20.9 & 6.3 & 61.8 & 9.4 & 88.7 & 15.5 & 84.3 & 18.6 \\
\hline $\mathrm{Sr}$ & 23.3 & 6.8 & 8.5 & 3.0 & 11.7 & 3.7 & 4.0 & 1.4 & 1.4 & 0.5 \\
\hline $\mathrm{Y}$ & 471 & 145 & 70.9 & 26.0 & 107 & 27 & 92.0 & 32.0 & 27.7 & 5.5 \\
\hline $\mathrm{Zr}$ & 1208 & 653 & 647 & 124 & 2648 & 450 & 2073 & 234 & 1356 & 339 \\
\hline $\mathrm{Sn}$ & 160 & 80.3 & 21.3 & 8.9 & 156 & 49 & 90.1 & 36.2 & 137 & 41 \\
\hline $\mathrm{La}$ & 96.0 & 11.2 & 31.9 & 9.5 & 32.4 & 5.9 & 24.1 & 8.5 & 2.8 & 1.2 \\
\hline $\mathrm{Ce}$ & 282 & 24 & 91.6 & 14.7 & 85.9 & 22.6 & 45.3 & 9.7 & 6.6 & 2.8 \\
\hline $\operatorname{Pr}$ & 44.4 & 4.9 & 13.5 & 2.8 & 13.7 & 4.3 & 6.9 & 1.6 & 1.0 & 0.4 \\
\hline $\mathrm{Nd}$ & 218 & 25 & 60.1 & 15.7 & 62.3 & 20.5 & 32.5 & 8.0 & 4.7 & 2.2 \\
\hline $\mathrm{Sm}$ & 59.7 & 7.3 & 13.8 & 2.7 & 11.6 & 4.5 & 6.2 & 1.3 & 0.91 & 0.47 \\
\hline $\mathrm{Eu}$ & 4.0 & 0.3 & 0.85 & 0.22 & 0.68 & 0.30 & 0.37 & 0.17 & 0.05 & 0.02 \\
\hline Gd & 50.0 & 5.8 & 9.6 & 2.0 & 7.6 & 3.1 & 9.3 & 3.9 & 0.67 & 0.33 \\
\hline $\mathrm{Tb}$ & 10.6 & 1.5 & 1.7 & 0.5 & 1.6 & 0.6 & 1.7 & 0.7 & 0.21 & 0.08 \\
\hline Dy & 71.7 & 13.8 & 12.4 & 2.3 & 18.3 & 5.7 & 11.4 & 3.0 & 2.6 & 0.6 \\
\hline Ho & 17.1 & 3.7 & 3.1 & 0.5 & 7.7 & 1.8 & 3.2 & 0.9 & 1.2 & 0.3 \\
\hline $\mathrm{Er}$ & 69.7 & 21.2 & 15.1 & 2.9 & 48.5 & 12.3 & 14.9 & 1.2 & 8.1 & 1.4 \\
\hline $\mathrm{Tm}$ & 14.2 & 4.4 & 4.3 & 1.0 & 17.5 & 4.8 & 4.6 & 0.8 & 2.7 & 0.5 \\
\hline $\mathrm{Yb}$ & 144 & 52 & 53.1 & 11.8 & 215 & 53 & 52.4 & 5.7 & 35.9 & 6.3 \\
\hline $\mathrm{Lu}$ & 29.5 & 11.6 & 11.7 & 2.6 & 50.1 & 11.5 & 12.8 & 3.1 & 8.6 & 1.9 \\
\hline $\mathrm{Hf}$ & 60.3 & 35.8 & 27.5 & 7.0 & 130 & 25 & 85.0 & 20.6 & 63.6 & 17.6 \\
\hline $\mathrm{Ta}$ & 9.0 & 1.7 & 2.2 & 0.4 & 2.9 & 0.8 & 1.9 & 0.6 & 1.1 & 0.3 \\
\hline $\mathrm{Pb}$ & 77.9 & 8.0 & 8.9 & 5.1 & 34.5 & 10.5 & 10.7 & 4.6 & 5.8 & 1.7 \\
\hline $\mathrm{Nb}$ & 468 & 116 & 124 & 51 & 214 & 34 & 109 & 20 & 92.4 & 13.8 \\
\hline $\mathrm{Ba}$ & 10.5 & 6.3 & 3.4 & 2.5 & 6.0 & 2.4 & 1.9 & 0.9 & 0.43 & 0.26 \\
\hline Th & 1.7 & 1.4 & 0.75 & 0.66 & 0.51 & 0.47 & 2.9 & 2.5 & 0.02 & 0.02 \\
\hline U & 0.13 & 0.10 & 0.13 & 0.11 & 0.03 & 0.03 & 0.16 & 0.15 & 0.01 & 0.01 \\
\hline
\end{tabular}




\begin{tabular}{lllllllllll}
\hline TREE+Y & 1634 & 297 & 395 & 91 & 708 & 174 & 389 & 117 & 110 & 19
\end{tabular}

Siegel K, Williams-Jones AE, van Hinsberg VJ (2017) The amphiboles of the REE-rich A-type peralkaline Strange Lake pluton fingerprints of magma evolution. Lithos 288:156-174. doi: 10.1016/j.lithos.2017.07.012. 
1019 Table 5: Average (median) core and rim compositions (in apfu) with median absolute deviation 1020 (+/-) of selected phenocrysts from the transsolvus granite

\begin{tabular}{|c|c|c|c|c|}
\hline \multirow{2}{*}{$\begin{array}{l}\text { Location } \\
\text { Analyses }\end{array}$} & \multirow{2}{*}{$\begin{array}{l}\text { Core } \\
n=24\end{array}$} & \multicolumn{3}{|c|}{ Rim } \\
\hline & & & $n=7$ & \\
\hline & & $+/-$ & & $+/-$ \\
\hline${ }^{\mathrm{T}} \mathrm{Si}(a p f u)$ & 7.906 & 0.102 & 7.716 & 0.039 \\
\hline${ }^{\mathrm{T}} \mathrm{Al}$ & 0.059 & 0.006 & 0.059 & 0.003 \\
\hline${ }^{\mathrm{T}} \mathrm{Ti}$ & 0.072 & 0.010 & 0.083 & 0.008 \\
\hline${ }^{\mathrm{T}} \mathrm{Fe}^{3+}$ & 0.143 & 0.030 & 0.135 & 0.025 \\
\hline${ }^{\mathrm{C}} \mathrm{Ti}$ & 0.084 & 0.016 & 0.001 & - \\
\hline${ }^{\mathrm{C}} \mathrm{Zr}$ & 0.008 & 0.003 & 0.008 & 0.002 \\
\hline${ }^{\mathrm{C}} \mathrm{Al}$ & 0.052 & 0.019 & - & - \\
\hline${ }^{\mathrm{C}} \mathrm{REE}$ & 0.002 & 0.001 & 0.002 & - \\
\hline${ }^{\mathrm{C}} \mathrm{Fe}^{3+}$ & 1.763 & 0.215 & 2.022 & 0.007 \\
\hline${ }^{\mathrm{C}} \mathrm{Zn}$ & 0.034 & 0.006 & 0.072 & 0.015 \\
\hline${ }^{\mathrm{C}} \mathrm{Mn}^{2+}$ & 0.072 & 0.004 & 0.081 & 0.007 \\
\hline${ }^{\mathrm{C}} \mathrm{Fe}^{2+}$ & 2.441 & 0.321 & 1.952 & 0.058 \\
\hline${ }^{\mathrm{C}} \mathrm{Mg}$ & 0.026 & 0.006 & 0.014 & 0.001 \\
\hline $\mathrm{C}_{\mathrm{Li}}{ }^{\circ}$ & 0.407 & 0.232 & 0.825 & 0.044 \\
\hline${ }^{\mathrm{B}} \mathrm{Li}$ & 0.051 & 0.024 & 0.066 & 0.024 \\
\hline${ }^{\mathrm{B}} \mathrm{Ca}$ & 0.024 & 0.006 & 0.019 & 0.005 \\
\hline${ }^{\mathrm{B}} \mathrm{Na}$ & 1.973 & 0.009 & 1.964 & 0.017 \\
\hline${ }^{\mathrm{A}} \mathrm{Na}$ & 0.867 & 0.042 & 0.838 & 0.037 \\
\hline${ }^{\mathrm{A}} \mathrm{K}$ & 0.317 & 0.011 & 0.347 & 0.050 \\
\hline${ }^{\mathrm{w}} \mathrm{F}$ & 1.205 & 0.057 & 1.027 & 0.122 \\
\hline total $\mathrm{Ti}$ & 0.156 & 0.026 & 0.083 & 0.008 \\
\hline total $\mathrm{Al}$ & 0.111 & 0.025 & 0.059 & 0.003 \\
\hline total $\mathrm{Fe}^{3+}$ & 0.074 & 0.011 & 2.164 & 0.046 \\
\hline total $\mathrm{Na}$ & 1.906 & 0.245 & 2.769 & 0.040 \\
\hline total $\mathrm{Li}$ & 8.034 & 0.006 & 0.860 & 0.071 \\
\hline total $\mathrm{Fe}$ & 0.156 & 0.020 & 0.825 & 0.044 \\
\hline $\mathrm{Fe}^{2+} / \mathrm{Fe}^{3+}$ & 2.449 & 0.324 & 2.134 & 0.040 \\
\hline
\end{tabular}

1021 
1022 Table 6: Apparent melt-arfvedsonite partition coefficients ( $\left.\mathrm{D}_{\text {arf-bulk}}\right)$, ionic radius ' $\mathrm{r}$ ' in 6- and 8-

1023 fold coordination, ideal radius (r) for each element and median absolute deviation (MAD)

\begin{tabular}{lccccc}
\hline & $\mathrm{D}_{\text {arf-bulk }}$ & $\mathrm{r}_{\text {6-fold }}$ & $\mathrm{r}_{\text {8-fold }}$ & $\mathrm{r}$ & $\mathrm{MAD}^{*}$ \\
\hline $\mathrm{La}$ & 0.006 & 1.03 & 1.16 & 1.2 & 0.005 \\
$\mathrm{Ce}$ & 0.005 & 1.01 & 1.14 & 1.1 & 0.003 \\
$\mathrm{Pr}$ & 0.005 & 0.99 & 1.13 & 1.1 & 0.003 \\
$\mathrm{Nd}$ & 0.008 & 0.98 & 1.11 & 1.1 & 0.004 \\
$\mathrm{Sm}$ & 0.006 & 0.96 & 1.08 & 1.1 & 0.002 \\
$\mathrm{Eu}$ & 0.006 & 0.95 & 1.07 & 1.1 & 0.004 \\
$\mathrm{Gd}$ & 0.006 & 0.94 & 1.05 & 0.9 & 0.003 \\
$\mathrm{~Tb}$ & 0.014 & 0.92 & 1.04 & 0.9 & 0.002 \\
$\mathrm{Dy}$ & 0.027 & 0.91 & 1.03 & 0.9 & 0.005 \\
$\mathrm{Ho}$ & 0.075 & 0.90 & 1.02 & 0.9 & 0.011 \\
$\mathrm{Er}$ & 0.201 & 0.89 & 1.00 & 0.9 & 0.016 \\
$\mathrm{Tm}$ & 0.657 & 0.88 & 0.99 & 0.9 & 0.053 \\
$\mathrm{Yb}$ & 1.664 & 0.87 & 0.99 & 0.9 & 0.165 \\
$\mathrm{Lu}$ & 3.261 & 0.86 & 0.98 & 0.9 & 0.321 \\
$\mathrm{Y}$ & 0.043 & 0.90 & 1.02 & 0.9 & 0.006 \\
\hline
\end{tabular}

1024

1025 "The Median Absolute Deviation (MAD) is reported (plotted as error bars in Fig. 14) instead of the standard deviation, as the 1026 median amphibole concentration was used instead of the mean concentration. 
1028 Appendix A: Standards, counting time and detection limits used for electron microprobe 1029 analyses (EMPA) of the amphibole group minerals

\begin{tabular}{llcc}
\hline Element & Standard & $\begin{array}{c}\text { Counting } \\
\text { time (s) }\end{array}$ & $\begin{array}{c}\text { Detection } \\
\text { limit (ppm) }\end{array}$ \\
\hline $\mathrm{Na}$ & Albite & 20 & 267 \\
$\mathrm{Fe}$ & Hematite & 20 & 264 \\
$\mathrm{Mn}$ & Spessartine & 20 & 413 \\
$\mathrm{Ti}$ & Rutile & 20 & 370 \\
$\mathrm{Zr}$ & Zircon & 20 & 653 \\
$\mathrm{Si}$ & Diopside & 20 & 363 \\
$\mathrm{Ca}$ & Diopside & 20 & 243 \\
$\mathrm{Mg}$ & Diopside & 20 & 266 \\
$\mathrm{Al}$ & Orthoclase & 20 & 216 \\
$\mathrm{~K}$ & Orthoclase & 20 & 205 \\
$\mathrm{Cl}$ & Vanadinite & 20 & 218 \\
$\mathrm{~F}$ & Fluorite & 100 & 1501 \\
$\mathrm{Zn}$ & Willemite & 20 & 427 \\
\hline
\end{tabular}

1030

1031 Detection limits and standard deviations ( $2 \boldsymbol{\sigma})$ represent average detection limits calculated from repeated analyses of standards 1032 during the analytical runs. 


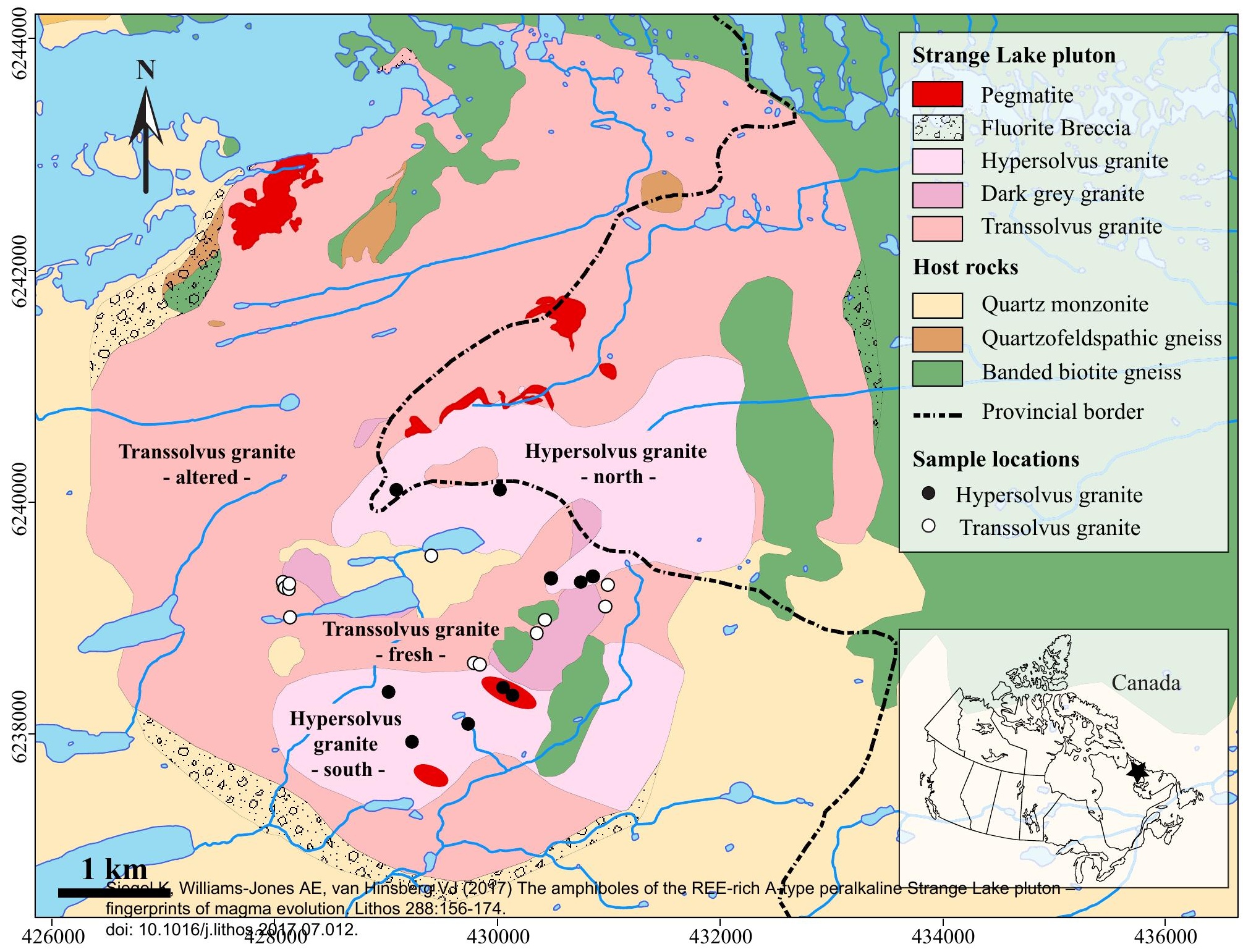



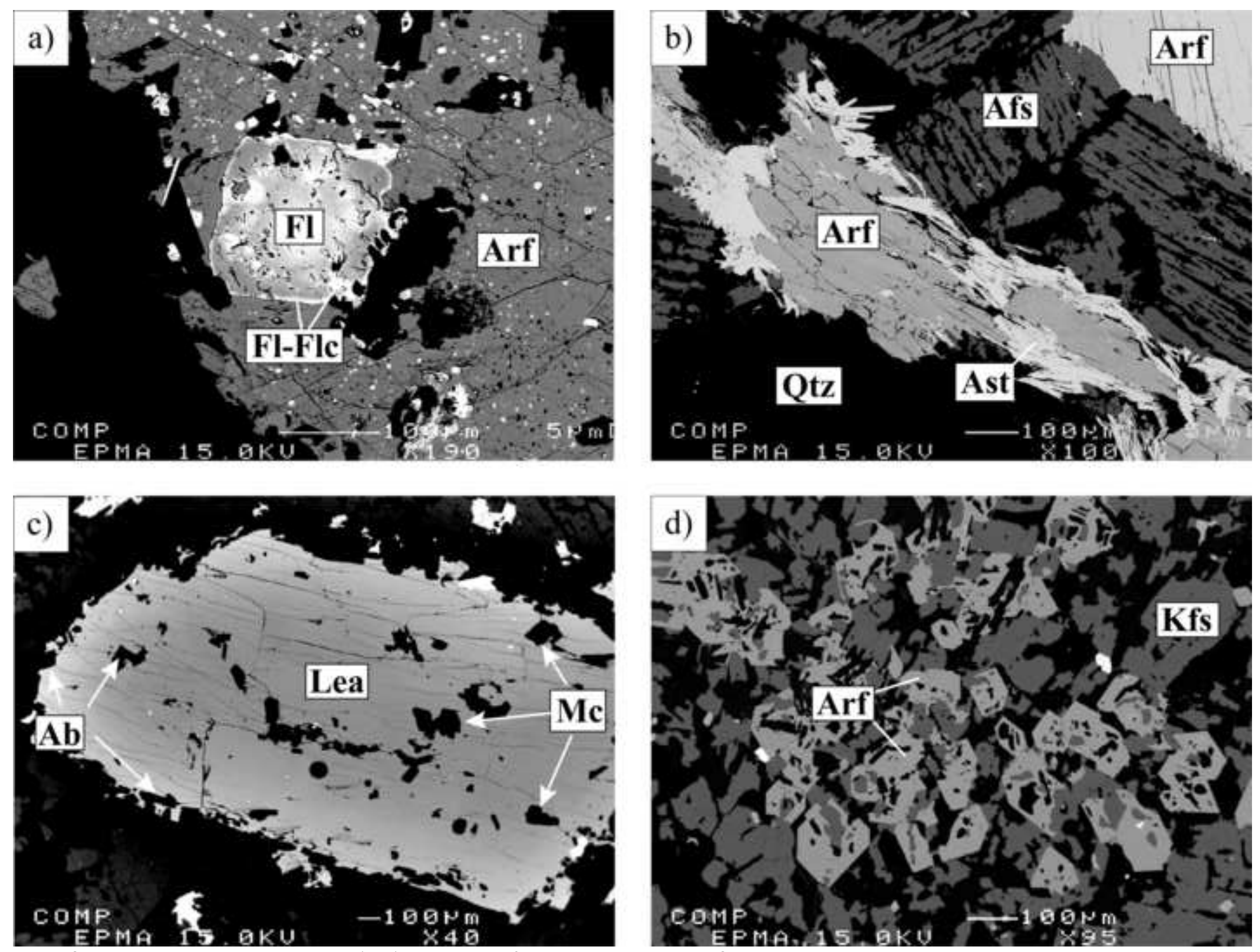

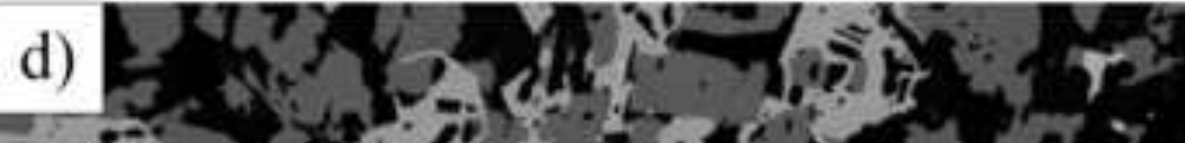
$-v i$ a

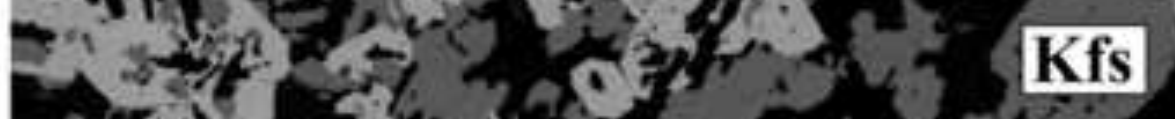

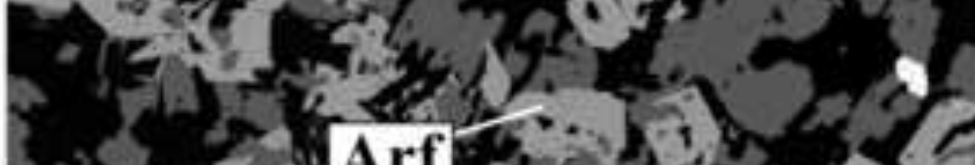
a.

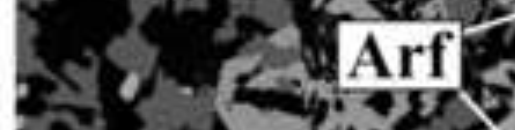
ald a. Siegel K, Williams-Jones AE, van Hinsberg VJ (2017) The amphiboles of the REE-rich A-type peralkaline Strange Lake pluton fingerprints of magma evolution. Lithos 288:156-174. 
Figure 4

a)

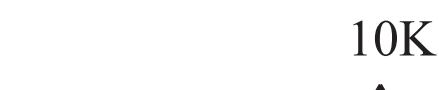

b)

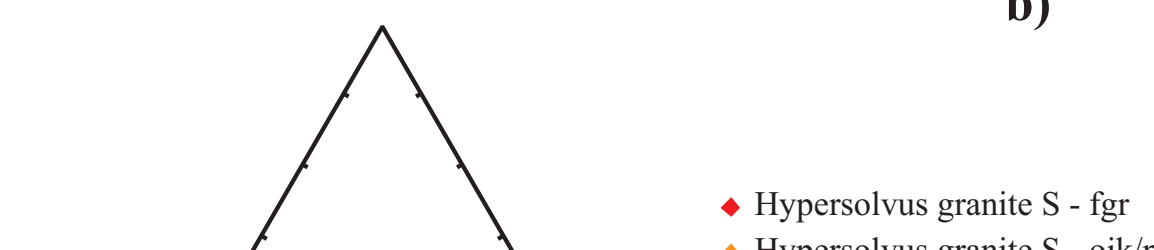

- Hypersolvus granite S - oik/peg

- Hypersolvus granite $\mathrm{N}$

- Transsolvus granite

- Enclaves

\section{A} $\mathrm{Na}$ $\mathrm{a}$

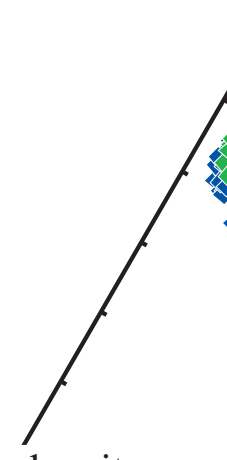

dsonit

ite $K, W i l a m s-J O n e s A E, v a n$ Hnsberg Kat

$\checkmark$ attol 288:156-174. doi: $10.1016 /$ j.lithos.2017.07.012.

288:156-174.

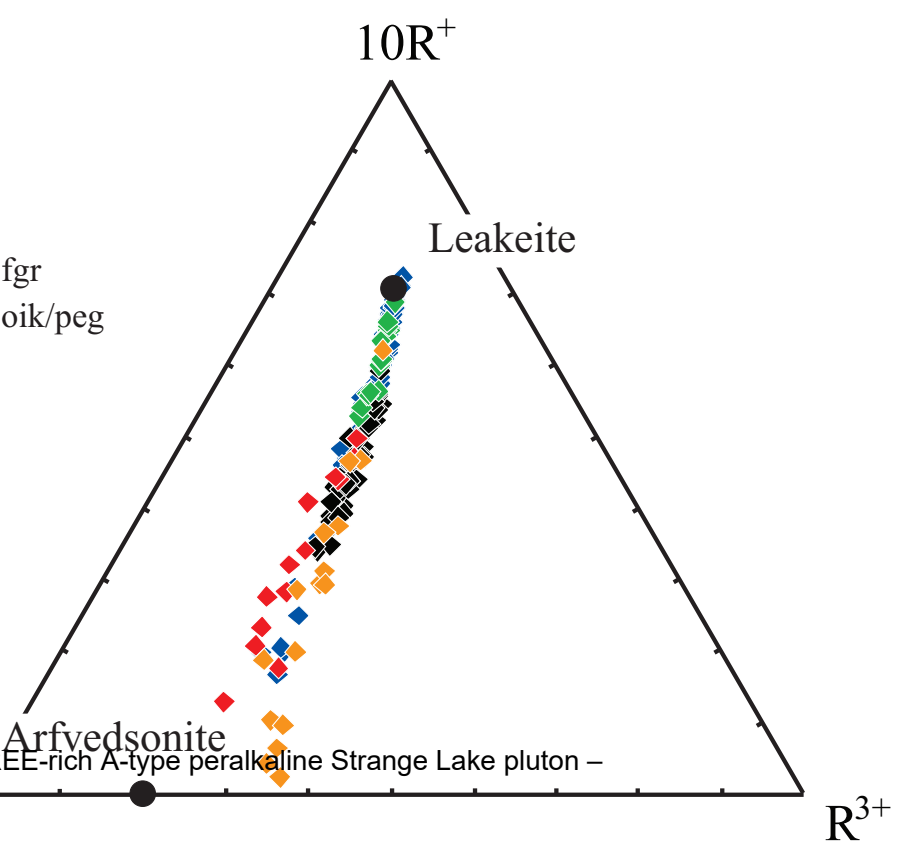



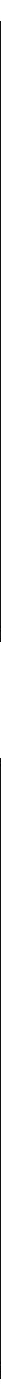

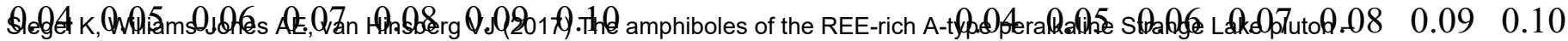

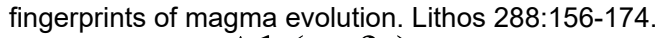
doi: 10.1016/j.lithoA40(apsfû̀).

Al (apfu) 
Hypersolvus granite south -

fine grained oikocrystic / pegmatitic

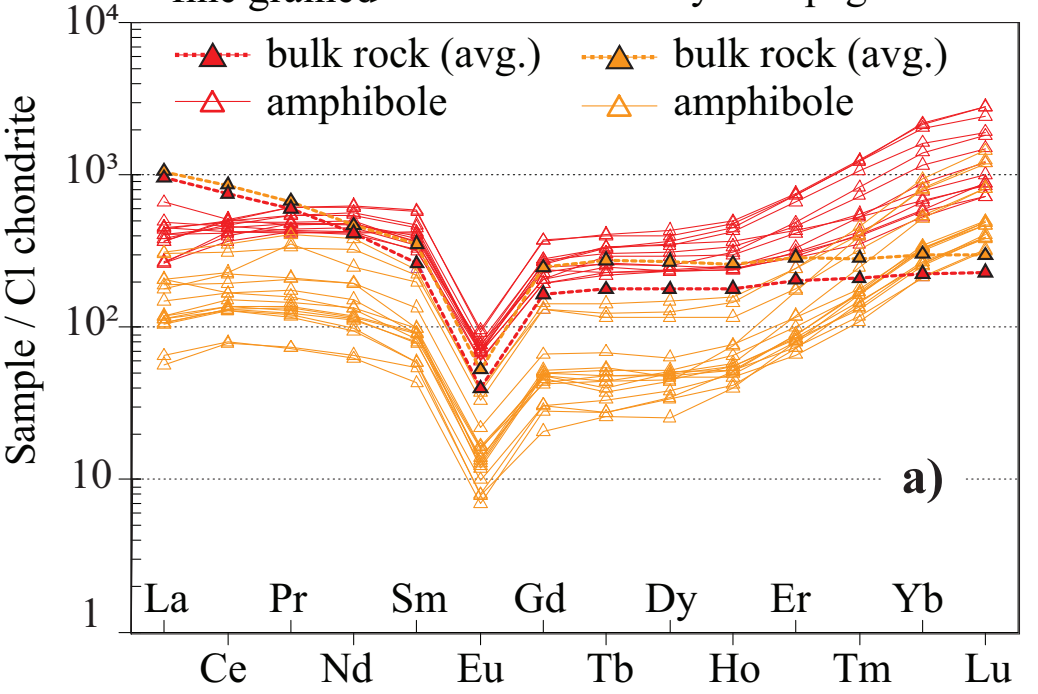

Hypersolvus granite north

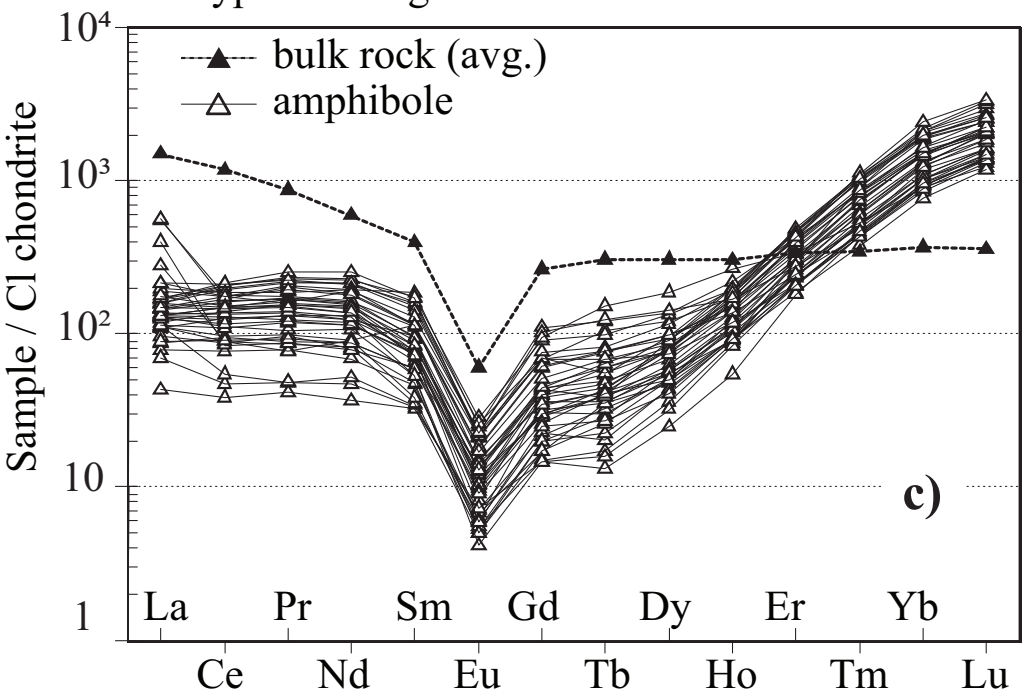

Transsolvus granite Enclaves

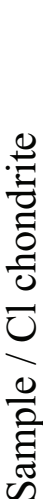

$10^{4}$

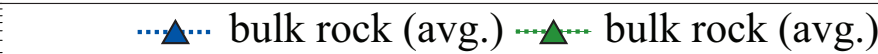

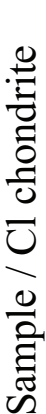

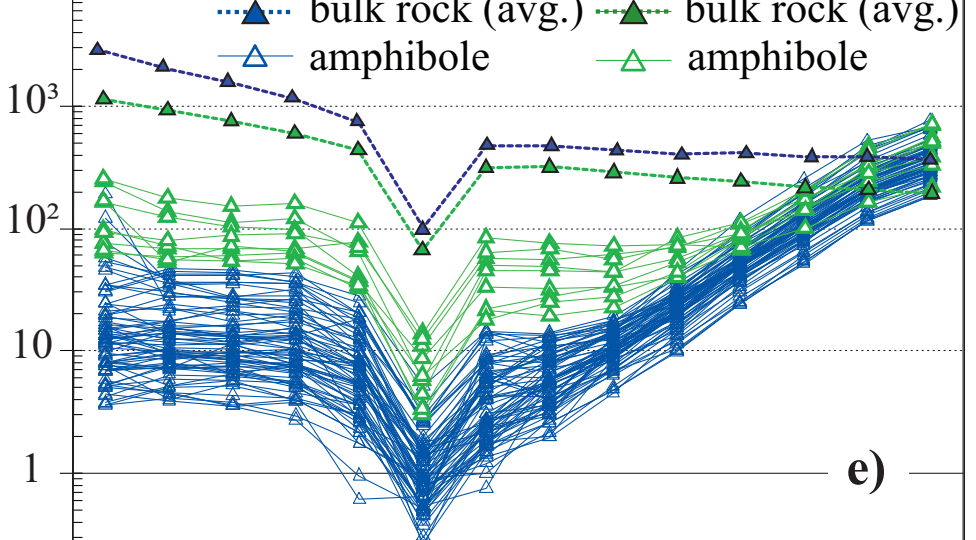

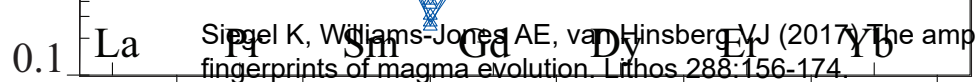

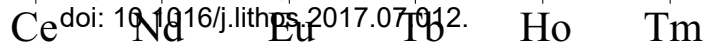
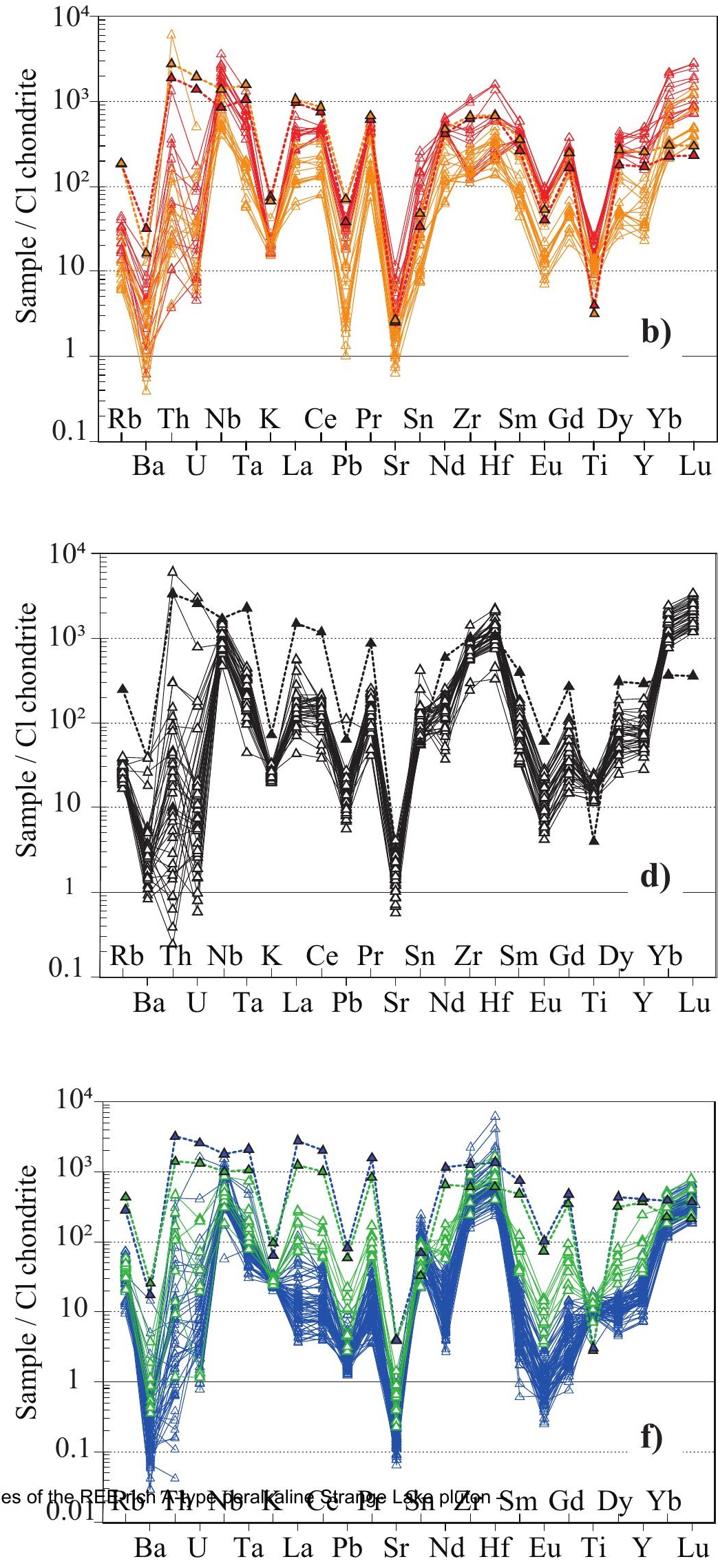


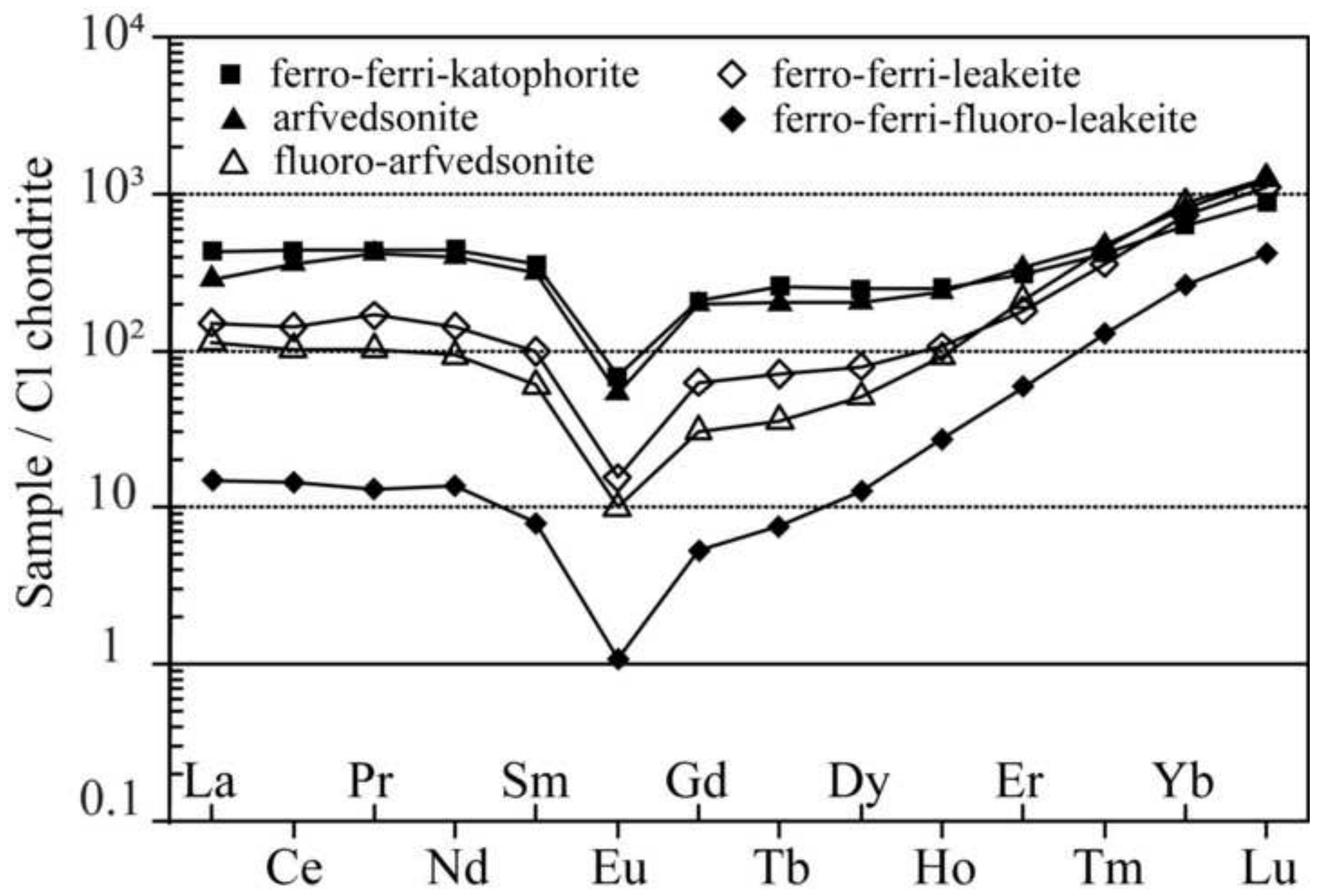

Siegel K, Williams-Jones AE, van Hinsberg VJ (2017) The amphiboles of the REE-rich A-type peralkaline Strange Lake pluton fingerprints of magma evolution. Lithos 288:156-174. doi: 10.1016/j.lithos.2017.07.012. 
Figure 9

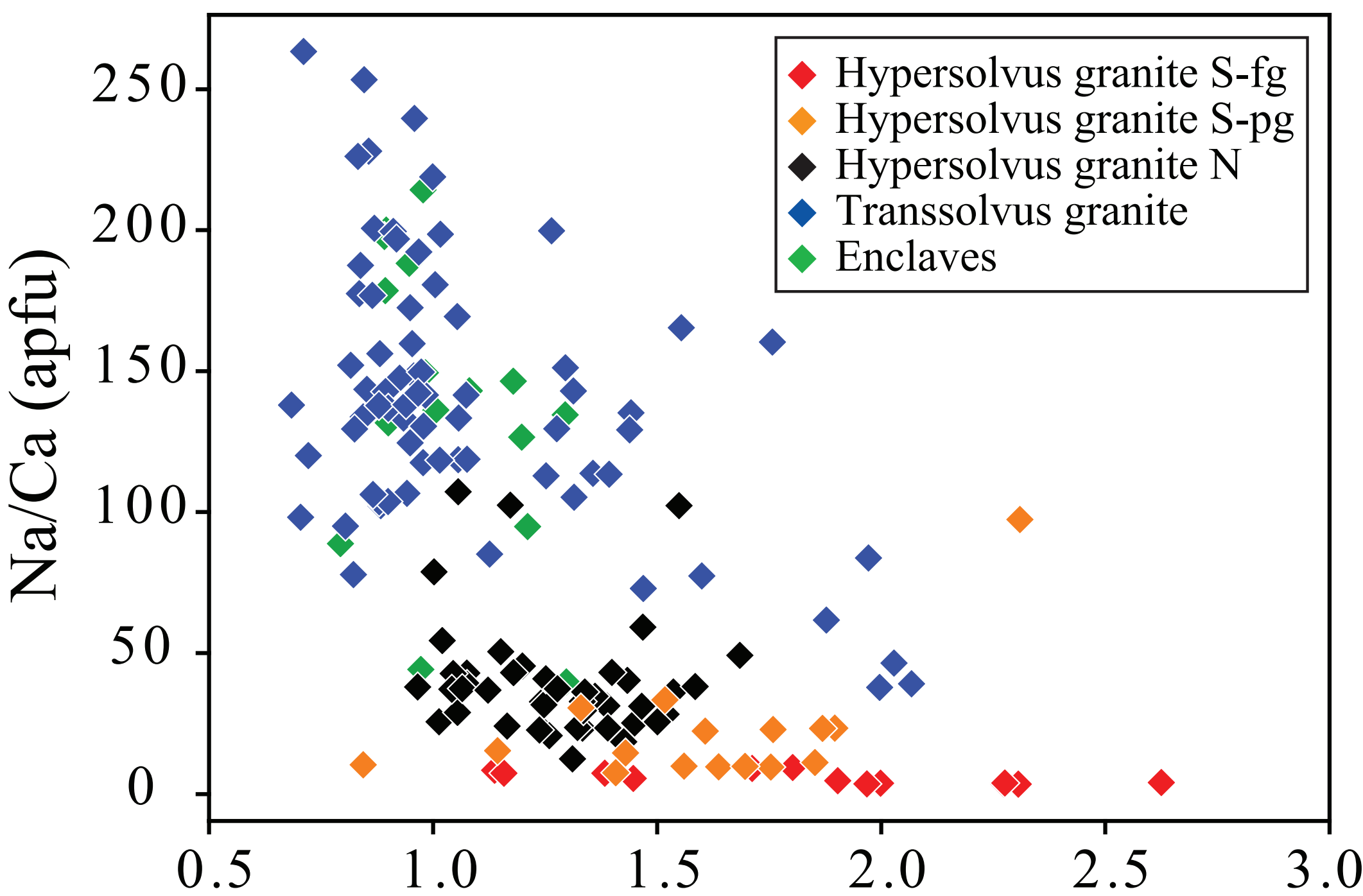

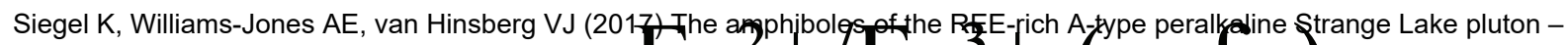

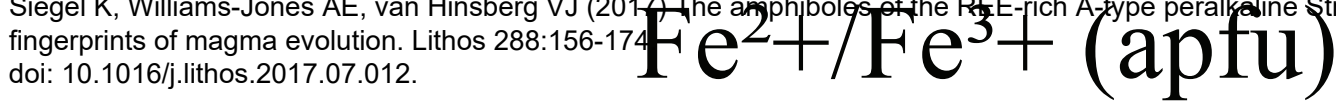




\section{$\mathrm{OH}$}

$\mathrm{F}+\mathrm{Cl}$

\section{Hypersolvus granite South}

\section{$\begin{array}{ll}1.05 \text { (apfu) } & 0.62\end{array}$}

\section{Hypersolvus granite North}

\subsection{3}

\section{Transsolvus granite}

\subsection{0}

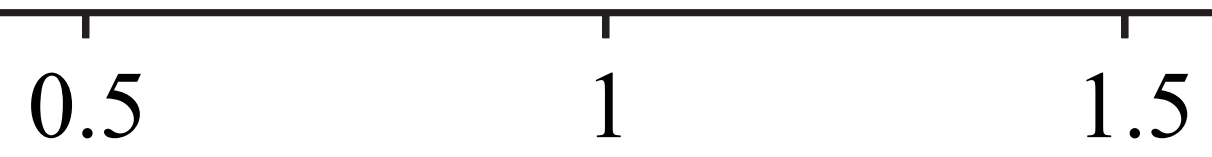

1.5

2

Siegel K, Williams-Jones AE, van Hinsberg VJ (2017) Th $\bar{q}$ amphiboles of the REE-rich A-trpe perłalkaline Strange Lake pluton fingerprints of magma evolution. Lithos 288:156-174 doi: 10.1016/j.lithos.2017.07.012. 


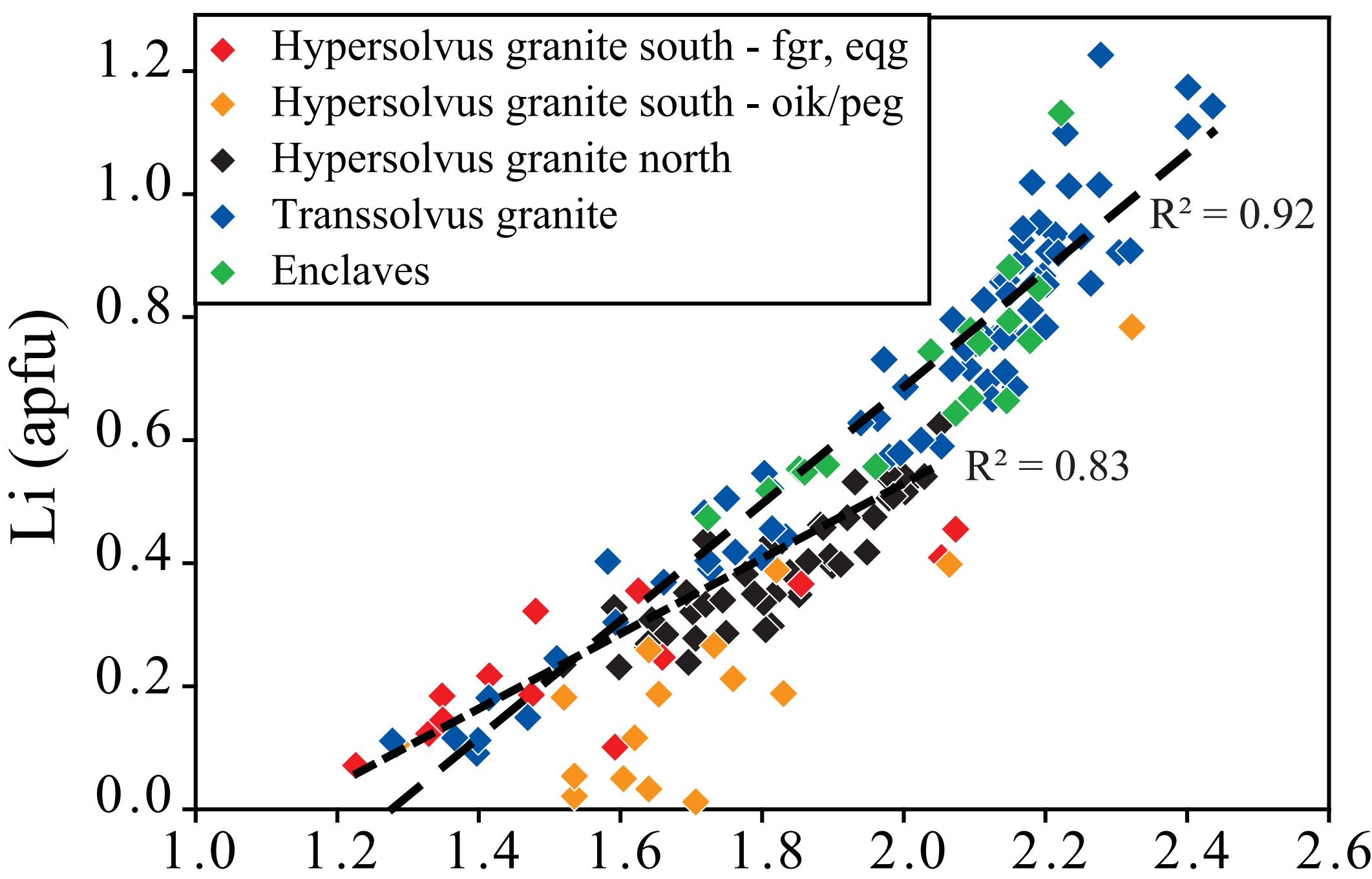

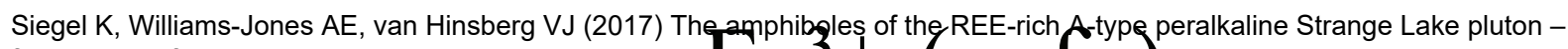

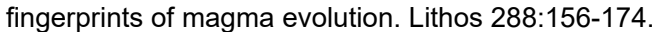
doi: 10.1016/j.lithos.2017.07.012.

\section{$\mathrm{Fe}^{-1}+(\mathrm{apflu})$}


Click here to download high resolution image

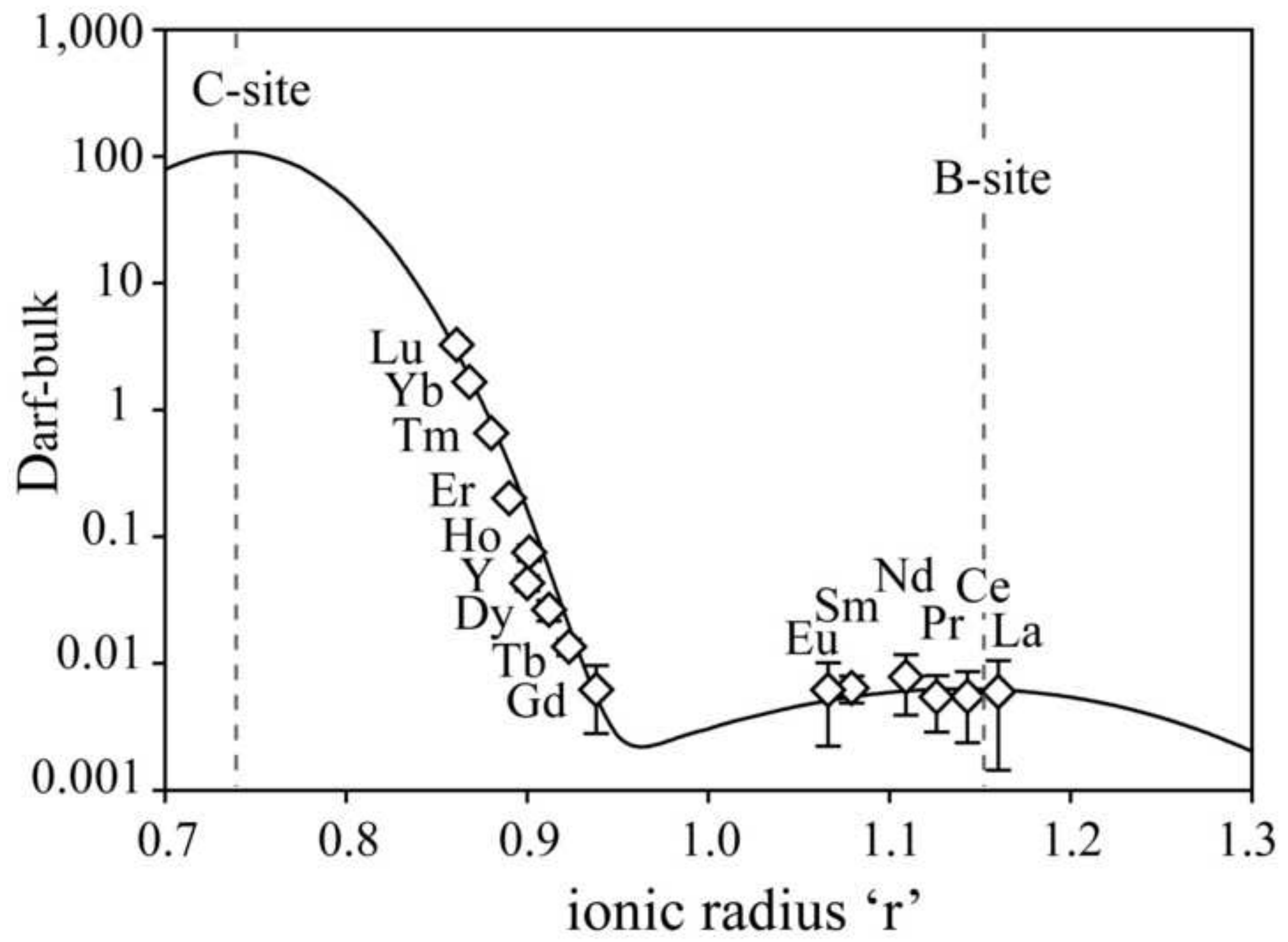

Siegel K, Williams-Jones AE, van Hinsberg VJ (2017) The amphiboles of the REE-rich A-type peralkaline Strange Lake pluton fingerprints of magma evolution. Lithos 288:156-174.

doi: 10.1016/j.lithos.2017.07.012. 


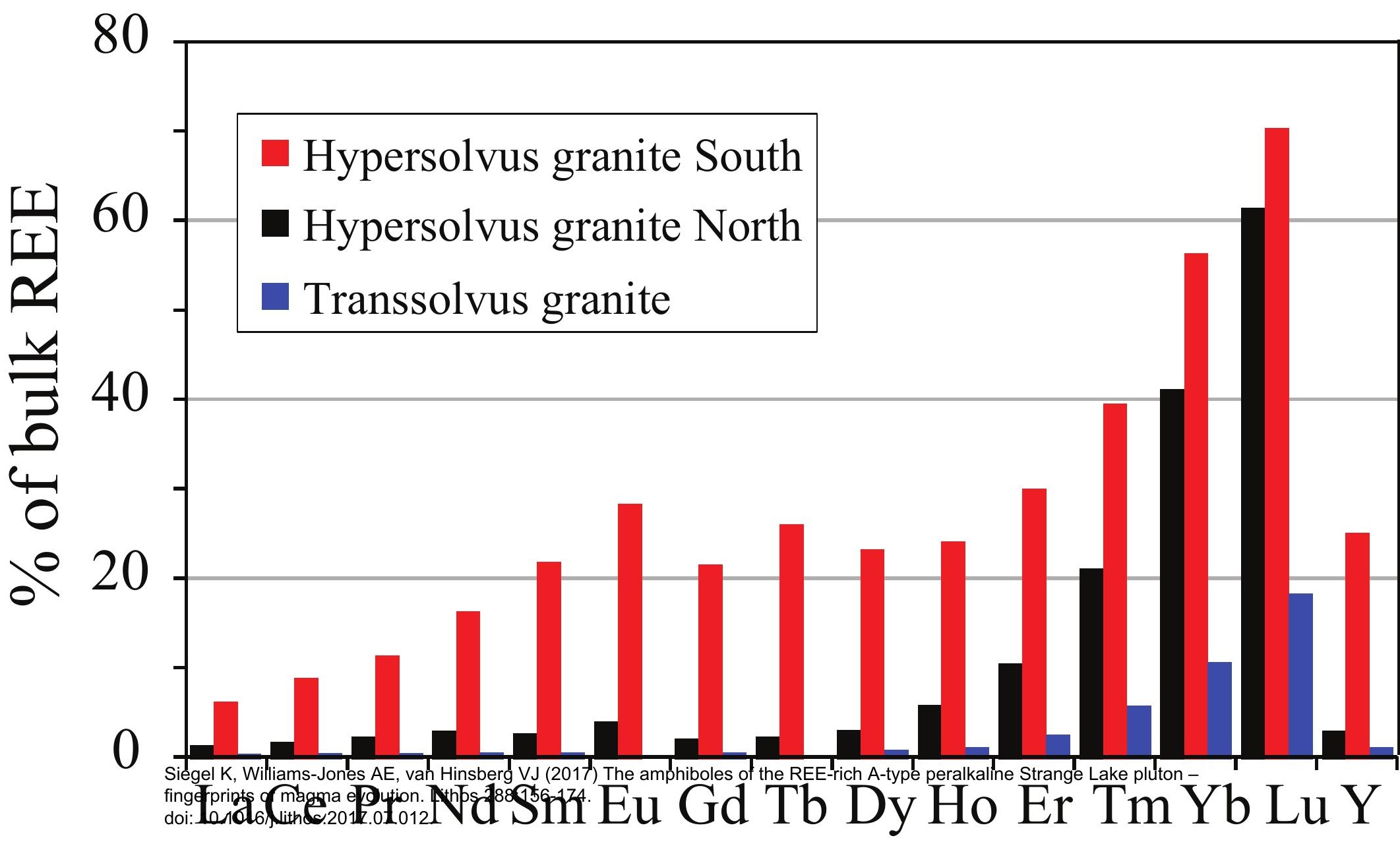




\section{a) Hypersolvus granite}

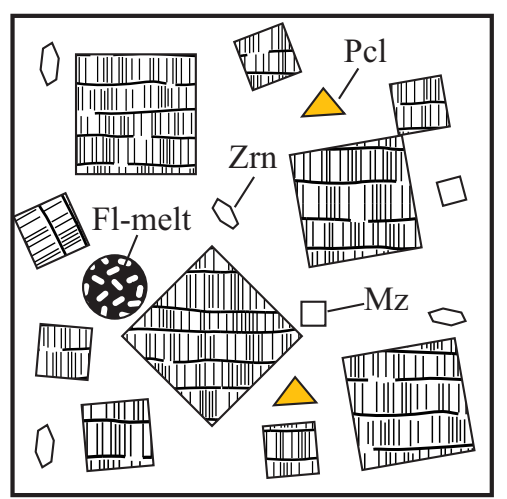

Liquidus (magma chamber)

$\mathrm{T} \geq 700{ }^{\circ} \mathrm{C}$

$\mathrm{P}>2$ kbar

fO2 low (QIF - QFM)

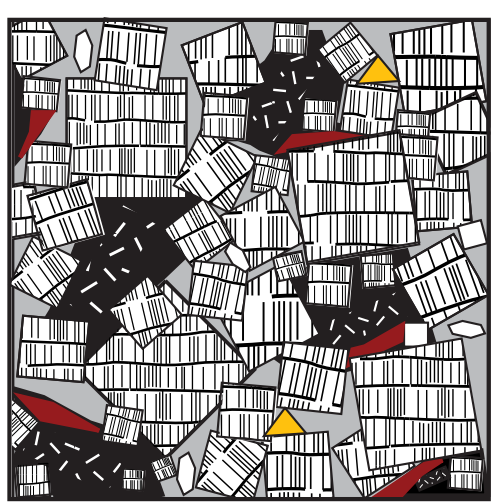

Solidus (after emplacement)

$\mathrm{T} \sim 700-660{ }^{\circ} \mathrm{C}$

$\mathrm{P} \sim 1-2 \mathrm{kbar}$

$f \mathrm{O}_{2}$ intermediate $(<\mathrm{QFM})$

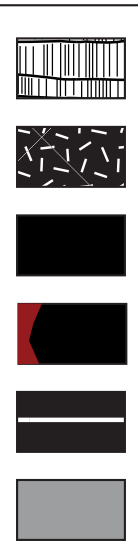

IIIIIII

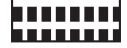

Na-alteration:

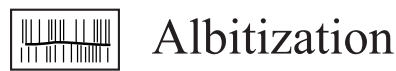

Quartz

Microcline

Perthitic alkali feldspar

Arfvedsonite - inclusion bearing

Arfvedsonite - late stage

Ti-Na-silicate replacement

Ferro-ferri-leakeite - phenocryst

Albite

\section{b) Transsolvus granite}

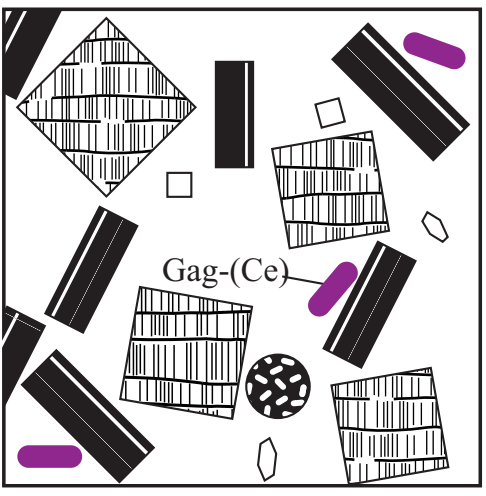

Liquidus (magma chamber)

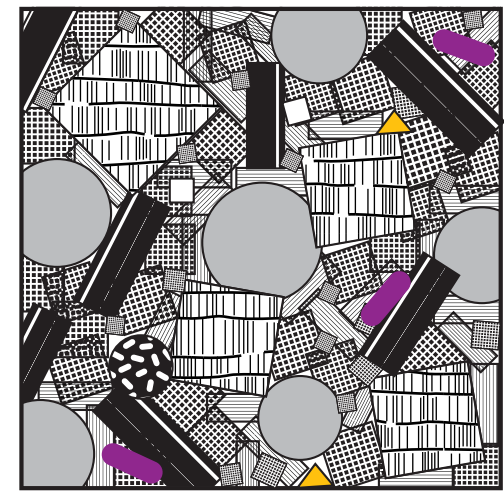

Solidus (after emplacement)

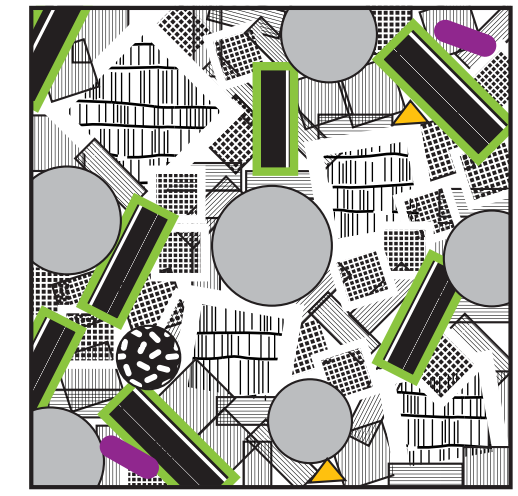

Subsolidus (Na-alteration)

$\mathrm{T} \sim 450-350{ }^{\circ} \mathrm{C}$

$\mathrm{T}<700^{\circ} \mathrm{C}$

$\mathrm{T}<700-550{ }^{\circ} \mathrm{C}$

$\mathrm{REE}-$-rith 2 A-kbpar eralkaline Strange Lake pluton -

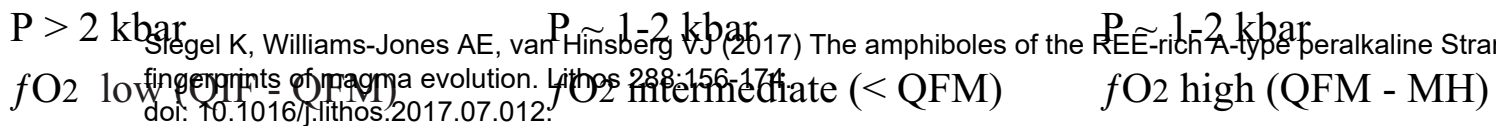


